Portland State University

PDXScholar

6-6-2019

\title{
Scenes from the Swale: Investigating Spatial and Temporal Dimensions of Nitrogen Cycling in Urban Stormwater Bioretention Facilities
}

Erin Nicole Looper

Portland State University

Follow this and additional works at: https://pdxscholar.library.pdx.edu/open_access_etds

Part of the Biogeochemistry Commons, and the Water Resource Management Commons Let us know how access to this document benefits you.

Recommended Citation

Looper, Erin Nicole, "Scenes from the Swale: Investigating Spatial and Temporal Dimensions of Nitrogen Cycling in Urban Stormwater Bioretention Facilities" (2019). Dissertations and Theses. Paper 5497. https://doi.org/10.15760/etd.7372

This Dissertation is brought to you for free and open access. It has been accepted for inclusion in Dissertations and Theses by an authorized administrator of PDXScholar. Please contact us if we can make this document more accessible: pdxscholar@pdx.edu. 
Scenes from the Swale: Investigating Spatial and Temporal Dimensions of Nitrogen Cycling in Urban Stormwater Bioretention Facilities

by

Erin Nicole Looper

A dissertation submitted in partial fulfillment of the requirements for the degree of

Doctor of Philosophy

in

Earth, Environment and Society

Dissertation Committee:

Jennifer L. Morse, Chair

Anna-Louise Reysenbach

Kevan Moffett

Olyssa Starry

Portland State University

2019 
(C) 2019 Erin Nicole Looper 


\begin{abstract}
Urban development is transforming landscapes at unprecedented rates. Human activities and landscape modifications associated with urbanization extensively increase hydrologic demands and modify natural hydrologic systems; consequently, population growth occurring in urban areas increases pressure on water resources. Urban aquatic ecosystems are vulnerable to impacts associated with increased connectivity with urban surfaces and hydrologic changes that initiate long-term changes in receiving waterbodies. Nitrogen $(\mathrm{N})$ loading from urban and suburban catchments to receiving surface waters can lead to impairment of aquatic ecosystems and is a concern in many cities with water quality issues. To improve urban water quality, cities are increasingly adopting the use of bioretention facilities (BRFs), systems that are designed to imitate natural hydrological and ecological processes, in an attempt to mitigate adverse impacts of urban hydrology on developed sites and provide additional ecosystem services. Among the desired functions of BRF, nutrient cycling and pollutant removal are important services for water quality.
\end{abstract}

While many ecological functions of BRFs remain poorly understood, there is growing interest among researchers in examining the capacity of BRFs to provide $\mathrm{N}$ removal processes. Denitrification is of particular interest as it is the only permanent pathway for ecosystem $\mathrm{N}$ removal. High potential for $\mathrm{N}$ removal via denitrification and other $\mathrm{N}$ cycling processes has been observed, however, there have been limited on-theground assessments of how $\mathrm{N}$ cycling processes in BRFs vary across different seasonal conditions and regional climates. The objective of this dissertation is to provide a detailed 
assessment of soil $\mathrm{N}$ process rates and variability in BRFs across seasons and geographic contexts in the United States.

Chapter 2 presents a survey of $\mathrm{N}$ cycling in BRFs in Portland, OR, across seasons and examines the influence of soil drainage properties of these processes. Chapter 3 expands the spatial dimension and compares seasonal $\mathrm{N}$ cycling in BRFs in Baltimore, MD, and Portland, OR, to capture how these processes vary in distinct seasonal and regional conditions. Chapter 4 further broadens the spatial scope and examines $\mathrm{N}$ cycling in BRFs in 6 US cities and compares BRF soils to reference riparian areas to determine how similar BRF systems are to the ecosystems after which they are designed.

The results from this dissertation showed that seasonal variability was not a primary influence on $\mathrm{N}$ cycling rates. $\mathrm{N}$ cycling rates showed some variability across regions, but signatures of the soil ecology in individual BRFs were similar across regions and distinct from natural riparian areas. These results also suggest that there may be important tradeoffs in the ecosystem services provided by BRFs, and that designers should consider the priorities of the stormwater management programs in order to achieve a balance between these tradeoffs. This study is one of several that examines potential $\mathrm{N}$ cycling in BRFs, but it extends the temporal and spatial dimensions of this body of research, showing that the capacity of $\mathrm{N}$ cycling processes in BRFs does not change significantly across seasonal conditions but may be impacted by design and maintenance decisions across regions. Ultimately, providing hydrologic ecosystem services, such as high infiltration rates, and important nutrient cycling services like denitrification may require a balance between soil drainage rates that support stormwater 
volume mitigation while providing substantial enough retention times to support pollutant removal processes. 


\section{Dedication}

\section{I dedicate this work:}

To Di, Laura, and Annie, my first mentors in science, without whom I never would have started this journey.

To my husband, who graciously did the dishes while I wrote this dissertation. 


\section{Acknowledgements}

Throughout the research and writing of this dissertation, I received a great deal of support and assistance from mentors, colleagues, and funders. I would like to specifically acknowledge and thank my advisor, Dr. Jennifer L. Morse, for her mentorship, guidance, and support throughout this academic pursuit. She connected me to a broad network of opportunities and collaborators that I will carry on into the next phase of my career.

I would also like to acknowledge and thank my committee: Dr. Anna-Louis Reysenbach, Dr. Olyssa Starry, and Dr. Kevan Moffett. This interdisciplinary nature of this committee was challenging and pushed me to think critically and holistically at my research. Their varied expertise and perspectives were invaluable contributions to my work.

I would like to acknowledge and thank my colleagues in the ESUR IGERT for the rich discussions, brainstorms, and critiques that broadened my vision and understanding. Specifically, I want to extend a very special thank you to my collaborator and friend, Marissa Matsler who traveled to the ends of the country with me in pursuit of the swale.

Finally, I would like to acknowledge the funding sources, without whom this work would not have been possible. This work was supported by the National Science Foundation IGERT grant \# 0966376: “Sustaining Ecosystem Services to Support Rapidly Urbanizing Areas." Additionally, this work was supported by the National Science Foundation Urban Resilence to Extremes Sustainability Research Network and the Edward D. and Olive C. Bushby Scholarship at Portland State University. 


\section{Table of Contents}

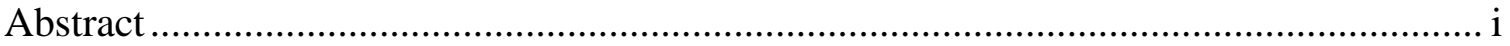

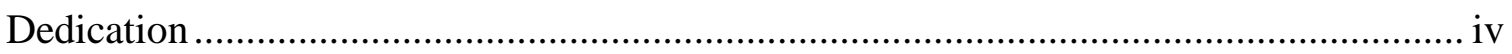

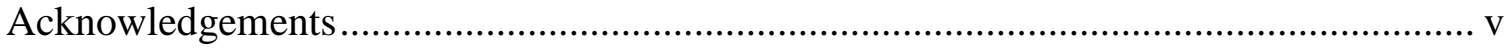

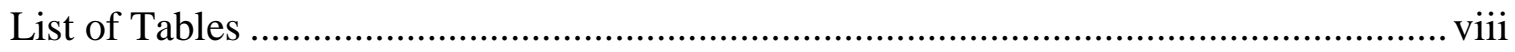

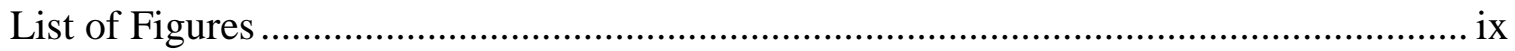

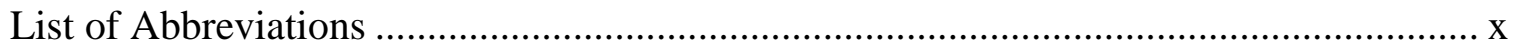

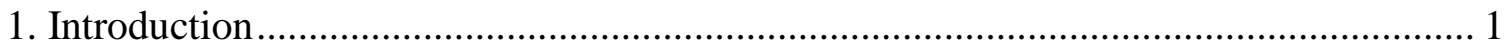

1.1 Urban Stormwater Management ...................................................................... 1

1.2 The role of the nitrogen cycle in BRFs .................................................... 10

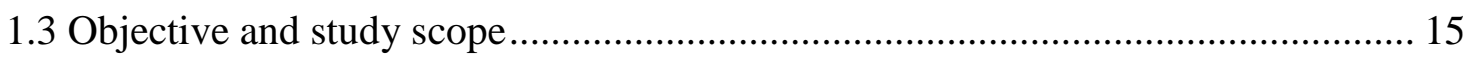

2. Seasonal and Environmental Controls on Nitrogen Cycling and Potential Nitrogen Removal in Stormwater Bioretention Facilities....................................................... 18

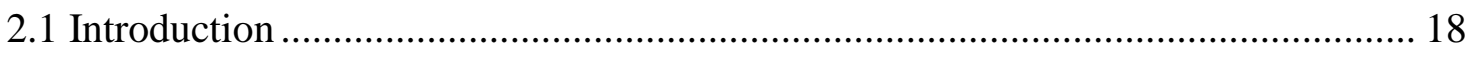

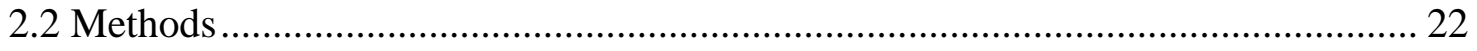

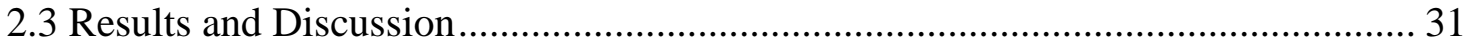

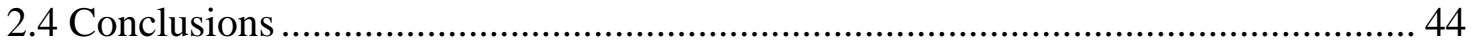

3. Seasonal and Regional Variability in Nitrogen Cycling Processes in Urban

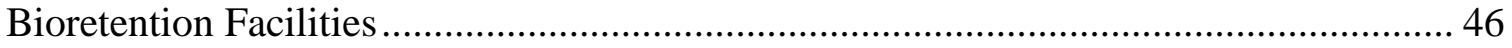

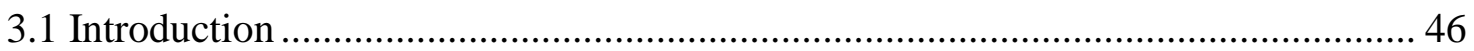

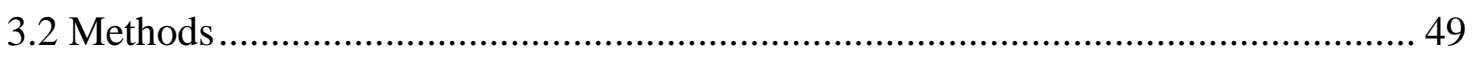

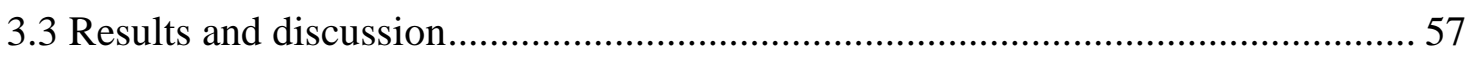

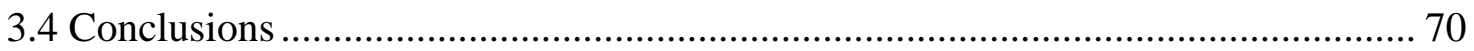

4. Multi-City Comparison of Soil bio-physiochemical properties and Nitrogen Cycling in Stormwater Bioretention Facilities in the United States............................................. 72

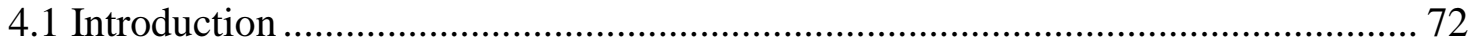

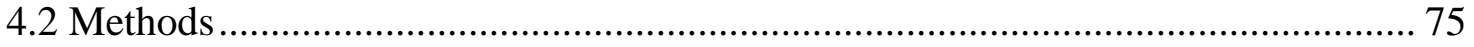

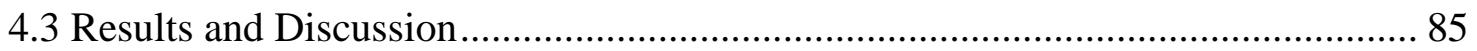




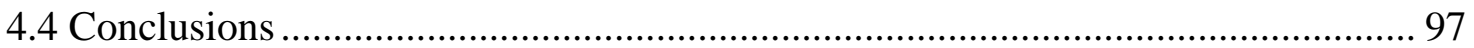

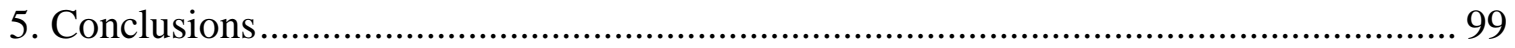

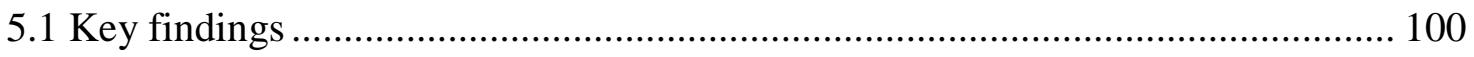

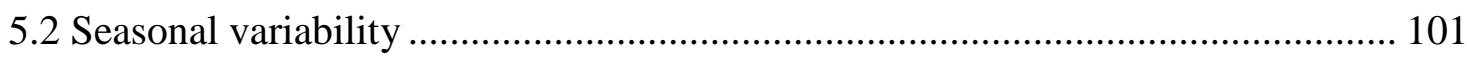

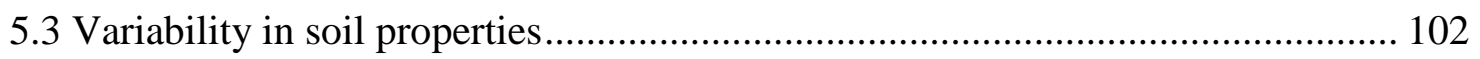

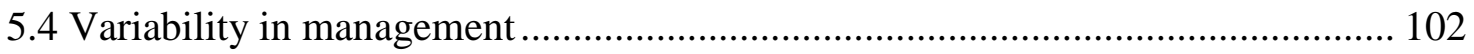

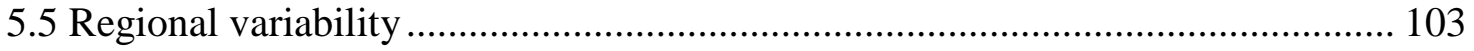

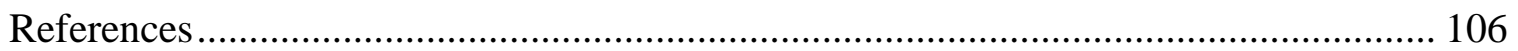

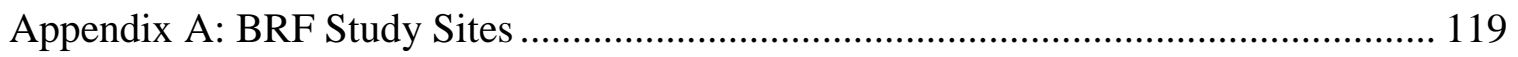

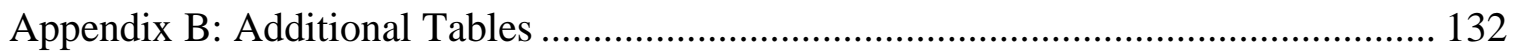




\section{List of Tables}

Table 1.1. Ecosystem services in ecologically based stormwater systems............ 4

Table 1.2. General components of bioretention and bioinfiltration design............. 7

Table 2.1. Study site characteristics of bioretention sites in Portland, OR............. 25

Table 2.2. Drainage and soil particle size in bioretention sites in Portland, OR........ 32

Table 2.3. Potential nitrogen cycling rates in bioretention sites in Portland, OR....... 36

Table 2.4. Potential nitrogen removal efficiency in bioretention sites in Portland, OR.. 42

Table 3.1. Average soil properties in bioretention sites in Baltimore and Portland...... 59

Table 3.2. Statistical results assessing the effects of and interaction between city and season on soil properties ............................................... 59

Table 3.3. Average $\mathrm{N}$ cycling rates in bioretention sites in Baltimore and Portland.... 61

Table 3.4. Statistical results assessing the effects of and interaction between city and

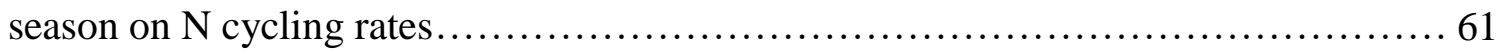

Table 3.5. Multiple linear regression model results comparison................... 62

Table 4.1. Cities, source of reference riparian areas, and climate in study locations.... 77

Table 4.2. Soil bio-physiochemical properties in bioretention sites................ 88

Table 4.3. Soil $\mathrm{N}$ cycling rates in bioretention sites............................ 88

Table 4.4. Soil bio-physiochemical properties in LTER sites................... 93

Table 4.5. Soil $\mathrm{N}$ cycling rates in LTER sites.............................. 93

Table 4.6. Analysis of similarity results for paired bioretention-riparian comparisons.. 96 


\section{List of Figures}

Figure 1.1. Generalized cross section of a bioretention facility $\ldots \ldots \ldots \ldots \ldots \ldots \ldots \ldots \ldots$

Figure 1.2. Hypothesized ecological trajectories of processes in bioretention facilities.... 9

Figure 1.3. Simplified conceptual model of the soil nitrogen cycle.................. 12

Figure 2.1 Location of study................................................. 22

Figure 2.2. Temperature and precipitation patterns in Portland, OR................. 24

Figure 2.3. Soil inorganic nitrogen patterns.................................... 33

Figure 2.4. N cycling rates and soil moisture patterns............................. 37

Figure 2.5. Coefficients of variation for each variable........................... 39

Figure 3.1. Location of study sites......................................... 50

Figure 3.2. 30-year average annual precipitation patterns in Baltimore and Portland.... 51

Figure 3.3. Average monthly temperature and antecedent precipitation in study sites... 52

Figure 3.4. N cycling rates in Baltimore and Portland............................ 60

Figure 4.1. Location of study sites....................................... 78

Figure 4.2. 10-year average daily temperature and precipitation in study sites..........79

Figure 4.3. N cycling rates in bioretention sites............................... 87

Figure 4.4. NMDS plot of bioretention soil ecological fingerprints..................94

Figure 4.5. NMDS plot of bioretention and riparian soil ecological fingerprints........95 


\section{List of Abbreviations}

\begin{tabular}{|c|c|}
\hline BLT & Baltimore, MD \\
\hline $\mathrm{BRF}$ & Bioretention Facility \\
\hline CLT & Charlotte, NC \\
\hline CWA & Clean Water Act \\
\hline DEA & Potential Denitrification \\
\hline GSI & Green Stormwater Infrastructure \\
\hline $\mathrm{N}$ & Nitrogen \\
\hline $\mathrm{NH}_{4}^{+}$ & Ammonium \\
\hline $\mathrm{N}_{\min }$ & Potential Net Nitrogen Mineralization \\
\hline $\mathrm{N}_{\text {nit }}$ & Potential Net Nitrification \\
\hline $\mathrm{NO}_{3}^{-}$ & Nitrate \\
\hline NPDES & National Pollutant Discharge Elimination System \\
\hline NYC & New York City, NY \\
\hline PDX & Portland, OR \\
\hline PHX & Phoenix, AZ \\
\hline Resp & Respiration \\
\hline SOM & Soil Organic Matter \\
\hline SYR & Syracuse, NY \\
\hline
\end{tabular}




\section{Introduction}

\subsection{Urban Stormwater Management}

Urbanization is the most rapidly occurring form of land use change across the globe, transforming landscapes at unprecedented rates (Grimm et al. 2008). Urban growth has a disproportionate impact on global processes, with development occurring on less than $3 \%$ of the global terrestrial surface but impacting ecosystems worldwide (Grimm et al. 2008, Seto et al. 2011). The increasingly urban nature of the global population has numerous implications for the integrity and functioning of environmental systems across the globe (Grimm et al. 2008; Wu 2008). Anthropogenic activities significantly increase hydrologic demands and modify natural hydrologic systems; consequently, population growth occurring in urban areas increases pressure on water resources. Hydrologic connections between terrestrial and aquatic systems are simultaneously increased and lost as a result of urban land use change: increased impervious area, subsequent reductions in vegetation, and stormwater drainage systems collectively increase the connectivity between uplands and adjacent surfaces waters, leading to the delivery of large volumes of runoff to receiving water bodies, and decrease the connectivity between landscape surfaces and groundwater since infiltration is inhibited by these watershed modifications (Leopold 1968, Hollis 1975, USEPA 2002; Kaushal and Belt 2012).

Urban aquatic ecosystems are vulnerable to impacts associated with increased connectivity with urban surfaces, which leads to hydrologic changes that initiate longterm changes in receiving waterbodies (Booth 1990). Consequently, waterbodies draining urban landscapes experience changes in hydrology, water quality, channel morphology, 
ecology, and a reduced ability to process and adapt to the increasing changes within the channel (Walsh et al. 2005). The Clean Water Act (CWA) of 1972 initiated a regulatory framework to guide protective and restorative practices in urban and suburban watersheds through the National Pollutant Discharge Elimination System (NPDES). The NPDES program addresses drivers of aquatic impairment by regulating point sources that discharge to surfaces waters. In urban areas, point source runoff sites include combined sewer systems (collects stormwater runoff, domestic sewage, and industrial wastewater into one pipe and discharges directly to surface waters during large precipitation events) and multiple separate storm sewer systems (stormwater runoff collection system discharging to surface waters). Urban areas are required to control point source contributions from these sources, including the volume and quality of water being discharged to surface waters (National Research Council 2009). In addition to pointsource runoff from pipes, urban areas contribute distributed, non-point source runoff directly from impervious surfaces. Consequently, urban areas are challenged with developing management solutions to control point- and nonpoint-source surface runoff and mitigate the damaging environmental and economic effects of urban stormwater (Walsh et al. 2005).

Urban stormwater management has shifted from narrowly-focused approaches that exclusively targeted flooding reduction to an integrative, multi-objective approach that considers multiple goals in design and decision-making (Chocat et al. 2001; Wong 2006; Fletcher et al. 2015). Programs under the CWA support and advocate the use of restored and engineered ecosystems to accomplish stormwater mitigation goals, with the 
expectation that they may provide ecosystem functions, services, and benefits (Costanza et al. 1997; De Groot et al. 2002; MEA 2005) to the same degree as natural ecosystems (e.g. wetland mitigation in Section 404 of the CWA) (Cole and Shafer 2002). Ecosystembased management strategies for stormwater control have been shown to provide ecosystem services to urban areas including climate and temperature regulation, biodiversity, carbon sequestration, water quality improvement, and socio-cultural benefits (Table 1.1), that may or may not be provided to the same extent as in equivalent natural areas (Moore and Hunt 2012).

Ecologically-based approaches to urban stormwater management are broadly classified by many terms that vary based on local and regional perspectives and contexts. Terms such as low impact development (Department of Environmental Resources 1999), sustainable urban drainage systems (CIRIA 2000), water sensitive urban design (Wong 2006), best management practices (Schueler 1987), stormwater control measures (National Research Council 2009), among other terms, are used to describe holistic approaches to urban stormwater management. Green stormwater infrastructure (GSI) is a term used to describe the broad set of structural stormwater management methods that utilize vegetated systems to deliver desired ecosystem services (Fletcher et al. 2015). Municipalities are increasingly adopting the use of GSI to manage stormwater by intercepting runoff before it reaches receiving water bodies (Kambites and Owen 2006; Carter and Fowler 2008; Amati and Taylor 2010) for the provision of stormwater benefits, in addition to the delivery of additional ecosystem services and the perception as an urban amenity (Tzoulas et al. 2007). 
Table 1.1. Ecosystem services that are or may be provided by ecosystem-based stormwater management (Adapted from MEA 2005; De Groot 2006).

\begin{tabular}{|c|c|c|}
\hline $\begin{array}{l}\text { Ecosystem } \\
\text { Service Category }\end{array}$ & $\begin{array}{l}\text { Ecosystem } \\
\text { Service }\end{array}$ & Description \\
\hline \multirow[t]{5}{*}{$\begin{array}{l}\text { Regulating } \\
\text { services }\end{array}$} & Hydrologic & $\begin{array}{l}\text { Flooding reduced through regulating runoff volume and/or peak } \\
\text { runoff rates; may also increase groundwater recharge }\end{array}$ \\
\hline & Water quality & $\begin{array}{l}\text { Sediment, excess nutrients, pathogens, and other contaminant } \\
\text { loadings in runoff reduced through combination of physical, } \\
\text { chemical, and biological processes }\end{array}$ \\
\hline & $\begin{array}{l}\text { Greenhouse } \\
\text { gas regulation }\end{array}$ & $\begin{array}{l}\text { Atmospheric } \mathrm{CO}_{2} \text { removed by vegetation and is subsequently re- } \\
\text { released through microbial respiration or stored through burial and } \\
\text { sediment accretion. Methane and other greenhouse gases may be } \\
\text { generated }\end{array}$ \\
\hline & Air quality & $\begin{array}{l}\text { Air quality may be improved through filtration and/or absorption } \\
\text { of particulates, NOx, and other air contaminants by vegetation and } \\
\text { soils }\end{array}$ \\
\hline & Climate & $\begin{array}{l}\text { More favorable microclimate may be maintained through direct } \\
\text { shading and/or evapotranspirative heat dissipation }\end{array}$ \\
\hline \multirow[t]{2}{*}{$\begin{array}{l}\text { Provisioning } \\
\text { services }\end{array}$} & Raw material & $\begin{array}{l}\text { Vegetation can be harvested and used as raw material for } \\
\text { composting, ornamental purposes, or other beneficial uses }\end{array}$ \\
\hline & Food & $\begin{array}{l}\text { Many edible plants can be supported by ecologically-based } \\
\text { stormwater systems and could be harvested as a food resource }\end{array}$ \\
\hline \multirow[t]{3}{*}{ Cultural services } & Recreation & $\begin{array}{l}\text { Areas can be used for alking/jogging, wildlife viewing, and other } \\
\text { recreational pursuits }\end{array}$ \\
\hline & Education & $\begin{array}{l}\text { Physical, chemical, and biological processes and structure of } \\
\text { systems can be studied and used to enhance educational programs }\end{array}$ \\
\hline & Aesthetic & $\begin{array}{l}\text { Vegetation and open water areas are known to provide soothing } \\
\text { benefits, to promote health and well-being, and to provide a sense } \\
\text { of beauty to observers }\end{array}$ \\
\hline $\begin{array}{l}\text { Supporting } \\
\text { services }\end{array}$ & $\begin{array}{l}\text { Nutrient } \\
\text { cycling }\end{array}$ & $\begin{array}{l}\text { Transformation, retention, and attenuation, of organic and } \\
\text { inorganic nutrients in runoff }\end{array}$ \\
\hline $\begin{array}{l}\text { Biodiversity } \\
\text { services }\end{array}$ & Biodiversity & $\begin{array}{l}\text { May contribute to biological and genetic diversity through habitat } \\
\text { provision for plants, microorganisms, invertebrates, and } \\
\text { vertebrates }\end{array}$ \\
\hline
\end{tabular}

GSI is implemented as a complement to larger-scale stormwater programs to substitute for natural ecosystem functions that have been lost with development. GSI is designed to imitate natural hydrological and ecological processes by infiltrating, detaining, storing, evaporating, and filtering local runoff to achieve predevelopment 
hydrology on developed sites (Dietz et al. 2007; Cizek and Hunt 2013). In contrast to single-purpose gray stormwater infrastructure (piped drainage and treatment systems) that are designed solely to move stormwater off urban surfaces, GSI is designed to reduce and treat stormwater within the urban landscape, potentially offering additional ecosystem services by providing environmental, social, and economic benefits (Portland Stormwater Management Manual 2016).

GSI comprises a variety of different types of structures that range in design and landscape features, including porous pavement, underground filters, green roofs, basins, infiltration facilities, swales, among other types (McPhillips and Matsler 2018). Many of these classification categories are further divided into multiple sub-classifications that range in hydrologic properties and design characteristics. For example, extended detention structures (dry with intermittent flooding) and retention ponds (permanently wet) are both classified within the basin category, and wet swales and dry swales are classified as swales (Bell et al. 2016; McPhillips and Matsler 2018). Due to the range and variability of characteristics, features, and functions pooled together within these categories, these classifications may be overlapping, contradicting, arbitrary, and may not be fully representative of the constituent structures within categories. Moreover, naming conventions and vernacular surrounding GSI classification is not consistent throughout the literature or across jurisdictional boundaries (Fletcher et al. 2015).

In North America, bioretention, and related bioinfiltration, are one of the most commonly used types of GSI. The designs of bioretention and bioinfiltration facilities are similar across all aspects, except that bioinfiltration facilities do not feature an underdrain 
that collects water and conveys it to the storm sewer network or receiving stream (Hunt et al. 2012). The function of retention in GSI is distinct from the function of detention. Detention structures collect and temporarily hold stormwater runoff during storm events before slowly discharging to receiving streams or water bodies, thereby mitigating peak discharge and providing potential pollutant and sediment removal through increased residence time. Stormwater retention structures fully mitigate stormwater runoff from entering surface waters by means of infiltration or discharging to the stormwater sewer and treatment system (Cizek and Hunt 2013; McPhillips and Walter 2015).

This dissertation focuses on bioretention facilities (BRFs) (bioretention and bioinfiltration designs) that receive runoff from adjacent impervious surfaces, do not receive piped runoff, and host vegetated soil systems that are intermittently dry between precipitation events. BRFs in this dissertation were classified as green streets, bioswales, dry swales, stormwater planters, rain gardens, infiltration basins, and stormwater basins depending on the location (city) of the sites. The differences between these structural distinctions are nuanced, and the sites in this study have a basic design of surface vegetation, a growing medium (prepared soil mixture), gravel, and an underdrain or overflow discharge mechanism if the underlying soil does not meet infiltration standards (Table 1.2; Figure 1.1) (Portland Stormwater Management Manual 2016). These general design features are intended to be reflective of conditions present in a natural riparian area (Groffman et al. 2003). 
Table 1.2. General components of bioretention and bioinfiltration design (from Hunt et al. 2012).
Bioretention Component
Description

Ponding zone

The surface-ponding zone. Depth and volume must be specified.

Fill medium

An engineered fill medium with moderately high permeability. Depth, composition, and infiltration rate must be specified.

Root zone

Upper layer of the media available to the plant roots. Water stored in this region is available for both evapotranspiration and exfiltration.

Lower media zone

Lower media layer not readily available to roots. Water stored in this region is released through exfiltration.

Underdrain
(bioretention only)

Typically small-diameter $(100-150 \mathrm{~mm})$, plastic pipes. These drainage lines are located in the gravel layer below the fill medium to collect water and convey it to the storm sewer network or receiving stream. Underdrains are most often used when bioretention cells are located in slowly draining soils and are required when impermeable liners are used. Can be constructed with gate valves when soil conditions are marginally permeable. Underdrains should be below the root zone to prevent clogging.

Internal water storage

A subsurface portion of the medium that provides additional storage volume in the bioretention cell. In permeable soils, water stored in this layer is principally released through exfiltration. The internal water storage layer is created by elevating the exit of the underdrain. 


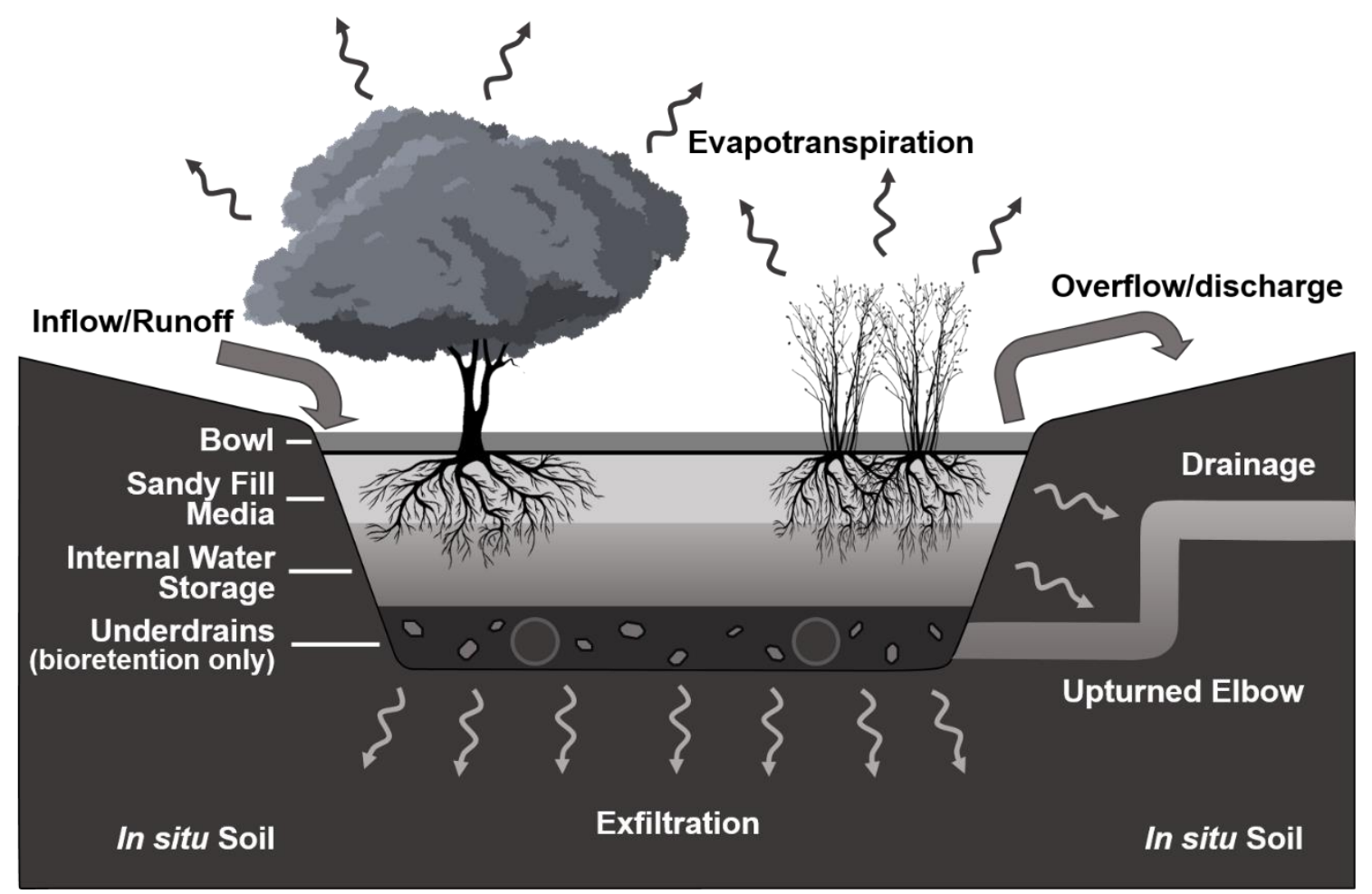

Figure 1.1. Generalized cross section of a BRF (modified from Hunt et al. 2012).

BRF designs are intended to imitate functions of natural riparian ecosystems as a technological solution to replace the functions provided by aquatic systems that are lost or modified by urban development. Municipalities develop standards for these ecologically-based stormwater facilities with guidelines regarding the appropriate soil fill medium, sizing requirements, and plant palette. Specific guidelines which vary spatially and temporally direct the decisions for site design, and stormwater management requirements change across space and through time, potentially leading to a high degree of heterogeneity in BRFs across cites (Portland Stormwater Management Manual 2016). Although BRF designs are modeled after natural ecosystems such as riparian zones that provide infiltration, detention, storage, evaporation, and filtration of local runoff (Dietz et al. 2007), BRF ecosystems are unlike these natural analogs in many ways: BRFs are 
engineered and constructed, isolated in the environment, experience more frequent and intense flooding events, receive supplies of organic and inorganic pollutants in urban runoff, and are designed and implemented in similar ways across regions (Groffman et al. 2003; Palmer et al. 2014). As such, BRF ecosystems may have different ecological trajectories from their natural analogues (Figure 1.2).

a) ECOLOGICAL CONVERGENCE

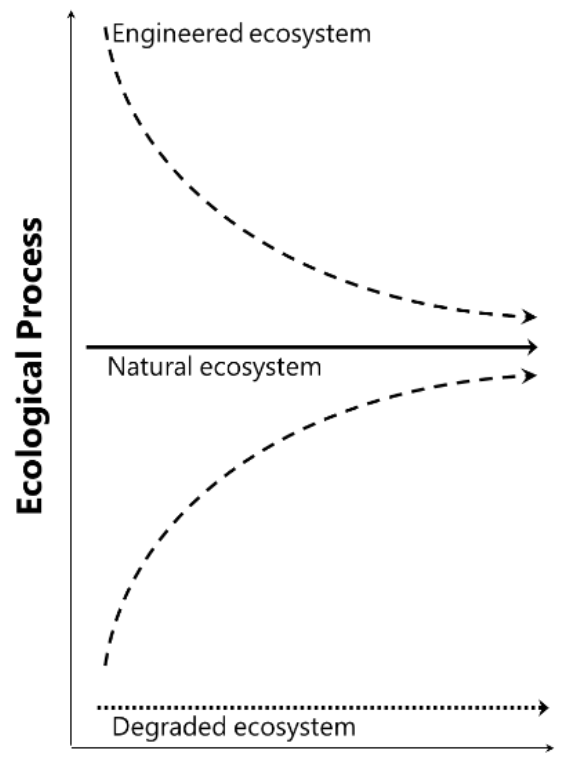

Time b) ECOLOGICAL DIVERGENCE

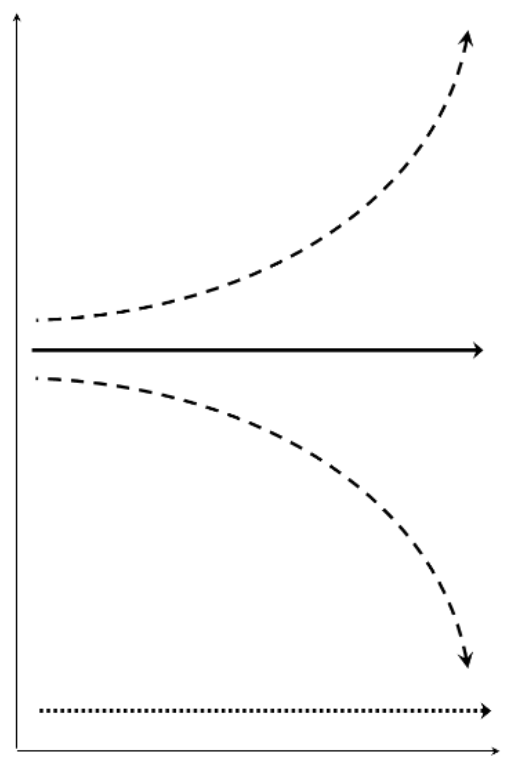

Time

Figure 1.2. Hypothesized ecological trajectories of processes within BRFs relative to natural landscape features, such as riparian areas. Solid lines represent the hypothesized state of an ecological process in an undisturbed, natural ecosystem. The dotted line represents the hypothesized state of an ecological process in a degraded ecosystem relative to its undisturbed state. The dashed lines represent four possible trajectories of ecological processes in engineered ecosystems relative to the natural ecosystems after which they are designed and the degraded ecosystems from which they were restored.

For example, ecosystem functions and processes may initially be more similar to the degraded ecosystems from which they were restored (e.g. impervious surface, compacted soils), but through time the trajectory of this ecosystem process may become more similar to the natural ecosystem after which the BRF was modeled (Figure 1.2a). Alternatively, 
BRF ecosystems may initially operate in a similar capacity as the natural ecosystem, but due to the factors that distinguish these systems (BRFs are isolated, have constructed hydrology, receive urban pollutants), through time, they may evolve to function more similarly to the degraded ecosystem from which they were restored (Figure 1.2b). Consequently, there are uncertainties about the development of ecosystem function and services in BRFs, the stability of BRF ecosystem structure and function, how design choices impact BRF ecosystem processes, and the influence of external factors such as management and maintenance on BRF function (Pataki et al. 2011).

BRFs are landscaped for stormwater functionality and aesthetic benefits. Landscape plans are designed to include vegetation that facilitates sedimentation and pollutant filtration, integrates with other landscaped projects, provides wildlife habitat, improves site aesthetics, and improves project marketability. Vegetation must tolerate fluctuating soil moisture, from inundated to desiccated conditions, and native and nonnative species are selected from an approved plant list. As a result of these broad vegetative requirements, a wide variety of plant palettes appear in GSI to address various functional and aesthetic goals (Portland Stormwater Management Manual 2016).

\subsection{The role of the nitrogen cycle in BRFs}

Anthropogenic activities are now introducing more reactive $\mathrm{N}$ annually than natural processes (Galloway et al. 1995), as $\mathrm{N}$ is mobilized from long-term storage pools through human activities, primarily through the use of $\mathrm{N}$ fertilizers, biomass burning, and land cover change (Khalil and Rasmussen 1992). These alterations to the $\mathrm{N}$ cycle have 
consequently led to increasing quantities of biologically available $\mathrm{N}$ forms, which, as an often-limiting nutrient, affects biological systems across levels of organization and spatial scales (Vitousek 1994; Hamilton et al. 2001; Rablais et al. 2002). Urbanization has been shown to have a significant impact on the $\mathrm{N}$ cycle (Kaye et al. 2006), as the delivery of urban point- and nonpoint-sources of degraded water quality to streams has increased $\mathrm{N}$ mobilization and transport, and the capacity of streams draining urbanized catchments to retain and remove $\mathrm{N}$ has decreased (Grimm et al. 2005). Many municipalities with water quality issues are concerned with nitrogen $(\mathrm{N})$ loading from urban and suburban catchments to receiving surface waters that leads to impairment of these aquatic ecosystems (Bernhardt et al. 2008).

As a result of increased $\mathrm{N}$ mobilization in urban watersheds, $\mathrm{N}$ retention within these catchments is a priority when managing landscapes enriched with N. Denitrification is one of the key processes in the biogeochemical $\mathrm{N}$ cycle and is the most important permanent sink for $\mathrm{N}$ in terrestrial and aquatic ecosystems as it eliminates $\mathrm{N}$ from subsequent downstream transport (Howarth et al. 1996; Hamilton et al. 2001) (Figure $1.3)$. 


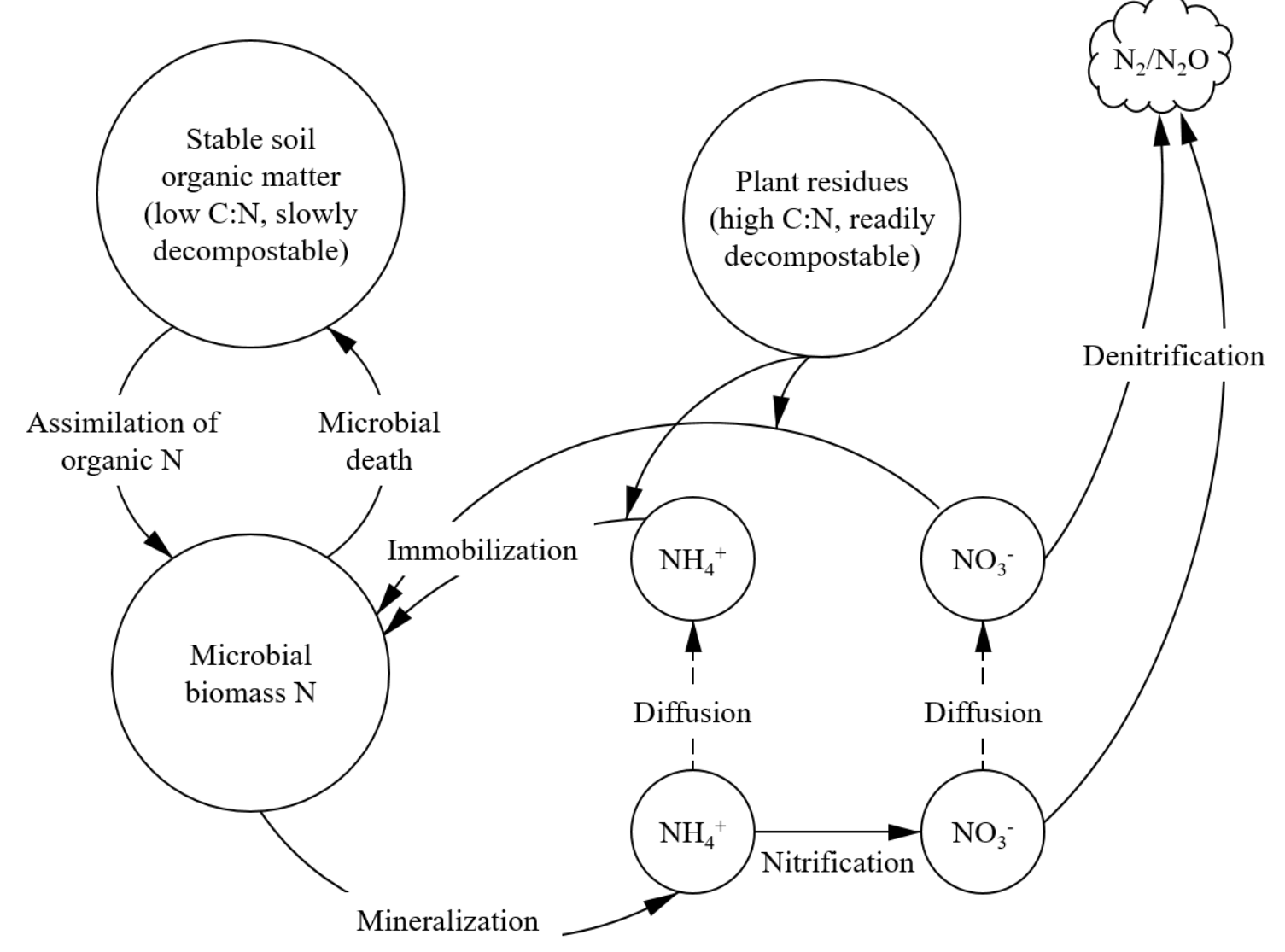

Figure 1.3. Simplified conceptual model of the soil nitrogen cycle. (Adapted from Drury 1991).

The primary goal of engineered GSI is to collect and manage volumes of stormwater, and, as a result, the net effects of design decisions are reflected in the hydrology of the facility (Davis et al. 2011; Bell et al. 2016). In particular, a BRFs capacity to detain or retain a given volume of runoff is the critical design goal. Sites are designed so that particular sized storms will be attenuated within a given time frame (Portland Stormwater Management Manual 2016). The rate at which water moves through a soil profile is the net result of the depth and intensity of precipitation and the 
hydraulic conductivity of the soil matrix (McDonnell 1990). These hydrologic properties control ecosystem processes within BRFs, particularly parameters that are sensitive to soil oxygen concentrations, such as denitrification. The rate at which water leaves a facility (through infiltration and overflow) determines whether and for how long the soils are saturated following a rain event, thereby affecting soil redox conditions.

Environmental redox conditions play key roles in microbially-mediated transformations of organic and inorganic compounds (electron donors) and humic substrates, metals, and other electron acceptors and controls the release or sequestration of these materials (Reddy and D'Angelo 1997). In the absence of oxygen, denitrification is a heterotrophic respiration process in which $\mathrm{NO}_{3}{ }^{-}$is used as the electron acceptor (when the more thermodynamically favorable $\mathrm{O}_{2}$ is not available). The metabolic response in the environment to these controllers is largely dependent on characteristics of the microbial community (Knowles 1982).

The heterogeneity of vegetation in BRFs may play a role in soil biogeochemical outcomes. Plant diversity has been shown to influence microbial community function and has the potential to change the functional capacity of denitrifiers. Denitrification is directly controlled by oxygen $(\mathrm{O})$, nitrate $\left(\mathrm{NO}_{3}^{-}\right)$, and carbon $(\mathrm{C})$, and since plants and microorganisms do not compete for $\mathrm{NO}_{3}{ }^{-}$at the organismal level (Groffman 1988), the relationship between vegetation and microbial denitrification is mediated through the regulation of soil $\mathrm{O}$ and $\mathrm{C}$ by plants. These relationships may play a different role across climates that experience different seasonal dynamics that influence growing season characteristics, particularly in non-wetland ecosystems in which soil moisture is closely 
related and sensitive to precipitation. Because BRF hydrology resembles riparian floodplains that are periodically inundated following precipitation and high flow events, hydrologic differences may have importance consequences for the dominant environmental factors that regulate and control denitrifying communities. Thus, denitrification is highly spatially and temporally variable.

In this project, potential denitrification, measured as denitrification enzyme activity (DEA), is used as an integrative measure of denitrification capacity (Bettez and Groffman 2012). The assay integrates long-term variability in the controlling factors in the denitrification process by removing limitations to the reaction. Addition of $\mathrm{NO}_{3}$ - and labile $\mathrm{C}$ in the DEA assay removes any $\mathrm{N}$ or $\mathrm{C}$ limitations within the soil microbial community, allowing for the characterization of differences among sites independent of $\mathrm{NO}_{3}$ - and DOC concentrations. Additionally, forced anaerobiosis in the incubation chamber catalyzes the initiation of anaerobic respiration. Because DEA is used in tandem with the acetylene inhibition method and negates many of the usual limitations of this method. With added $\mathrm{C}$ and $\mathrm{NO}_{3}-, \mathrm{NO}_{3}-$ limitations are removed, and the effect of $\mathrm{C}_{2} \mathrm{H}_{2}$ on nitrification is negligible. As such, DEA rates represent the functional capacity of denitrifiers by measuring the maximum potential for denitrification and do not represent in situ denitrification rates, allowing for a robust comparison across time and a range of environmental conditions (O'Connor et al. 2006). The existing microbial community reflects the recent history of environmental conditions which has shaped the current community composition. A change in DEA over time can indicate a change in microbial community function in response to changes in the environment (McGill 2010). This is a 
useful comparative tool for different ecosystem types when frequent sampling is not possible (Bettez and Groffman 2012). This method is ideal for investigating the environmental controls on denitrification to understand how particular (selected) attributes of the ecosystem affect $\mathrm{N}$ removal via denitrification.

Additional $\mathrm{N}$-transforming processes that regulate the presence and transformation of $\mathrm{N}$ from organic forms present in plant and detrital materials into ammonium $\left(\mathrm{NH}_{4}{ }^{+}\right)$and $\mathrm{NO}_{3}{ }^{-}$, including potential net mineralization and potential net nitrification (Robertson and Groffman 2015), were also investigated in this study to further determine how site variables and environmental conditions impact soil $\mathrm{N}$ dynamics.

\subsection{Objective and study scope}

To date, many studies have evaluated the hydrological performance of GSI (Hunt et al. 2006, Dietz et al. 2008, Bell et al. 2016); however, fewer studies have assessed the ecological functions within end-of-pipe GSI [e.g. stormwater control measures (SCMs) constructed wetlands, bioretention, wet and dry ponds; Stanley 1996, Zhu et al. 2004, Bettez and Groffman 2012]. Several recent studies have specifically investigated N cycling in GSI. Zhu et al. (2004) measured potential denitrification in urban retention basins in Phoenix, AZ and found much higher denitrification rates in these basins than the surrounding desert ecosystem. They found high rates of nitrification that were correlated to soil organic matter, but no relationship between SOM and DEA was observed, and no differences in $\mathrm{N}$ transformations were observed across GSI. Bettez and 
Groffman (2012) compared potential denitrification in prevailing end-of-pipe GSI in Baltimore County, MD to natural riparian zones, and found that end-of-pipe GSI function as hotspots for denitrification with higher potential denitrification relative to natural riparian zones. Using isotopic methods in biofiltration mesocosms, Payne et al. (2014) found that plant uptake is the primary fate for $\mathrm{NO}_{3}{ }^{-}$under typical stormwater concentrations, but denitrification increased with nitrate loading and played a greater role in mesocosms with plant species that are less effective at $\mathrm{NO}_{3}{ }^{-}$uptake. Chen et al. (2013) directly examined the microbial community related to $\mathrm{N}$ cycling in bioretention cells and found that a correlation between the abundance of denitrification genes and inundation time. Morse et al. (2017) compared $\mathrm{N}$ cycling dynamics in wet and dry basins over a one year study period and found that wet basins were capable of removing nearly $60 \%$ of dissolved inorganic $\mathrm{N}$ in stormwater runoff via denitrification, whereas dry basins only denitrified $1 \%$.

These studies have shown the high capacity for N removal in GSI, but most of these studies of ecology in GSI have focused on end-of-pipe structures such as wetlands, wet and dry basins or were laboratory-based mesocosm studies. There is limited information on the ecological performance of source-control GSI such as BRFs (curbside bioswales, stormwater planters, rain gardens). Additionally, many of these studies are temporally or spatially constrained and do not capture the dynamic and heterogeneous nature of the urban environment, such as the influence of site-level variations in design, variable weather patterns, climatological context, or differences in management. Studies with multiple temporal measurements observed processes multiple times within a single 
season (Morse et al. 2017), and studies with larger site counts have evaluated sites within a single city (Bettez and Groffman 2012) or region (Waller et al. 2018). As such, the goal of this research is to comprehensively assess the on-the-ground soil processes within BRFs across a variety of climatic and geographic contexts by characterizing soil $\mathrm{N}$ cycling in BRFs and evaluating how soil bio-physiochemical properties and processes vary across time and space. This research seeks to identify how seasonal variability and regional heterogeneity affect $\mathrm{N}$ cycling in BRF soils by assessing the relationships between driving factors and subsequent ecological function, starting at the site level and zooming out to the continental scale.

The first study in this dissertation examines site-level variability in BRF soil processes by evaluating soil bio-physiochemical properties and $\mathrm{N}$ cycling across seasonal wet and dry periods in Portland, OR, observing how these patterns vary in BRFs with different ranges of saturated hydraulic conductivity, and estimating the potential $\mathrm{N}$ removal capacities of BRFs across seasons. The second study in this dissertation examines temporal dynamics of soil processes in BRFs across regions by measuring soil bio-physiochemical properties and $\mathrm{N}$ cycling in sites in Baltimore, MD and Portland, OR during summer and winter conditions and determining how relationships between $\mathrm{N}$ cycling variables and environmental properties change across these contexts. The final study in this dissertation is a national-scale assessment of $\mathrm{N}$ cycling in BRFs, in which sites in Baltimore, MD, Charlotte, NC, New York City, NY, Phoenix, AZ, Portland, OR, and Syracuse, NY are assessed and compared across cities and relative to natural riparian area soils in these regions. 


\section{Seasonal and Environmental Controls on Nitrogen Cycling and Potential Nitrogen Removal in Stormwater Bioretention Facilities}

\subsection{Introduction}

Urbanization is a rapidly growing form of land use change occurring throughout the world (Grimm et al. 2008). In the United States, urbanization impacts more than $130,000 \mathrm{~km}$ of streams and rivers, resulting in impaired water quality across the country (USEPA 2000). To protect water quality, discharge of pollutants into surface waters is prohibited unless the discharge is permitted through the National Pollutant Discharge Elimination System (NPDES) under the Clean Water Act. Municipalities with stormwater NPDES permits are required to establish stormwater management programs that establish controls on post-development stormwater runoff (National Research Council 2009). Cities with combined sewer systems are regulated through NPDES wastewater permits, which limit and control the number of combined sewer overflow events (Tao et al. 2014). Portland, OR, has both types of NPDES permits and has developed a comprehensive stormwater management plan with goals to preserve and mimic the natural hydrologic cycle, minimize sewer system issues, and improve water quality (City of Portland 2016; Portland Stormwater Management Manual 2016). Mitigating peak storm discharge to surface waters is a primary concern due to urban development and combined storm-sanitary sewage systems. Onsite infiltration and flow control measures are prioritized to conserve the conveyance capacity of traditional stormwater infrastructure to comply with NPDES stormwater permit requirements (Portland Stormwater Management Manual 2016). 
Municipalities are increasingly adopting the use of green stormwater infrastructure (GSI) as a management strategy to mitigate the ecologically-damaging effects of urban stormwater (National Research Council 2009). The primary goal of engineered GSI is to collect and manage stormwater, and as a result, hydrologic characteristics of a facility are determined by design. In particular, infiltration-, retention-, and detention-based bioretention facilities (BRFs) are designed to infiltrate a given volume of runoff within a given time frame, for example 1 inch of rain within 24 hours (Portland Stormwater Management Manual 2016).

The rate at which water moves through a soil profile is the net result of the depth and intensity of precipitation and the hydraulic properties of the soil matrix (McDonnell 1990). These hydrologic properties also control ecosystem processes within BRFs that are influenced by soil moisture and oxygen content. Soil biogeochemical processes in particular are affected by the rate at which water leaves a facility (through infiltration, overflow, and evapotranspiration), which determines whether and for how long the soils are saturated following a rain event, thereby affecting soil oxygen dynamics and redox conditions (Reddy and D'Angelo 1997). Nitrogen (N) removal by microbial denitrification is one biogeochemical process that is highly sensitive to redox dynamics. $\mathrm{N}$ loading from urban and suburban catchments can lead to impairment of aquatic ecosystems draining urban catchments, thus denitrification in BRFs may be an ecological benefit to many municipalities with water quality concerns (Bernhardt et al. 2008).

With increasing prevalence of BRFs in urban areas to address water quality goals, understanding the nutrient transformation processes within these systems is an important 
component of quantifying the ecological benefits that they provide. Laboratory

mesocosm studies have generally reported high retention of sediment, heavy metals, and phosphorus $(\mathrm{P})$, however results concerning the removal potential of $\mathrm{N}$ have been more variable (Davis et al. 2001; Henderson et al. 2007; Fletcher et al. 2007; Hatt et al. 2008; Lucas et al. 2011; Norton et al. 2017). Investigations of BRF pollutant and nutrient removal efficacy at the field scale have shown moderate reductions in $\mathrm{P}$ and $\mathrm{N}$ concentrations during simulated storm events (49-90\%) (Hunt et al. 2003; Davis et al. 2006). Other studies have opened the black box of the processes that regulate these reductions in nutrients, $\mathrm{N}$ in particular, revealing a high potential for $\mathrm{N}$ removal via denitrification relative to natural riparian areas (Zhu et al. 2004; Bettez and Groffman 2012; Morse et al. 2017).

Although BRFs have the potential to increase $\mathrm{N}$ retention and removal via denitrification, field studies assessing the potential for $\mathrm{N}$ removal have not considered the seasonal or interannual variability of BRF, particularly in regions with seasonal climates (Zhu et al. 2004; Bettez and Groffman 2012; McPhillips and Walter 2015). Many studies have performed one-time assessments of soil ecological processes and did not take into account how these processes might change due to seasonal or annual fluctuations in environmental conditions such as seasonal precipitation or temperature patterns (e.g., Bettez and Groffman 2012, Payne et al. 2014, Zhu et al. 2004). A recent study by Morse et al. (2017) expanded the temporal scale of soil $\mathrm{N}$ patterns in BRF, but it was spatially limited, in that only four sites were included. Another recent study by Waller et al. (2018) considered an extensive number BRFs across the mid-Atlantic region but did not include 
effects of seasonality. The present study builds upon the growing body of work quantifying $\mathrm{N}$ cycling in BRFs and fills the gap between spatially extensive but temporally limited studies (Bettez and Groffman 2012, Waller et al. 2018) and temporally extensive but spatially limited studies (Morse et al. 2017) of N cycling in BRFs.

This study examines how patterns of $\mathrm{N}$ cycling in BRFs are influenced by variability in soil bio-physiochemical properties and seasonal conditions by examining potential soil $\mathrm{N}$ transformation rates during summer and winter to capture seasonal fluctuations in temperature and moisture conditions that are likely to affect soil $\mathrm{N}$ processes. The measurements included potential denitrification as determined by denitrification enzyme activity (DEA) assays, microbial biomass $\mathrm{N}(\mathrm{MBN})$, potential net nitrification $\left(\mathrm{N}_{\text {nit }}\right)$, potential net mineralization $\left(\mathrm{N}_{\min }\right)$, and a series of physiochemical parameters that influence microbial metabolic rates including soil inorganic $\mathrm{N}\left(\mathrm{NO}_{3}{ }^{-}\right.$and $\mathrm{NH}_{4}{ }^{+}$), soil moisture, soil organic matter content (SOM), and saturated hydraulic conductivity $\left(\mathrm{K}_{\mathrm{sat}}\right)$. The objective of this study was to determine how $\mathrm{N}$ cycling processes in BRFs change across conditions by assessing how DEA, $\mathrm{N}_{\min }$, and $\mathrm{N}_{\text {nit }}$ are affected by variability in soil bio-physiochemical properties and seasonal precipitation patterns. Specifically, the variability in potential $\mathrm{N}$ cycling rates across wet and dry seasons was examined across a range of drainage characteristics and compared to the potential to remove inorganic $\mathrm{N}$ (DIN) inputs across seasons. 


\subsection{Methods}

\section{Site description}

To characterize soil biogeochemistry under contrasting seasonal and hydrologic conditions, 9 curbside BRFs were sampled in summer and winter in Portland, OR, during July and December 2015 to assess the response of soil $\mathrm{N}$ cycling to seasonal variability in weather conditions. Portland's BRF program is extensive, with nearly 2500 facilities across the $376 \mathrm{~km}^{2}$ area of the city (Figure 2.1).

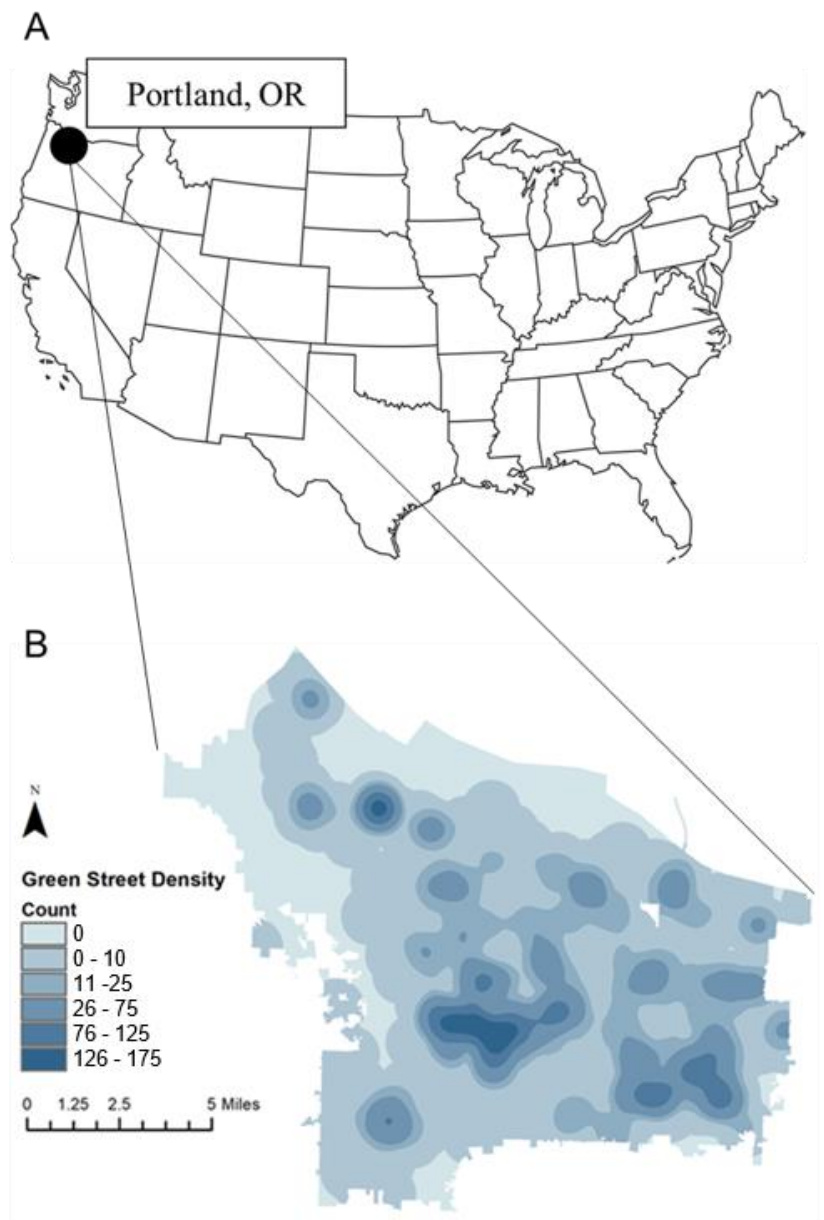

Figure 2.1. A) Location of study; B) Density of all BRFs in Portland, OR. 
Portland has characteristically warm, dry summers, with little to no rainfall occurring June-August (normal monthly cumulative precipitation $=43.2 \mathrm{~mm}, 16.5 \mathrm{~mm}$ and $17.0 \mathrm{~mm}$, respectively), and mild, wet winters that receive $>80 \%$ of annual rainfall (Figure 2.2; NCDC). Samples were collected within a two-week period in summer (July) and winter (December) in 2015 to capture the extremes of the climatic variability. Summer (June-August) 2015 was drier than average with $48.0 \mathrm{~mm}$ of rain. The months preceding winter sampling in 2015 (October-December) received $683.8 \mathrm{~mm}$ of rainfall, with $35.6 \%$ of annual precipitation occurring in December. December 2015 had historically high rainfall and is the wettest month to date in Portland with $419.6 \mathrm{~mm}$ of rain (11.03 $\mathrm{mm}$ above average).

BRFs in Portland predominantly comprise small-scale $\left(<100 \mathrm{~m}^{2}\right)$, curb-side structures that are designed to provide maximum runoff attenuation, based on Portland's 10-year design storm ( $86.4 \mathrm{~mm}$ of rainfall in 24 hours). Sites may be designed as basins, swales, curb extensions, or planters (collectively referred to as Green Streets) as outlined by specifications defined within the Portland Stormwater Management Manual. Sites vary in size, geometry, and site morphology, but utilize a standard soil media composition and vegetation palette (Portland Stormwater Management Manual 2016). We selected a variety of BRF facility types from multiple areas of the city to represent the heterogeneity of design, establishment date, and location of BRFs within the city. According to the descriptions in Bettez and Groffman (2012), their sites were either 
infiltration or extended dry basins, with the distinction being the presence or absence (respectively) of a subsurface liner beneath the BRF soil profile.
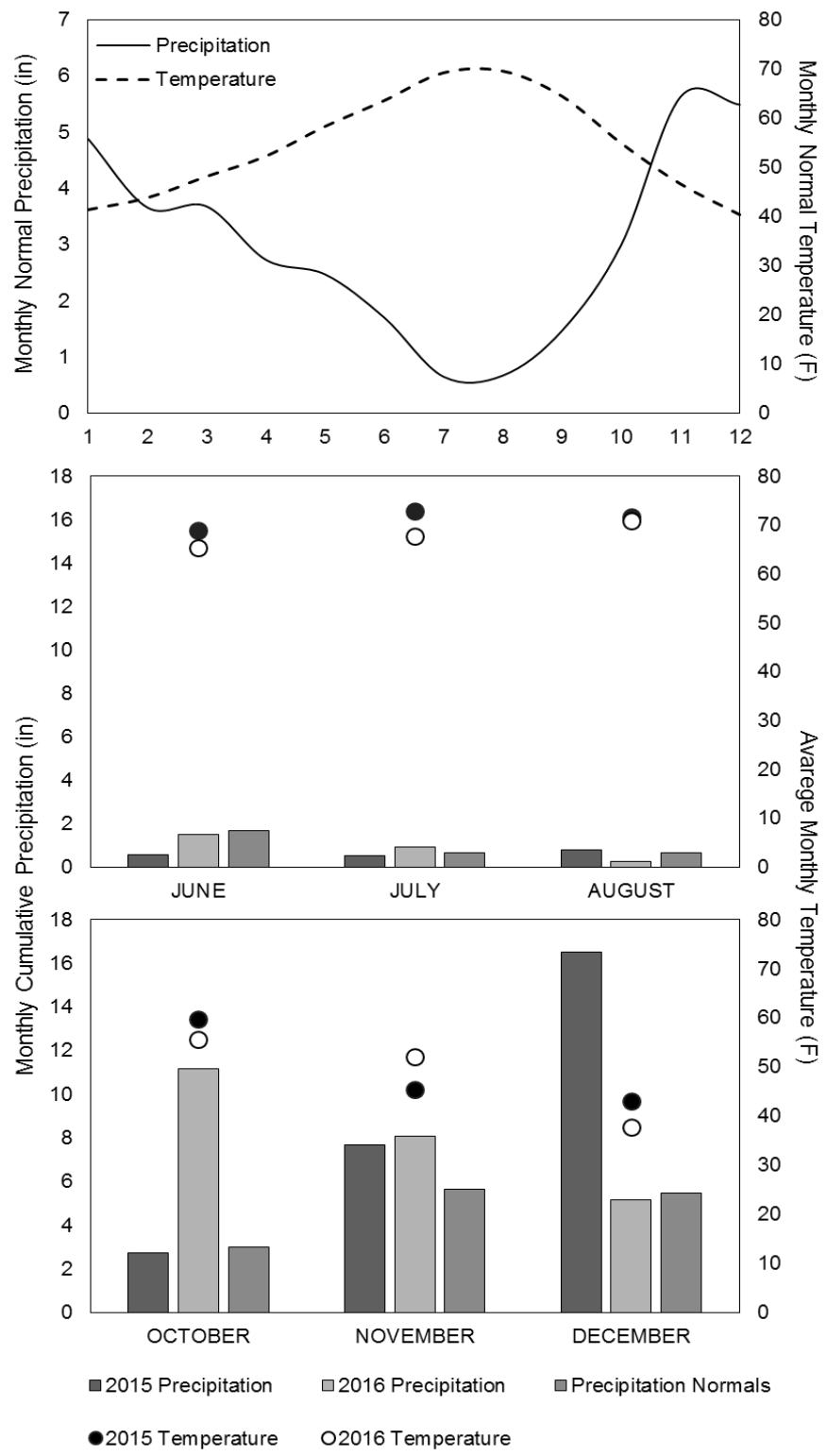

Figure 2.2. Temperature and precipitation patterns in Portland, OR. a) Average monthly precipitation and temperature (based on 30-year records; NCDC); b) Monthly cumulative precipitation and average monthly temperatures during summer sampling months in 2015 and 2016; c) Monthly cumulative precipitation and average monthly temperatures during winter sampling months in 2015 and 2016. 
Using soil saturated hydraulic conductivity $\left(\mathrm{K}_{\mathrm{sat}}\right)$ measured by the City of Portland's Bureau of Environmental Services (BES), we subdivided sites into low $(<250$ $\mathrm{mm} / \mathrm{hr}$ ) and high (>250 mm/hr) $\mathrm{K}_{\text {sat }}$ categories, as $\mathrm{K}_{\text {sat }}$ values of $250 \mathrm{~mm} / \mathrm{hr}$ and above behave similarly to a sand soil texture class (Rawls et al. 1982). K sat $_{\text {was determined }}$ through drawdown tests in which sites were inundated, and the change in surface water depth over time was recorded (BES 2013). Reported rates are minimum $\mathrm{K}_{\text {sat }}$ values that reflect long-term performance and are driven by the permeability and water holding capacity of subsurface soils (BES 2013). The BRF sites in our study received all inputs from surface runoff, drained catchments of similar urban-residential land use (primarily small-lot single-family homes), and were retrofit installations constructed between 2003 and 2013 (Table 2.1).

Table 2.1. Study site characteristics of bioretention facilities in Portland, OR.

\begin{tabular}{|c|c|c|c|c|c|c|}
\hline $\begin{array}{l}\text { Site } \\
\text { ID }\end{array}$ & $\begin{array}{c}\mathrm{K}_{\mathrm{sat}} \\
\text { Category }\end{array}$ & $\begin{array}{l}\text { Measured } \mathrm{K}_{\text {sat }} \\
\quad\left(\text { in } \mathrm{hr}^{-1}\right)\end{array}$ & $\begin{array}{c}\text { Year } \\
\text { Constructed }\end{array}$ & Type & $\begin{array}{c}\text { Basin Area } \\
\left(\mathrm{m}^{2}\right)\end{array}$ & $\begin{array}{l}\text { Drainage Area } \\
\qquad\left(\mathrm{m}^{2}\right)\end{array}$ \\
\hline NE-1 & $\mathrm{L}$ & 63.5 & 2003 & $\begin{array}{c}\text { Curb } \\
\text { extension }\end{array}$ & 30.10 & 432.00 \\
\hline SE-1 & $\mathrm{L}$ & 66 & 2010 & Swale & 46.54 & 159.05 \\
\hline SW-1 & $\mathrm{L}$ & 94 & 2005 & $\begin{array}{l}\text { Planter } \\
\text { Curb }\end{array}$ & 6.32 & 174.19 \\
\hline SE-2 & $\mathrm{L}$ & 121.9 & 2008 & extension & 19.32 & - \\
\hline $\mathrm{N}-1$ & $\mathrm{~L}$ & 223.5 & 2007 & Swale & 85.47 & 1114.84 \\
\hline $\mathrm{N}-2$ & $\mathrm{H}$ & 391.2 & 2010 & Planter & 4.46 & - \\
\hline $\mathrm{N}-3$ & $\mathrm{H}$ & 762 & 2008 & extension & 10.22 & - \\
\hline NE-2 & $\mathrm{H}$ & 1270 & 2009 & $\begin{array}{l}\text { Swale } \\
\text { Curb }\end{array}$ & 18.58 & 455.23 \\
\hline SW-2 & $\mathrm{H}$ & $>1270$ & 2009 & extension & 20.44 & 325.16 \\
\hline
\end{tabular}




\section{Field methods}

To capture the heterogeneity within each facility and the variability in soil conditions from inlet to outlet, 3 soil cores were collected along 4 transects (12 total cores per facility) to a depth of 6 inches $(15.24 \mathrm{~cm})$ using a 1 inch $(2.54 \mathrm{~cm})$ diameter nickelplated steel open-end soil probe (AMS Inc., ID) and combined into one Ziploc bag. The soil samples were kept on ice and immediately brought back to the laboratory where they were stored at $4^{\circ} \mathrm{C}$ until processing (within one week or less).

\section{Soil nitrogen cycling measurements}

Soils were homogenized by hand, and subsamples were analyzed for soil moisture, soil organic matter, microbial biomass $\mathrm{N}$, inorganic $\mathrm{N}\left(\mathrm{NH}_{4}{ }^{+}\right.$and $\left.\mathrm{NO}_{3}{ }^{-}\right)$, potential respiration, potential net nitrification $\left(\mathrm{N}_{\text {nit }}\right)$, potential net mineralization $\left(\mathrm{N}_{\min }\right)$, and potential denitrification (DEA).

Denitrification enzyme activity (DEA) was analyzed to determine potential soil denitrification rates, using the chloramphenicol-amended acetylene-block method (Tiedje et al. 1989). Triplicate soil slurries of $10 \mathrm{~g}$ soil and $10 \mathrm{~mL}$ DI water were amended with $\mathrm{NO}_{3}{ }^{-}$(as $\mathrm{KNO}_{3}$ ) and organic carbon (as dextrose) in $125 \mathrm{~mL}$ glass flasks capped with septa. We added chloramphenicol, an antibiotic that inhibits the production of new enzymes, allowing for denitrification rates measured in bottle assays to be more representative of denitrification activity at the time of sampling (Smith and Tiedje 1979). The flasks were purged with helium to remove oxygen and force anaerobiosis. We injected $5 \mathrm{~mL}$ of acetylene gas into the sealed, anoxic microcosms through septa caps 
using a syringe. Acetylene inhibits the conversion of nitrous oxide $\left(\mathrm{N}_{2} \mathrm{O}\right)$ to dinitrogen $\left(\mathrm{N}_{2}\right)$ by blocking the activity of nitrous oxide reductase, allowing the measurement of $\mathrm{N}_{2} \mathrm{O}$ accumulation to estimate denitrification rates.

Slurries were incubated at room temperature $\left(22^{\circ} \mathrm{C}\right)$ for 3 hours, and three $5-\mathrm{mL}$ gas samples were removed from the bottle headspaces at 45 -minute intervals during the incubation to measure $\mathrm{N}_{2} \mathrm{O}$ production over time. Flasks were continually mixed on a shaker table set at $125 \mathrm{rpm}$ between measurements to equilibrate $\mathrm{N}_{2} \mathrm{O}$ between the gas and aqueous phases. Gas samples were analyzed immediately by gas chromatography by manually injecting each sample directly into a Shimadzu GC-2014 equipped with a $2 \mathrm{~m}$ Porapak Q column and a ${ }^{63} \mathrm{Ni}$ electron capture detector. Concentrations were corrected for $\mathrm{N}_{2} \mathrm{O}$ solubility in the aqueous phase using the temperature-dependent Bunsen coefficient based on ambient laboratory temperature (Knowles 1979). The linear rate of $\mathrm{N}_{2} \mathrm{O}$ production was used to determine the rate of denitrification within each flask. Only time periods representing linear production of $\mathrm{N}_{2} \mathrm{O}$ were used for calculations due to potential interference of bottle effects (Groffman and Tiedje 1989). DEA rates were scaled to soil dry-mass (mg-N g-soil $\left.{ }^{-1} \mathrm{~h}^{-1}\right)$ to determine the flux of $\mathrm{N}$ per unit mass of soil, allowing comparisons across soils of contrasting physical properties.

Microbial biomass $\mathrm{N}$ was measured using the chloroform fumigation incubation method (Jenkinson and Powlson 1976). Samples were fumigated with chloroform to kill and lyse microbial cells (releasing cellular $\mathrm{N}$ ), and fumigated soils were inoculated with fresh $0.2 \mathrm{~g}$ soil. All fumigated and unfumigated control samples were incubated at $25^{\circ} \mathrm{C}$ in the dark for 10 days. During the incubation, microorganisms lysed by chloroform were 
mineralized $\mathrm{NH}_{4}{ }^{+}$. Prior to and following incubation, extractable $\mathrm{NH}_{4}{ }^{+}-\mathrm{N}$ and $\mathrm{NO}_{3}{ }^{-}-\mathrm{N}$ were measured in fumigated and control soil by incubating soil with $2.0 \mathrm{M} \mathrm{KCl}$ solution on a shaker table at $125 \mathrm{rpm}$ for one hour to release bound ions into solution. The supernatant was filtered through $2.5 \mu \mathrm{m}$ Whatman filters using gravimetric filtration. Soil extracts were analyzed for $\mathrm{NH}_{4}{ }^{+}$and $\mathrm{NO}_{3}{ }^{-}$on a SmartChem Analyzer (Unity Scientific, Milford, MA). The amount of $\mathrm{CO}_{2}$ and 2M KCl-extractable inorganic $\mathrm{N}$ produced in the fumigated soils during the incubation is proportional to the amount of $\mathrm{C}$ and $\mathrm{N}$ in the microbial biomass in the soil (using a correction factor of 0.41 ). The amount of $\mathrm{CO}_{2}$ produced in the unfumigated control samples was used to estimate microbial respiration. Inorganic $\mathrm{N}\left(\mathrm{NH}_{4}{ }^{+}\right.$and $\left.\mathrm{NO}_{3}{ }^{-}\right)$in pre- and post-incubation control soils were used to calculate potential net $\mathrm{N}_{\min }$ (production of inorganic $\mathrm{N}$ ) and $\mathrm{N}_{\text {nit }}\left(\right.$ transformation of $\mathrm{NH}_{4}{ }^{+}$ to $\mathrm{NO}_{3}{ }^{-}$via net change in $\mathrm{NO}_{3}{ }^{-}$).

\section{Soil characteristics}

We determined soil moisture using measuring gravimetric water content and drying subsamples at $105^{\circ} \mathrm{C}$ for 24 hours, and SOM by loss on ignition at $550^{\circ} \mathrm{C}$ for 4 hours. Soil $\mathrm{pH}$ was determined by equilibrating $15 \mathrm{~g}$ of soil with $30 \mathrm{~mL}$ DI water at room temperature for 30 minutes. Following equilibration, $\mathrm{pH}$ readings were taken from duplicate soil samples from each site using a Thermo Scientific Orion Star A111 pH benchtop meter (Thermo Fisher Scientific, Waltham, MA). 


\section{Particle size distribution}

Soil texture was analyzed using laser diffraction analysis. Soils were prepared by passing air-dried soil was through a $2.0 \mathrm{~mm}$ sieve. Particles $<2.0 \mathrm{~mm}$ were incubated with $100 \mathrm{~mL}$ of a $5 \%$ sodium hexametaphosphate (HMP) solution on a shaker table for 16 hours to deflocculate particles. Following deflocculation, soils were air-dried and subsampled ( $1 \mathrm{~g}$ ) for organic content removal via digestion with a $3 \%$ hydrogen peroxide solution $\left(\mathrm{H}_{2} \mathrm{O}_{2}\right) \cdot \mathrm{H}_{2} \mathrm{O}_{2}$ was added to the subsampled soils in increments of $2.5 \mathrm{~mL}$ to reach a total of $12.5 \mathrm{~mL}$. Digestions were incubated in a hot bath until completion. Samples were rehydrated with HMP solution, and sonicated for 5 seconds prior to analysis. Slurries were injected into a Becker Coulter LS 13320 Particle Sizing Analyzer to analyze particle distributions for particles between $0.001 \mathrm{~mm}-2.0 \mathrm{~mm}$. The resulting proportion of silts and clays were combined to produce the percent of fines (\% fines) present in each BRF soil. Additionally, the soil texture was assumed to be static across the two sampling intervals and was only measured on soil samples collected in winter 2015.

\section{Estimating potential $N$ removal}

Drawing from data provided in as-built reports for each facility provided by the contracted engineers and our measurements of potential denitrification in winter and summer, the potential removal of $\mathrm{N}$ from stormwater inputs was estimated using $\mathrm{Eq} 1$.
[Eq 1]:

$$
\% \mathrm{R}=(\mathrm{DEA} \times \mathrm{SA}) /(\mathrm{N} \times \mathrm{P} \times \mathrm{CA})
$$


Where:

- $\% \mathrm{R}$ is the potential proportion of $\mathrm{N}$ removed per season per facility

- DEA is the areal potential denitrification of each facility per season $\left(\mathrm{kg}-\mathrm{N} \mathrm{m}^{-2}\right)$

- $\mathrm{SA}$ is the soil surface area of each facility $\left(\mathrm{m}^{2}\right)$

- $\mathrm{N}$ is the estimated $\mathrm{N}$ concentration in stormwater runoff $\left(0.002 \mathrm{~kg}-\mathrm{N} / \mathrm{m}^{3}\right)$

- $\mathrm{P}$ is the total depth of precipitation per season $(\mathrm{m})$,

- $\mathrm{CA}$ is the contributing watershed area discharging into each facility $\left(\mathrm{m}^{2}\right)$

Some sites were built in tandem with additional cells to act as a treatment complex. In these cases, potential $\mathrm{N}$ removal was scaled to the treatment complex and corresponding contributing area. As-built reports were generated at the time of construction and created by various contracting firms, resulting in inconsistent reporting of design details across sites. While not all data was available for each facility, we provide a range in potential removal across the minimum and maximum values of the sampled sites.

\section{Statistical methods}

Due to the sample size and non-normality of the data, nonparametric tests were used for all analyses. For all $\mathrm{N}$ cycling parameters and soil moisture, a Scheirer-Ray-Hare test was performed with $\mathrm{K}_{\text {sat }}$ category and season as fixed factors. The Scheirer-Ray-Hare test is a nonparametric equivalent to a two-way ANOVA for a two-way factorial design $(\alpha=0.05)$. To compare the heterogeneity of variables across $K_{\text {sat }}$ categories, the coefficient of variation was calculated within $\mathrm{K}_{\text {sat }}$ categories for each variable. Statistical 
analyses were performed using the $\mathrm{R}$ statistical program (version 3.5.2; $\mathrm{R}$ Development Core Team, 2018).

\subsection{Results and Discussion}

The primary objective of this study was to identify how $\mathrm{N}$ cycling processes in BRFs change across seasons to determine what factors affect potential $\mathrm{N}$ cycling rates in BRFs. We sampled 9 BRFs in Portland, OR during summer and winter seasons and compared the variability in bio-physiochemical characteristics and potential $\mathrm{N}$ cycling among sites to determine how soil processes change under different seasonal conditions.

\section{Soil Characteristics}

Average soil characteristics varied among BRF sites (Table 2.2). Soil pH ranged from 6-7, which is consistent with Portland Stormwater Management Manual guidelines (Portland Stormwater Management Manual 2016). Soil moisture (measured as gravimetric water content) was similar among sites within seasons but showed significant seasonal differences: soils were drier in summer, with soil moisture ranging from 9.8 to $15.0 \%$ and wetter in winter, with soil moisture ranging from 20.9 to $45.3 \%$ (Figure 2.3; $\mathrm{p}=0.0011$ ). Particle size distribution was variable across sites, with median particle size (d50) ranging from 5.86 to $324.0 \mathrm{~mm}$ and percent fine particles ranging from 21.4 to $75.4 \%$.

Hydrology was distinctly different across sites, with $\mathrm{K}_{\text {sat }}$ ranging from $63.5 \mathrm{~mm} / \mathrm{hr}$ to rates that prevented ponding at the soil surface (BES 2013). $\mathrm{K}_{\text {sat }}$ rates ranged from 63.5 to $223.5 \mathrm{~mm} / \mathrm{hr}$ in the low $\mathrm{K}_{\text {sat }}$ category (L) and $391.2 \mathrm{~mm} / \mathrm{hr}$ to no ponding in the high 
$\mathrm{K}_{\text {sat }}$ category $(\mathrm{H}) . \mathrm{K}_{\text {sat }}$ measurements did not show a significant relationship to particle size variables.

Soil extractable inorganic $\mathrm{N}$ concentrations were variable but not significantly different between $\mathrm{K}_{\text {sat }}$ categories or seasons. Summer $\mathrm{NO}_{3}{ }^{-}$and $\mathrm{NH}_{4}{ }^{+}$concentrations ranged from 2.84 to $35.16 \mathrm{mg}-\mathrm{N} \mathrm{L}^{-1}$ and 2.50 to $10.88 \mathrm{mg}-\mathrm{N} \mathrm{L}^{-1}$, respectively, and winter

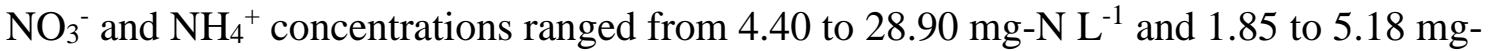
$\mathrm{N} \mathrm{L}^{-1}$, respectively (Figure 2.3).

Table 2.2. Soil saturated hydraulic conductivity ( $\mathrm{K}_{\text {sat }} ;$ BES measurements) and particle size distribution in bioretention sites in Portland, OR during the 2015 summer and winter sampling periods. $\mathrm{d} 50$ is the median particle diameter of a soil, and \% fines represents the total proportion of silts and clays in the soil.

\begin{tabular}{cccc}
\hline & & \multicolumn{2}{c}{ Particle Size Distribution } \\
\cline { 3 - 4 } Site ID & Ksat $(\mathrm{mm} / \mathrm{hr})$ & $\mathrm{d} 50(\mathrm{~mm})$ & $\%$ fines \\
\hline NE-1 & 63.5 & 5.9 & 75.4 \\
SE-1 & 30.5 & 275.5 & 28.2 \\
SW-1 & 94.0 & 51.6 & 53.1 \\
SE-2 & 121.9 & 69.6 & 48.5 \\
N-1 & 223.5 & 91.9 & 45.9 \\
N-2 & 391.2 & 324.0 & 21.4 \\
N-3 & 762.0 & 65.1 & 49.6 \\
NE-2 & 1270.0 & 300.9 & 22.2 \\
SW-2 & 1270.0 & 279.369 & 25.5 \\
\hline
\end{tabular}




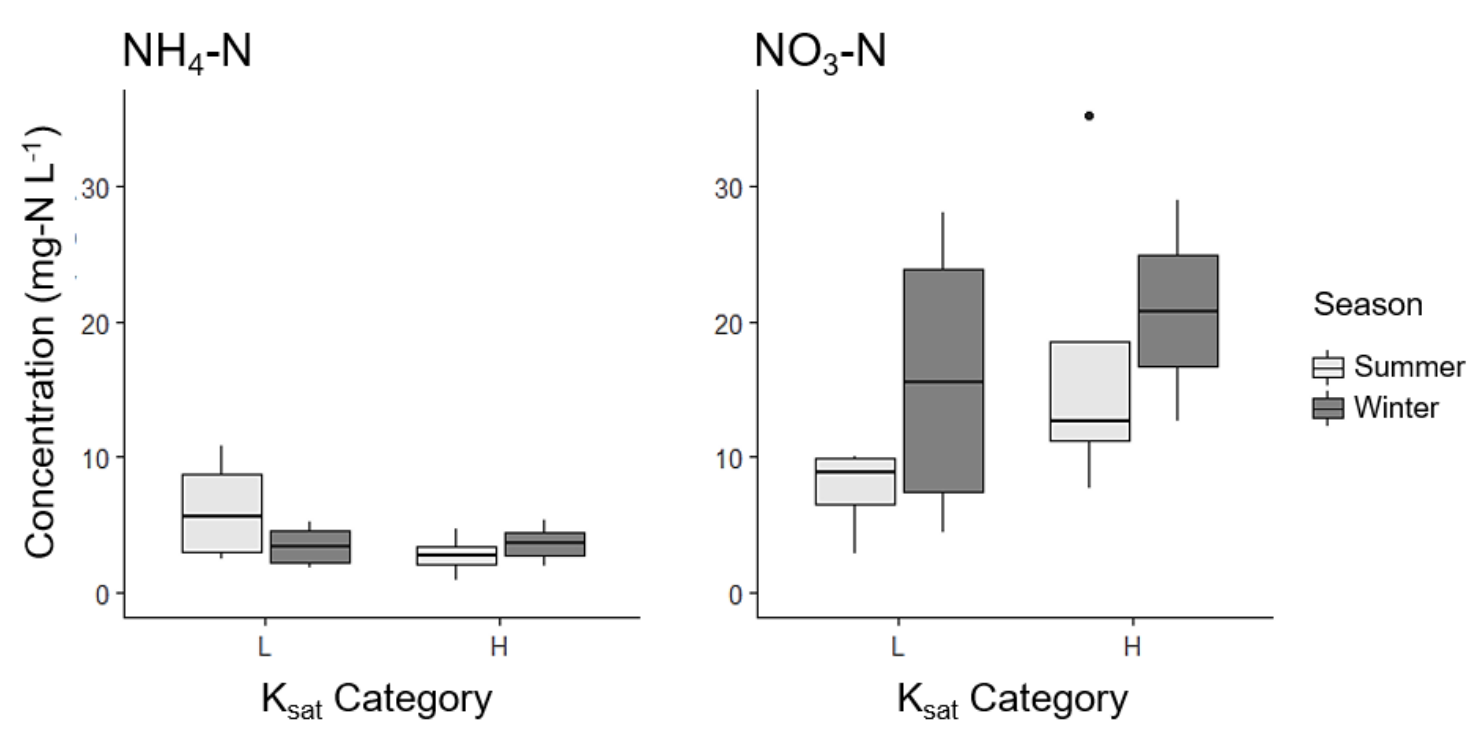

Figure 2.3. Soil extractable $\mathrm{NH}_{4}-\mathrm{N}$ and $\mathrm{NO}_{3}{ }^{-} \mathrm{N}$ concentrations by $\mathrm{K}_{\text {sat }}$ category during each sampling period. No significant differences were observed across categories.

\section{Soil N cycling}

Average $\mathrm{N}$ cycling rates ranged widely, but different $\mathrm{N}$ cycling variables followed similar patterns across $\mathrm{K}_{\mathrm{sat}}$ categories and seasons. Rates were generally significantly different between $\mathrm{K}_{\text {sat }}$ categories, with higher average rates occurring in slow-draining soils, and average $\mathrm{N}$ cycling rates were generally higher in winter than summer, however, no statistical differences occurred across seasons for any of the $\mathrm{N}$ cycling variables.

DEA rates were variable across sites, ranging from 0.16 to $0.92 \mathrm{ug}-\mathrm{N} \mathrm{g-soil}{ }^{-1} \mathrm{hr}^{-1}$. The range in DEA rates was similar across seasons with DEA with rates between 0.16 to 0.77 ug-N g-soil ${ }^{-1} \mathrm{hr}^{-1}$ in summer and 0.16 to $0.92 \mathrm{ug}-\mathrm{N}$ g-soil $^{-1} \mathrm{hr}^{-1}$ in winter. Average seasonal DEA rates were $0.31 \pm 0.22 \mathrm{ug}-\mathrm{N}$ g-soil ${ }^{-1} \mathrm{hr}^{-1}$ in summer and $0.46 \pm 0.30 \mathrm{ug}-\mathrm{N}$ g-soil ${ }^{-1} \mathrm{hr}^{-1}$ ) but were not significantly different across seasons. DEA rates were 
significantly different between $\mathrm{K}_{\text {sat }}$ categories, with higher DEA in slow-draining soils and lower DEA in fast-draining soils $(\mathrm{p}=0.046)$. While not significant, fast-draining soils demonstrated a difference in average DEA rates between summer and winter $(0.17 \pm$ 0.01 and $0.40 \pm 0.32$ ug-N g-soil ${ }^{-1} \mathrm{hr}^{-1}$, respectively) whereas slow-draining soils showed no difference between summer and winter $\left(0.46 \pm 0.25\right.$ and $0.54 \pm 0.32$ ug-N g-soil ${ }^{-1} \mathrm{hr}^{-1}$, respectively), however, results from the Scheirer-Ray-Hare test showed no significant interaction effect between season and $\mathrm{K}_{\text {sat }}$ category (Table 2.3).

$\mathrm{N}_{\text {nit }}$ and $\mathrm{N}_{\min }$ followed similar patterns to DEA in which summer rates ranged from -1.22-1.16 and -1.16-1.96 ug-N g-soil ${ }^{-1}$ day $^{-1}$, respectively, and winter rates ranged from -0.32-1.97 and -0.41 and 1.98 ug- $\mathrm{N}$ g-soil ${ }^{-1}$ day $^{-1}$, respectively. Average $\mathrm{N}_{\text {nit }}$ rates were $0.18 \pm 0.67$ ug- $\mathrm{N}$ g-soil ${ }^{-1}$ day $^{-1}$ in summer and $0.84 \pm 0.83$ ug-N g-soil ${ }^{-1}$ day $^{-1}$ in winter; average $\mathrm{N}_{\min }$ rates were $0.51 \pm 0.82 \mathrm{ug} \mathrm{N}$ g-soil ${ }^{-1}$ day $^{-1}$ in summer and $0.98 \pm 0.92$ ug-N g-soil ${ }^{-1}$ day $^{-1}$ in winter. As with DEA rates, soils with higher $\mathrm{K}_{\text {sat }}$ values demonstrated an observable but nonsignificant difference in $\mathrm{N}_{\text {nit }}$ and $\mathrm{N}_{\text {min }}$ rates between summer and winter, whereas soils with lower $\mathrm{K}_{\text {sat }}$ values did not show discernable differences between seasons. Sheirer-Ray-Hare tests confirmed that there was no interaction effect between season and $\mathrm{K}_{\text {sat }}$ category for $\mathrm{N}_{\text {nit }}$ or $\mathrm{N}_{\min }$ (Table 2.3).

Soil moisture did not show differences between $\mathrm{K}_{\text {sat }}$ categories but did differ significantly between seasons $(\mathrm{p}=0.0011)$, with drier soils in the summer and wetter soils in the winter (Figure 2.4). Soil moisture was predicted to be a regulating factor for $\mathrm{N}$ cycling, and we expected to see lower values occurring in drier soils in summer and higher values occurring in wetter soils in winter, particularly with DEA. $\mathrm{N}$ cycling results 
did not track closely with the patterns in soil moisture, and no significant differences

were observed in rates of $\mathrm{N}_{\min }, \mathrm{N}_{\text {nit }}$, and DEA between seasons despite the distinct pattern of dry soils in summer and wet soils in winter. 


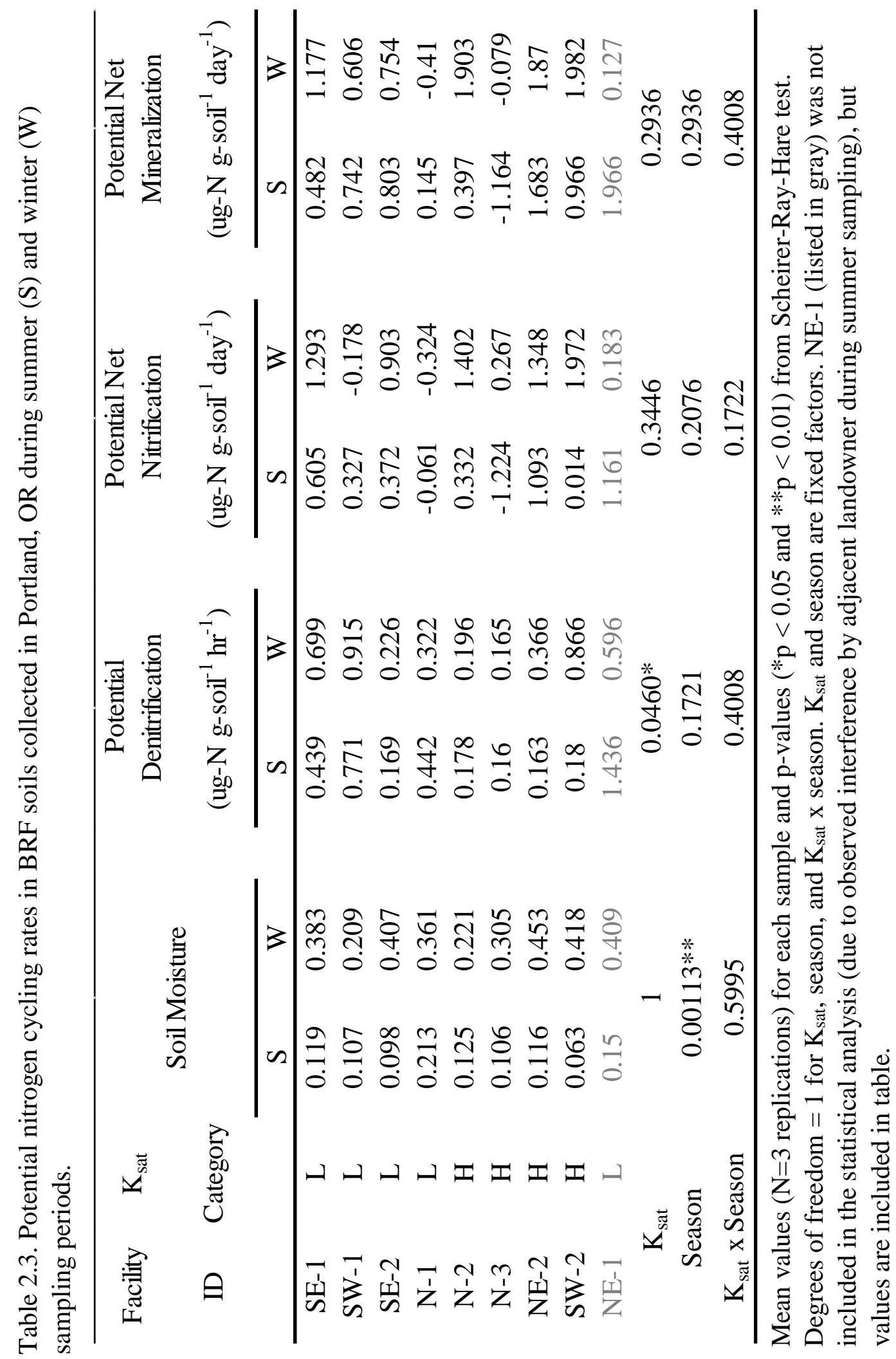



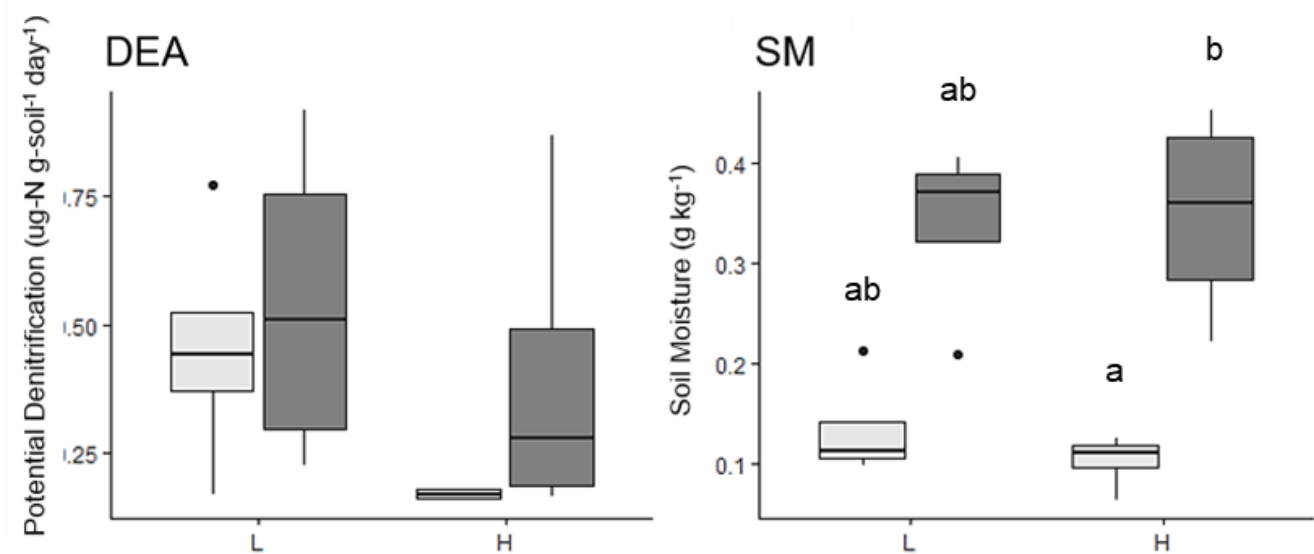

Season
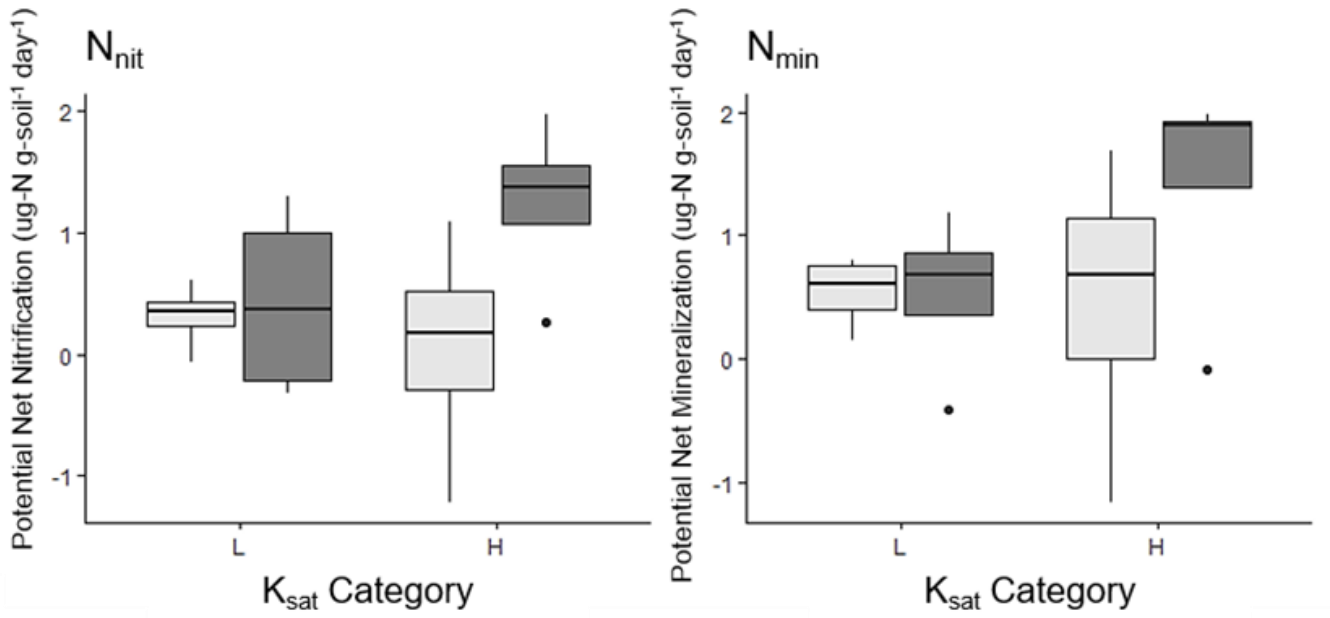

Figure 2.4. $\mathrm{N}$ cycling rates and soil moisture by $\mathrm{K}_{\text {sat }}$ category during each sampling period. Letters indicate differences among categories as determined by Kruskal-Wallis test for mean differences with Dunn test post hoc analyses. If letters are not present, categories were not significantly different.

Potential denitrification was the only variable to show a difference between $\mathrm{K}_{\text {sat }}$ categories, with higher mean rates occurring in soils with low $\mathrm{K}_{\text {sat }}$ values. When with higher mean rates occurring during the winter in fast-infiltrating sites and no mean differences between seasons in the slow-infiltrating sites. There may be a difference in the relationship between moisture inputs and $\mathrm{N}$ cycling with different soil hydrologies: slow-draining sites may have less of a functional response to changes in soil moisture 
than fast-draining sites. Soil moisture, however, is not a direct control on $\mathrm{N}$ cycling processes and serves as a proxy variable for soil oxygen content and an indicator of water residence time, providing an estimation of the degree of anaerobiosis in the soil and the interaction of $\mathrm{N}$ inputs with potential denitrifiers (Firestone et al. 1979; Smith and Tiedje 1979). Additionally, soil moisture is an instantaneous measurement that is representative of the conditions in surface soils at the time of sampling, whereas DEA, $\mathrm{N}_{\text {nit }}$, and $\mathrm{N}_{\min }$ are integrative measurements and are representative of conditions over time (Groffman et al. 2003).

$\mathrm{N}$ cycling parameters may not be tightly coupled to soil moisture in these BRFs due to the variability in other site factors that were not measured, including soil temperature (Groffman et al. 1988). It is expected that under ideal moisture conditions during summer months, the higher temperatures would foster increased microbial activity with corresponding increases in $\mathrm{N}$ cycling rates. This potential interaction between soil moisture and temperature suggests that the mechanism of climate controls on $\mathrm{N}$ cycling is multi-faceted, such that the difference between soil function under warm-dry conditions and cool-wet conditions is not significant here.

Although variables across contrasting $\mathrm{K}_{\text {sat }}$ categories were not significantly different, low $\mathrm{K}_{\mathrm{sat}}(\mathrm{L})$ soils showed smaller ranges in the rates of all $\mathrm{N}$ cycling parameters relative to the larger range in $\mathrm{N}$ cycling rates in high $\mathrm{K}_{\text {sat }}(\mathrm{H})$ soils. The coefficients of variation $(\mathrm{CV})$ were compared across $\mathrm{K}_{\text {sat }}$ for each variable (Figure 2.5). Results showed consistently higher variability in $\mathrm{H}$ soils compared to $\mathrm{L}$ soils, indicating a higher degree of variance from the mean in soils with high $\mathrm{K}_{\text {sat }}$. 


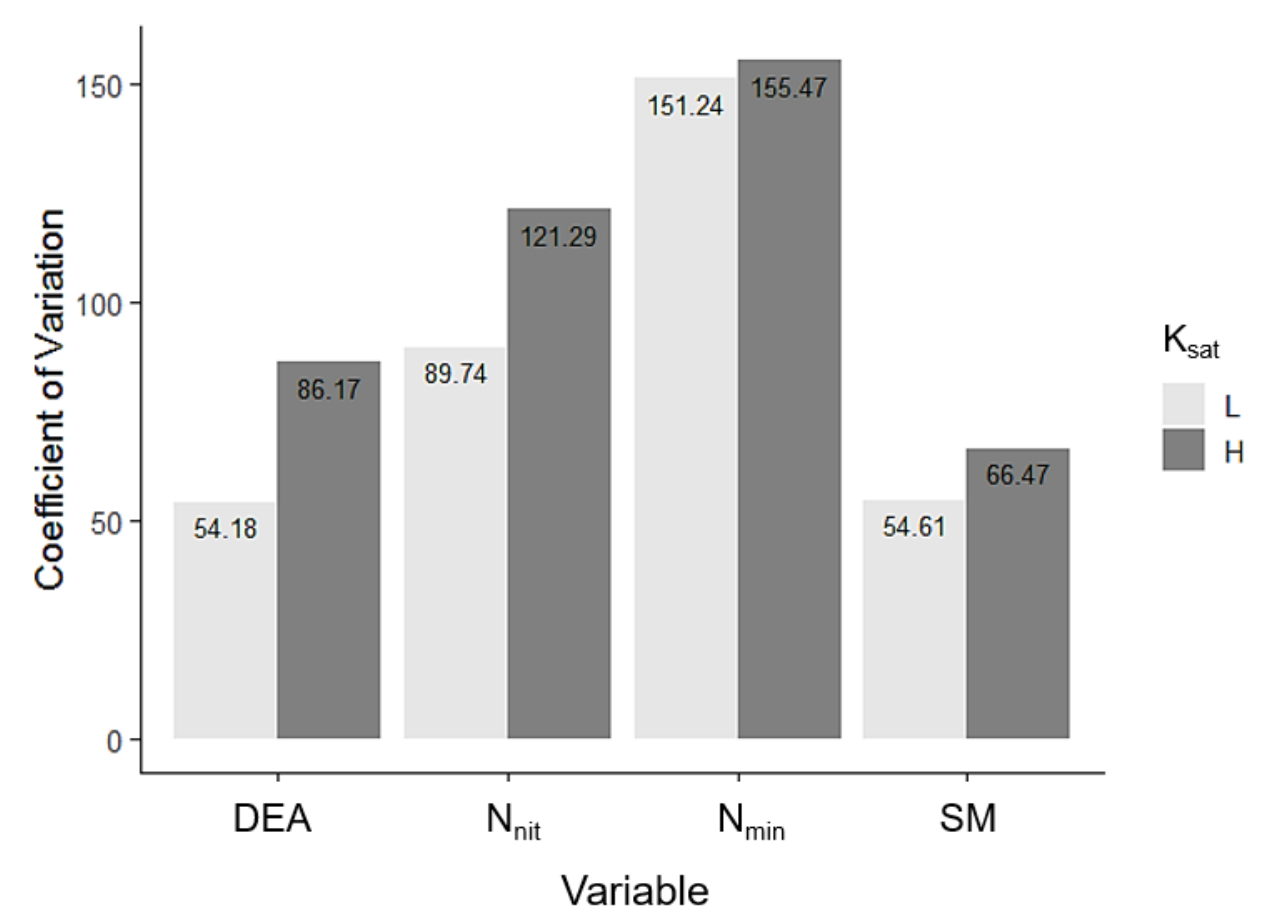

Figure 2.5. Coefficients of variation for each $\mathrm{N}$ cycling variable and for soil moisture in each infiltration category.

These results suggest an influence of soil drainage properties on functional attributes and that function may be less predictable or stable in faster-draining soils and highlights the degree of heterogeneity among BRFs within a single design-type. These results show similar variability in $\mathrm{N}$ cycling processes to preceding studies (Bettez and Groffman 2012; McPhillips and Walter 2015; Morse et al. 2017; Waller et al. 2018), however, these other studies compare $\mathrm{N}$ cycling parameters across various designs of GSI with markedly different hydrologies (e.g. dry detention, infiltration, and permanently 
inundated basins). While these studies suggested that variability in hydrological conditions (wet vs. dry) may play a vital role in $\mathrm{N}$ cycling processes, this present study shows comparable variability in $\mathrm{N}$ cycling variables within a single type of design driven by soil $\mathrm{K}_{\text {sat. }}$.

Large deviations from the means were evident across all $\mathrm{N}$ cycling variables at NE-1 in summer. We excluded these high values as outliers and attribute this result to additional water subsidies that this facility received from an adjacent landowner, based on informal conversations with the landowner during sampling events. Summer microbial activity values at NE-1 are likely artificially elevated relative to natural conditions as a result of this additional input of water, and because they do not reflect the seasonal conditions, values for NE-1 were removed from all statistical analyses.

\section{Potential Nitrogen Removal}

The BRFs in the study included lined and unlined sites. Because unlined sites are intended to infiltrate and filter water to groundwater, estimating the potential nutrient removal capacity relative to inputs is useful in assessing the ability to prevent $\mathrm{N}$ loading to groundwater and receiving waters. To estimate $\mathrm{N}$ removal from stormwater runoff, the potential nitrogen removal within the sampled BRFs was estimated (Eq. 1). The range in total potential $\mathrm{N}$ removal via denitrification in each facility in summer and winter seasons varied by an order of magnitude within seasons but did not show a difference in range between seasons. Facility-scale potential $\mathrm{N}$ removal rates ranged from 0.16 to $8.71 \mathrm{~g}$ $\mathrm{N} /$ day in summer and 0.17 to $5.56 \mathrm{~g}-\mathrm{N} /$ day in winter with no significant differences between seasons (Table 2.4). However, when separated by $\mathrm{K}_{\text {sat }}$, BRFs with $L \mathrm{~K}_{\text {sat }}$ showed 
significantly higher removal rates than $\mathrm{BRF}$ with $\mathrm{H} \mathrm{K}_{\text {sat }}$ across both seasons $(\mathrm{p}=0.013)$.

The estimated rates of $\mathrm{N}$ delivery via runoff to each facility are a function of precipitation and the contributing area of each BRF. Significantly more $\mathrm{N}$ was delivered to sites in winter than summer $(\mathrm{p}=0.004)$ as a result of increased precipitation, ranging from 2.36 to $16.57 \mathrm{~g} / \mathrm{day}$ in winter versus 0.16 to $1.12 \mathrm{~g} / \mathrm{day}$ in summer. Consequently, the removal efficiencies were lower in winter than summer $(\mathrm{p}=0.006$ ), and differences in potential $\mathrm{N}$ removal from summer to winter can be attributed to the seasonality of rainfall and therefore N loading in the Pacific Northwest. Although summer temperatures are warm and facilitate high levels of microbial activity, soils become desiccated during the long intervals between significant precipitation events, limiting microbial $\mathrm{N}$ transformations. When potential removal rates were compared to the estimated incoming $\mathrm{N}$, however, sites demonstrated potentially complete removal efficiencies in summer (2.5 to 26.6 times incoming N). Differences in precipitation between summer and winter drive these results, which do not factor in any seasonal changes in $\mathrm{N}$ concentrations in runoff. Moreover, these results indicate potential removal efficiencies under ideal conditions (anoxic, nutrient-rich soils), likely overestimating actual, in situ rates. All the same, these results suggest that although soils have a significantly higher potential for $\mathrm{N}$ removal during winter conditions, they may not have the capacity to substantially remove the $\mathrm{N}$ loads incoming during periods of heavy rainfall. 
Table 2.4. Potential nitrogen removal rate and efficiency in BRF sites during summer and winter 2015 (using an estimated stormwater runoff $\mathrm{NO}_{3}{ }^{-}$concentration of $2.0 \mathrm{mg} / \mathrm{L}$; Pitt et al. 2004).

\begin{tabular}{|c|c|c|c|c|c|c|}
\hline Season & $\begin{array}{c}\mathrm{K}_{\text {sat }} \\
\text { Category }\end{array}$ & $\begin{array}{c}\text { Facility } \\
\text { ID }\end{array}$ & $\begin{array}{l}\text { Precipitation } \\
(\mathrm{mm} / \mathrm{d})\end{array}$ & $\begin{array}{c}\text { Potential } \\
\text { Removal Rate } \\
\text { (g-N/d) }\end{array}$ & $\begin{array}{l}\text { Incoming } \\
\mathrm{N}(\mathrm{g}-\mathrm{N} / \mathrm{d})\end{array}$ & $\begin{array}{c}\text { Removal } \\
\text { Efficiency } \\
(\%)\end{array}$ \\
\hline \multirow[t]{9}{*}{ Summer } & $\mathrm{H}$ & NE-2 & 0.5 & 0.632 & 0.457 & 138.2 \\
\hline & & SW-2 & & 0.817 & 0.327 & 250.1 \\
\hline & & $\mathrm{N}-3$ & & 0.349 & & \\
\hline & & $\mathrm{N}-2$ & & 0.164 & & \\
\hline & $\mathrm{L}$ & SW-1 & & 1.032 & 0.175 & 589.4 \\
\hline & & $\mathrm{N}-1$ & & 7.070 & 1.120 & 631.1 \\
\hline & & SE-1 & & 4.251 & 0.160 & $2,659.7$ \\
\hline & & NE-1 & & 8.714 & 0.588 & $1,003.6$ \\
\hline & & SE-2 & & 0.692 & & \\
\hline \multirow[t]{9}{*}{ Winter } & $\mathrm{H}$ & NE-2 & 7.4 & 1.113 & 6.767 & 16.4 \\
\hline & & SW-2 & & 4.635 & 4.833 & 95.9 \\
\hline & & $\mathrm{N}-3$ & & 0.305 & & \\
\hline & & $\mathrm{N}-2$ & & 0.169 & & \\
\hline & $\mathrm{L}$ & SW-1 & & 1.124 & 2.590 & 43.4 \\
\hline & & $\mathrm{N}-1$ & & 4.481 & 16.571 & 27.0 \\
\hline & & SE-1 & & 5.562 & 2.364 & 235.2 \\
\hline & & NE-1 & & 3.012 & 8.700 & 34.6 \\
\hline & & SE-2 & & 0.741 & & \\
\hline $\mathrm{K}_{\text {sat }}$ & & & & $0.013 *$ & 1.00 & 0.308 \\
\hline $\begin{array}{c}\text { Season } \\
\mathrm{K}_{\text {sat }} \mathrm{X}\end{array}$ & & & & 0.691 & $0.0040 * *$ & $0.0065 * *$ \\
\hline Season & & & & 0.477 & 1.00 & 0.571 \\
\hline
\end{tabular}

$\overline{\text { Drainage area specifications unavailable for } \mathrm{N}-2, \mathrm{~N}-3 \text {, and SE-2, thus removal efficiency was not estimated }}$ for these sites. P-values ( ${ }^{*} p<0.05$ and $\left.{ }^{* *} p<0.01\right)$ from Scheirer-Ray-Hare test. Degrees of freedom $=1$ for $\mathrm{K}_{\text {sat }}$, season, and $\mathrm{K}_{\text {sat }} \mathrm{X}$ season. $\mathrm{K}_{\text {sat }}$ and season are fixed factors. 
Although results did not indicate significant interaction between season and $\mathrm{K}_{\text {sat }}$ category, the results of this study suggest possible concurrent effects of seasonality and site design. Soils with $\mathrm{L} \mathrm{K}_{\text {sat }}$ showed lower variability in $\mathrm{N}$ cycling variables across seasons relative to $\mathrm{H} \mathrm{K}_{\text {sat }}$, suggesting that soils with lower rates of saturated hydraulic conductivity may support anaerobic microbial functions that are more resilient to changes in seasonal precipitation patterns. Diffusion is the dominant mechanism of oxygen and nutrient transport through soils (Shackelford et al. 1991), and diffusion processes are slower through a saturated soil relative to an unsaturated soil (Runkles 1956). Lower values of $\mathrm{K}_{\text {sat }}$ represent $\mathrm{BRF}$ soils that are likely to drain runoff through the soil slower than higher values of $\mathrm{K}_{\text {sat }}$, limiting oxygen diffusivity to soil microsites. This process may be significant for fostering greater $\mathrm{N}$ removal via denitrification.

Although not included in analyses, results found at the facility coded NE-1 are notable and support the hypothesis that $\mathrm{N}$ cycling rates are driven by soil moisture and temperature. This facility received regular watering from the adjacent land owner with the intention of maintaining moisture to inhibit plant desiccation. Ultimately, this additional input of water functioned as simulated rainfall during the dry summer period. Though soil moisture in this facility at the time of sampling was within the range of all sites, the consistent moisture additions throughout the dry period may have fostered greater microbial growth and activity that is reflected in the elevated $\mathrm{N}$ cycling rates. Conversely, $\mathrm{N}$ cycling parameters at NE-1 are within the range of all sites during the winter sampling period when the facility was no longer receiving additional moisture inputs above the natural conditions. 


\subsection{Conclusions}

The goal of this study was to examine patterns of $\mathrm{N}$ cycling in BRFs across summer and winter conditions to capture seasonal fluctuations in temperature and moisture conditions that are likely to affect soil $\mathrm{N}$ processes. This study did not observe differences in soil $\mathrm{N}$ cycling rates across seasons. Results were contrary to our hypothesis that $\mathrm{N}$ cycling rates, potential denitrification in particular, would show a relationship with soil moisture. However, $\mathrm{N}$ cycling rates were not tightly coupled to the distinct seasonal soil moisture patterns. Results showed an effect of BRF drainage properties on soil $\mathrm{N}$ cycling rates. Higher rates of potential denitrification rates occurred in soils with low saturated hydraulic conductivity, however potential net $\mathrm{N}$ mineralization and potential nitrification rates did not differ between drainage classes. Higher variability in $\mathrm{N}$ cycling rates were observed in soils with high saturated conductivity, suggesting that slower draining soils may foster more stable conditions through time, leading to less variability in soil functions through time. Identifying BRF soil properties that may foster greater moisture retention and stability during dry conditions can lead to design improvements that increase system resilience to drought conditions during intermittent dry periods. BRFs showed the potential for complete $\mathrm{N}$ removal during dry summer conditions when rainfall is low and for incomplete removal efficiencies during wet winter conditions, indicating that BRFs may not substantially remove $\mathrm{N}$ loads during heavy rainfall.

This study suggests that longer residence times may support higher values of $\mathrm{N}$ removal if in situ processes scale similarly to the potential rates measured, as slower rates of infiltration at the soil surface may foster longer residence times and support higher 
proportions of $\mathrm{N}$ removal from runoff. However, this may come with a tradeoff of ecosystem services, as stormwater volume mitigation capacity is reduced with lower rates of infiltration at the soil surface.

This study did not take into account larger-scale variables that may influence relationships between $\mathrm{N}$ cycling parameters, including type and frequency of maintenance activities, plant composition, and undocumented anthropogenic interactions. The possible variability in these diverse influences highlight the non-uniformity of BRFs within the narrow context of BRFs in Portland, OR. Because BRFs are not homogeneous within a single city, heterogeneity across different municipalities may lead to wide variability in function and the potential for $\mathrm{N}$ removal in different settings. The following chapters in this dissertation consider the spatial heterogeneity of BRF soils and how seasonal dynamics affect $\mathrm{N}$ cycling across regions. 


\section{Seasonal and Regional Variability in Nitrogen Cycling Processes in Urban Bioretention Facilities}

\subsection{Introduction}

Increases in impervious surfaces, coupled with subsequent decreases in vegetative cover and the development of piped drainage systems during urban development, alter the natural hydrology of urbanized watersheds, leading to large volumes of runoff that drain to adjacent surface waters (Leopold 1968; Hollis 1977). Consequently, stormwater runoff from urban landscapes is a leading cause of surface water impairment in urban areas (US EPA 2004), and cities face the challenge of developing management solutions to mitigate the damaging environmental and economic effects of urban stormwater.

Green stormwater infrastructure (GSI) is an emerging strategy supported by the US EPA to manage urban stormwater to achieve water quality goals under the Clean Water Act. GSI is implemented to mitigate the deleterious ecological effects of urban stormwater runoff by intercepting runoff using vegetation and soil in engineered structures before it reaches receiving water bodies. Municipalities across the US are increasingly incorporating GSI in stormwater management plans, and GSI is being implemented across contrasting regions (McPhillips and Matsler 2018). For many cities, GSI strategies primarily aim to reduce stormwater runoff volumes, with secondary goals for improved stormwater quality through filtration, assimilation, and transformation of nutrients and contaminants by GSI plants and soils. GSI utilizes a wide range of biological components in the structural design of the systems, and bioretention facilities (BRFs) are one form of 
GSI that is designed to mimic natural hydrological and ecological processes by infiltrating, detaining, storing, evaporating, and filtering local runoff (Dietz et al. 2007).

Due to the application of BRFs in the urban landscape to replace the function of habitats, such as riparian zones, that were lost to urban development, there is a growing interest in assessing important ecosystem processes in BRFs that are characteristic functions of those natural ecosystems, including nitrogen $(\mathrm{N})$ cycling processes. $\mathrm{N}$ is a ubiquitous pollutant that is produced by diverse urban sources, including atmospheric deposition from combustion and vehicle emissions, fertilizer application and runoff, and leaky septic systems (Vitousek et al. 1997; Bettez and Groffman 2013). These sources of $\mathrm{N}$ are mobilized and transported in stormwater runoff, increasing the delivery of biologically available forms of $\mathrm{N}$ to downstream ecosystems (Vitousek 1994; Hamilton et al. 2001). Denitrification processes provide a permanent removal pathway for $\mathrm{N}$ in terrestrial and aquatic ecosystems. Denitrification is the microbially mediated reduction of nitrate $\left(\mathrm{NO}_{3}{ }^{-}\right)$to atmospheric $\mathrm{N}$ gases, thus inhibiting further downstream $\mathrm{N}$ transport. Denitrification occurs at low levels of oxygen, and in soils this occurs when pore spaces become saturated and oxygen diffusion through the soil matrix is reduced (Robertson and Groffman 2015). Other important soil N transformations include N mineralization (the microbial conversion of organic $\mathrm{N}$ to inorganic and bioavailable forms of $\mathrm{N}$ ) and nitrification (the microbial oxidation of ammonium $\left(\mathrm{NH}_{4}^{+}\right)$to $\mathrm{NO}_{3}{ }^{-}$). These processes occur in aerobic conditions, influence the form of bioavailable $\mathrm{N}$ in the soil, and thus are often important precursors to denitrification. Riparian zones are hotspots of $\mathrm{N}$-cycling processes, providing conditions conducive to these processes, denitrification in particular 
(Vidon et al. 2010). Riparian areas are well documented nitrogen sinks, removing dissolved $\mathrm{N}$ through denitrification before it reaches surface waters (Hill 1996; Mayer et al. 2007; Vidon et al. 2010). BRFs are designed to mimic certain functions of riparian zones, and it is hypothesized that BRFs may also act as hotspots for $\mathrm{N}$-cycling processes in the urban landscape (Bettez and Groffman 2012).

Seasonal fluctuations in precipitation and temperature lead to changes in environmental conditions such as soil moisture, bio-available N, and microbial activity rates and subsequent changes in soil $\mathrm{N}$ cycling processes (Pinay et al. 1993; Clément et al. 2002; Harms and Grimm 2008). Some recent studies have measured N-cycling processes in BRFs, but these studies have focused on site-level influences on $\mathrm{N}$-cycling, including the physical, biological, and hydrologic conditions of the site, during a single season or within a single region, (Zhu et al. 2004; Bettez and Groffman 2012; McPhillips and Walter 2015; Morse et al. 2017; Waller et al. 2018) and have not evaluated how Ncycling and its controlling variables change across spatial and temporal contexts in BRFs. To date, no studies have investigated $\mathrm{N}$-cycling patterns in BRFs across seasons and regions.

The objectives of this study were 1) to expand the extent of BRF soil observations and survey soil properties and nitrogen $(\mathrm{N})$ cycling patterns BRFs on the east and west coasts in summer and winter to evaluate the variability in soil bio-physiochemical properties, 2) determine if $\mathrm{N}$-cycling processes show distinct seasonal patterns and whether these patterns change across regions, and 3) identify drivers of the observed patterns across spatial and temporal contexts. We hypothesized that 1) soil properties and 
$\mathrm{N}$-cycling processes would vary between cities due to differences in seasonal precipitation patterns, and 2) the relationships between $\mathrm{N}$-cycling processes and controlling environmental factors would show dynamic interactions across cities and seasons.

To address these objectives, this study compared BRFs in Baltimore, MD and Portland, OR. It was hypothesized that soil moisture and soil organic matter would be primary drivers of $\mathrm{N}$-cycling processes and that these patterns would change across the different seasonal patterns of the two study areas. It was anticipated that Portland BRF soils would show strong seasonal patterns due to the characteristically Mediterranean climate (dry summers and wet winters) and that Baltimore BRF soils would show less seasonal distinction due to more consistent rainfall patterns throughout the year.

\subsection{Methods}

\section{Site Description}

Thirty BRF facilities were selected and sampled in Baltimore $(\mathrm{n}=15)$ and Portland $(\mathrm{n}=15)$ during summer and winter 2016 (Figure 3.1). BRF facilities were selected based on the following criteria: facilities were curbside vegetated stormwater planters or swales located between sidewalks and streets, small-scale $\left(<25 \mathrm{~m}^{2}\right)$, received drainage only from adjacent surfaces (no piped drainage), and dry-type designs that were not permanently inundated between precipitation events. Selected facilities were a mix of unlined, partially-lined, and lined with underdrain, resulting in both infiltrated and treated runoff. 


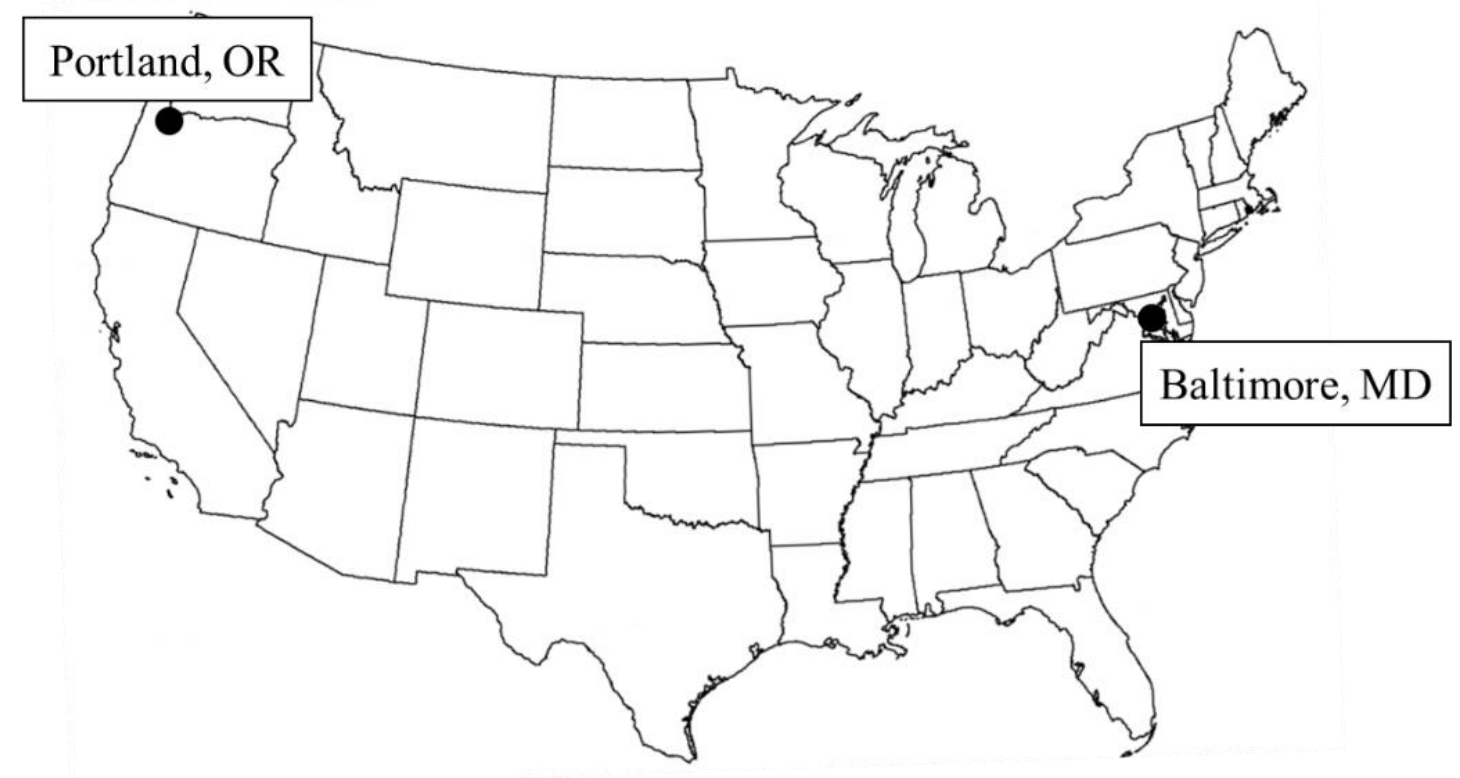

Figure 3.1. Location of study cities: Baltimore, MD and Portland, OR.

Baltimore and Portland were selected as the cities of study due to their use of BRFs as stormwater management strategies and their contrasting seasonal rainfall patterns. Portland has a characteristically Mediterranean climate, with warm, dry summers with little to no rainfall occurring June-August, and mild, wet winters that receive $>80 \%$ of annual rainfall. Baltimore's climate is humid continental, with precipitation falling evenly throughout the year, and approximately $30 \%$ of precipitation occurring in summer, $30 \%$ in winter, and the remaining precipitation occurring in spring and fall (NCDC; Figure 3.2). 
Samples were collected within a two week period in summer (late July-early August) and winter (December) during 2016 to capture seasonal variability. Portland received 2.66 inches and 24.36 inches of rain in summer and winter 2016, respectively, and Baltimore received 13.25 inches and 5.06 inches of rain in summer and winter 2016, respectively (Figure 3.3; NCDC). Baltimore received nearly 5 times as much precipitation in summer prior to sampling, and Portland received nearly 5 times as much precipitation in winter prior to sampling.

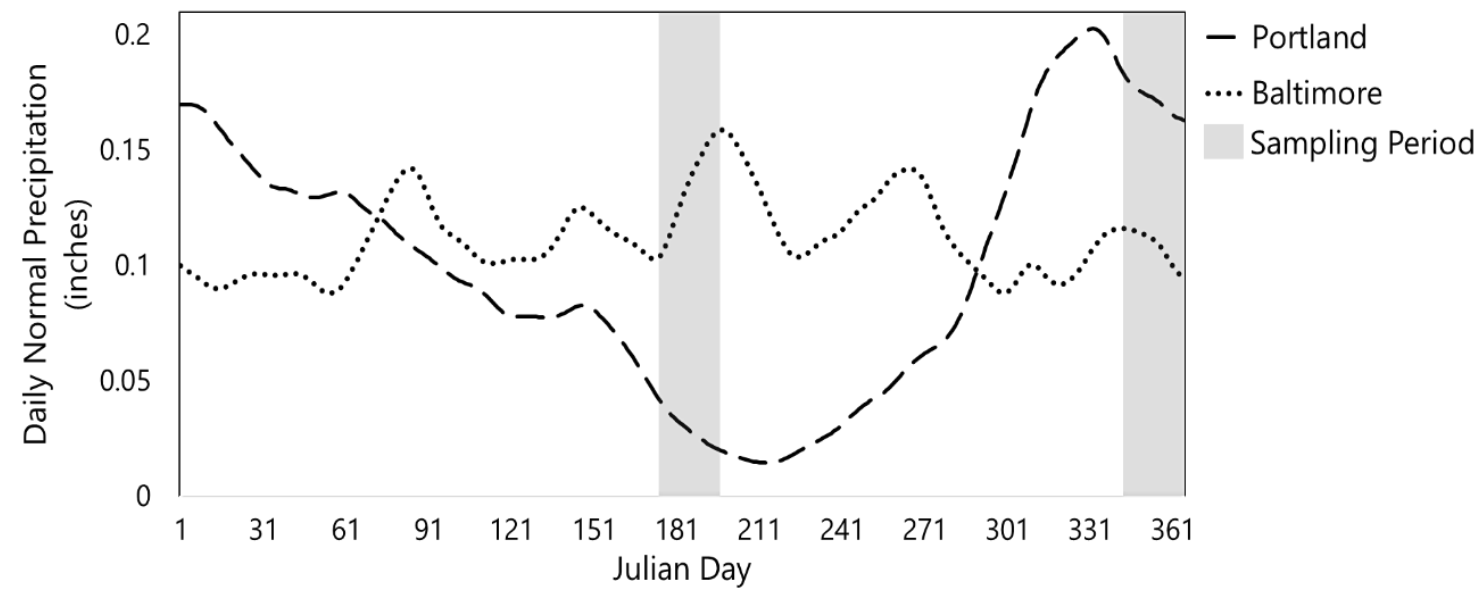

Figure 3.2. 30-year average annual precipitation patterns in Baltimore, MD and Portland, OR. Gray bars indicate the summer and winter sampling periods (NCDC). 


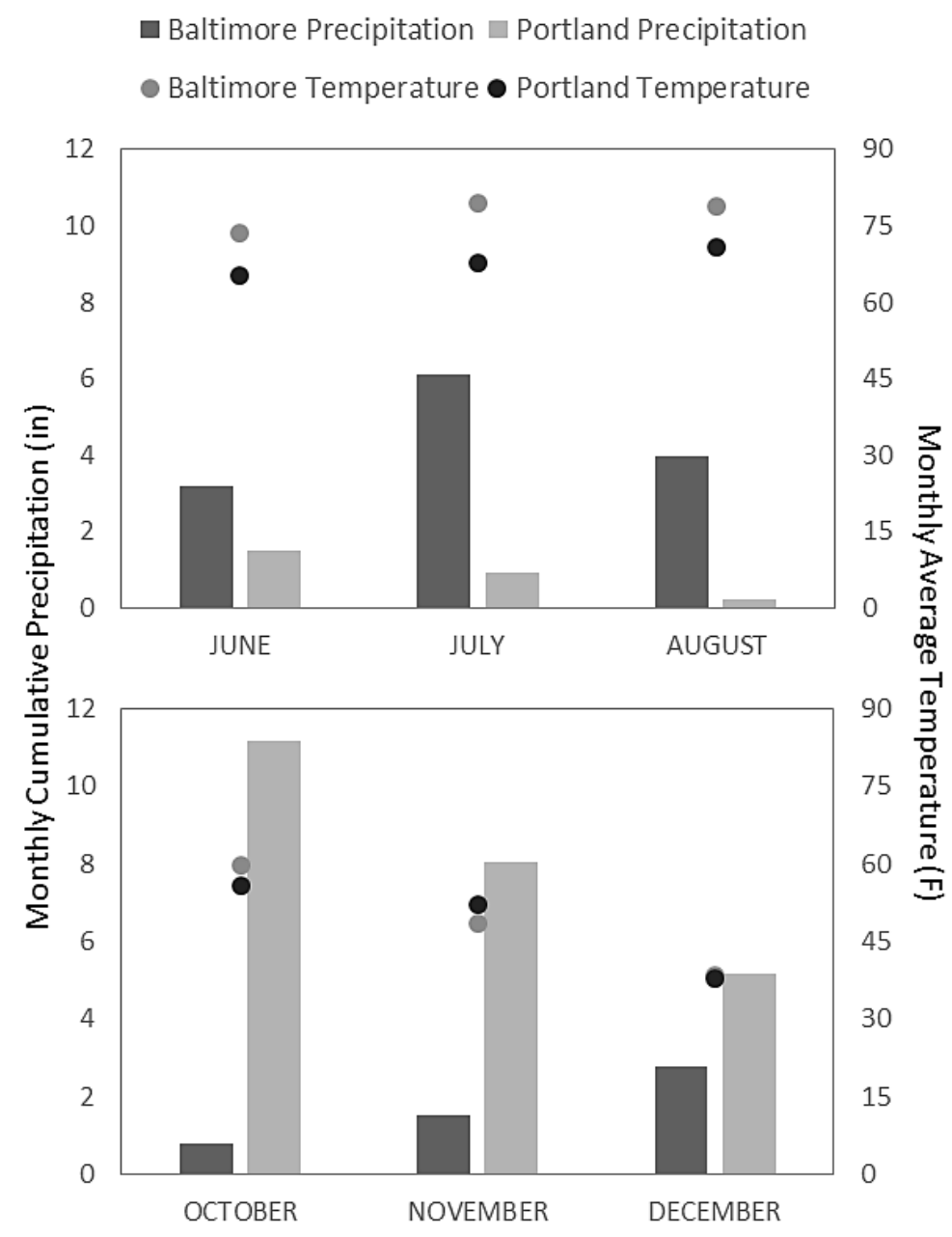

Figure 3.3. Average monthly temperature and antecedent precipitation as monthly cumulative rainfall. Baltimore precipitation is shown by dark bars, and Portland is shown by light bars (NCDC).

\section{Field Methods}

To capture the heterogeneity within each site and any variability in soil conditions from inlet to outlet, 12 soil cores were collected per site and composited into one soil sample. In each site, 3 soil cores were sampled from 4 transects to a depth of 6 inches using a 1 inch diameter AMS nickel-plated steel open-end soil probe and combined into 
one Ziploc bag. The soil samples were kept on ice and immediately brought back to the laboratory where they were stored at $4^{\circ} \mathrm{C}$ until processing within one week of sampling.

\section{Laboratory Methods}

Soils were homogenized and subsampled and analyzed for soil moisture, soil organic matter, microbial biomass $\mathrm{C}$ and $\mathrm{N}$ ( $\mathrm{MBC}$ and $\mathrm{MBN}$, respectively), inorganic $\mathrm{N}$

$\left(\mathrm{NH}_{4}{ }^{+}\right.$and $\left.\mathrm{NO}_{3}{ }^{-}\right)$, potential respiration, potential net nitrification $\left(\mathrm{N}_{\text {nit }}\right)$, potential net mineralization $\left(\mathrm{N}_{\min }\right)$, and potential denitrification.

Denitrification enzyme activity (DEA) was analyzed to determine potential denitrification rates of the soils. We used the chloramphenicol-amended acetylene-block method to measure potential denitrification rates (Tiedje et al. 1989). Triplicate soil slurries were created with $10 \mathrm{~g}$ soil and $10 \mathrm{~mL}$ DI water amended with additional $\mathrm{NO}_{3}{ }^{-}$ (as $\mathrm{KNO}_{3}$ ) and labile carbon (as dextrose) in $125 \mathrm{~mL}$ glass flasks capped with septa. We added chloramphenicol which is an antibiotic that inhibits the production of new enzymes, allowing for denitrification rates measured in bottle assays to be more representative of denitrification activity at the time of sampling (Smith and Tiedje 1979). The flasks were purged with helium to remove oxygen and force anaerobiosis. We injected pure acetylene gas into the sealed, anoxic microcosms through septa caps using a syringe. Acetylene inhibits the conversion of $\mathrm{N}_{2} \mathrm{O}$ to $\mathrm{N}_{2}$ by blocking the activity of $\mathrm{N}_{2} \mathrm{O}$ reductase, such that $\mathrm{N}_{2} \mathrm{O}$ accumulation is an estimate of denitrification rates.

Slurries were incubated at room temperature $\left(22^{\circ} \mathrm{C}\right)$ for 3 hours, and three $5-\mathrm{mL}$ gas samples were removed from the bottle headspaces at 45-minute intervals throughout 
the incubation to measure $\mathrm{N}_{2} \mathrm{O}$ production over time. Flasks were continually mixed on a shaker table set at $125 \mathrm{rpm}$ between measurements to equilibrate $\mathrm{N}_{2} \mathrm{O}$ between the gas and aqueous phases. Gas samples were analyzed immediately by gas chromatography by manually injecting the $5 \mathrm{~mL}$ sample directly into a Shimadzu GC-2014 equipped with a 2 m Porapak Q column and a 63Ni electron capture detector. Concentrations were corrected for $\mathrm{N}_{2} \mathrm{O}$ solubility in the aqueous phase using the temperature-dependent Bunsen coefficient based on ambient laboratory temperature (Knowles 1979). The linear rate of $\mathrm{N}_{2} \mathrm{O}$ production was used to determine the rate of denitrification within each microcosm. Only time periods representing linear production of $\mathrm{N}_{2} \mathrm{O}$ were used for calculations due to potential interference of bottle effects (Groffman and Tiedje 1989). DEA rates were scaled to soil dry-mass $\left(\mathrm{mg}-\mathrm{N}\right.$ g-soil $\left.{ }^{-1} \mathrm{~h}^{-1}\right)$ to determine the flux of $\mathrm{N}$ per unit mass of soil, allowing comparisons across soils of contrasting physical properties.

We determined soil moisture by drying subsamples at $105^{\circ} \mathrm{C}$ for 24 hours, and SOM by loss on ignition at $550^{\circ} \mathrm{C}$ for 4 hours. Microbial biomass $\mathrm{C}$ and $\mathrm{N}$ were measured using the chloroform fumigation incubation method (Jenkinson and Powlson 1976). Samples were fumigated with chloroform to kill and lyse microbial cells (releasing cellular $\mathrm{C}$ and $\mathrm{N}$ ), fumigated soils were inoculated with fresh $0.2 \mathrm{~g}$ soil, and all pairs of fumigated and unfumigated control samples were incubated at $25^{\circ} \mathrm{C}$ for 10 days. During the incubation, microorganisms lysed by chloroform were mineralized to $\mathrm{CO}_{2}$ and $\mathrm{NH}_{4}{ }^{+}$. Prior to and following incubation, extractable $\mathrm{NH}_{4}{ }^{+}$and $\mathrm{NO}_{3}{ }^{-}$were measured in fumigated and control soil by incubating soil with $2.0 \mathrm{M} \mathrm{KCl}$ solution on a shaker table at $125 \mathrm{rpm}$ for one hour to release bound ions into solution. The supernatant was filtered 
through $2.5 \mu \mathrm{m}$ Whatman filters using gravimetric filtration. Concentrations of inorganic $\mathrm{N}\left(\mathrm{NH}_{4}{ }^{+}\right.$and $\left.\mathrm{NO}_{3}{ }^{-}\right)$were measured colorimetrically in filtered samples using the salicylate method for $\mathrm{NH}_{4}{ }^{+}$and the cadmium reduction method for $\mathrm{NO}_{3}{ }^{-}$using a SmartChem 170 discrete analyzer (Unity Scientific, Milford, MA). The amount of $\mathrm{CO}_{2}$ and $2 \mathrm{M} \mathrm{KCl}$-extractable inorganic $\mathrm{N}$ produced in the fumigated soils during the incubation is proportional to the amount of $\mathrm{C}$ and $\mathrm{N}$ in the microbial biomass in the soil. $\mathrm{CO}_{2}$ produced in the unfumigated control samples was used to estimate microbial respiration. Inorganic $\mathrm{N}$ in pre- and post-incubation control soils were used to calculate potential net $\mathrm{N}$ mineralization (production of inorganic $\mathrm{N}$ ) and potential net nitrification (transformation of $\mathrm{NH}_{4}{ }^{+}$to $\mathrm{NO}_{3}{ }^{-}$via net change in $\mathrm{NO}_{3}{ }^{-}$). Soil $\mathrm{pH}$ was determined by equilibrating $15 \mathrm{~g}$ of soil with $30 \mathrm{~mL}$ DI water at room temperature for 30 minutes. Following equilibration, $\mathrm{pH}$ readings were taken from duplicate soil samples from each site using a Thermo Scientific Orion Star A111 pH benchtop meter (Thermo Fisher Scientific, Waltham, MA).

Soil texture was analyzed using laser diffraction analysis. Soils were prepared by passing air-dried soil was through a $2.0 \mathrm{~mm}$ sieve. Particles $<2.0 \mathrm{~mm}$ were incubated with $100 \mathrm{~mL}$ of a $5 \%$ sodium hexametaphosphate (HMP) solution on a shaker table for 16 hours to deflocculate particles. Following deflocculation, soils were air-dried and subsampled ( $1 \mathrm{~g}$ ) for organic content removal via digestion with a $3 \%$ hydrogen peroxide solution $\left(\mathrm{H}_{2} \mathrm{O}_{2}\right) . \mathrm{H}_{2} \mathrm{O}_{2}$ was added to the subsampled soils in increments of $2.5 \mathrm{~mL}$ to reach a total of $12.5 \mathrm{~mL}$. Digestions were incubated in a hot bath until completion. Samples were rehydrated with HMP solution, and sonicated for 5 seconds prior to 
analysis. Slurries were injected into a Becker Coulter LS 13320 Particle Sizing Analyzer to analyze particle distributions for particles between $0.001 \mathrm{~mm}-2.0 \mathrm{~mm}$. The resulting proportion of silts and clays were combined to produce the percent of fines (\% fines) present in each BRF soil, which is the value used to represent soil texture in statistical analyses. Soil texture was assumed to be static across the two sampling intervals and was only measured on soil samples collected in winter 2016.

\section{Statistical Methods}

The objective of this study was to determine the variability in soil properties and $\mathrm{N}$-cycling processes across regions with variable weather patterns and evaluate how patterns change across seasons. Shapiro-Wilk tests were used to test assumptions of normal distribution. No parameters followed normal distributions, and lognormal or $\mathrm{x}^{1 / 4}$ transformations were used to meet assumptions of normality across variables. To determine if there were significant differences or interactions between city and season on soil properties and $\mathrm{N}$-cycling processes, two-way analysis of variance (ANOVA) with interactions was performed on transformed variables with city and season as independent factors and soil properties and $\mathrm{N}$-cycling variables as dependent factors. Tukey honestly significant difference (HSD) pairwise comparisons were performed on ANOVA results to compare among cities and seasons. Significant differences were considered at or below pvalues of 0.05 .

Multiple linear regression models were developed for each $\mathrm{N}$-cycling process for both cities during each sampling interval to compare the relationships between controlling environmental factors and microbially-mediated $\mathrm{N}$ transformations. 
Untransformed data were used in the multiple linear regression models as residuals produced in the model followed assumptions of normality. Candidate predictor variables were chosen based on Spearman rank correlation coefficients that indicated a relationship between predictor and response variables. Variable selection was used to select the best subset of predictor variables to describe each $\mathrm{N}$-cycling variable using the step function in R. Stepwise multiple linear regression (forward and backward) with automated variable selection based on Akaike's information criterion (AIC) was used to identify the combination of variables that best described $\mathrm{N}$-cycling variables. All statistical analyses were performed in $\mathrm{R}$ version 3.5.2 ( $\mathrm{R}$ Development Core Team 2008).

\subsection{Results and discussion}

\section{Soil properties}

Soil bio-physicochemical properties showed variability across and within cities and seasons. (Table 3.1). $\mathrm{MBN}$, and $\mathrm{NO}_{3}{ }^{-}$were significantly higher in winter than summer in both Portland and Baltimore. MBC showed the opposite seasonal trend with higher values in summer than winter in both cities, although this difference was only significant in Baltimore. Soil moisture (gravimetric water content) showed no difference between seasons. These patterns in soil moisture correspond to antecedent precipitation patterns during sampling periods. Baltimore received similar depths of rainfall during the week prior to sampling during summer (2.5 inches) and winter (1.20 inches). In contrast, Portland received no rainfall in the week leading up to sampling in summer and 3.25 inches in the week prior to sampling in winter. 
When pooled across seasons, all soil properties except MBN and soil moisture showed significant differences $(\mathrm{p}<0.05)$ across cities, with significantly higher MBC, $\mathrm{SOM}, \mathrm{NO}_{3}{ }^{-}, \mathrm{NH}_{4}{ }^{+}$, and \% fines and significantly lower $\mathrm{pH}$ occurring in Portland (Table 3.2). $\mathrm{MBC}, \mathrm{MBN}$, soil moisture, and $\mathrm{NH}_{4}{ }^{+}$showed significant interactions between city and season. These results suggest that certain soil properties may be relatively static without significant variability across seasons, including SOM and $\mathrm{pH}$. It can be assumed that soil texture falls within this suite of static soil properties in the short term barring the occurrence of any major disturbance or soil transport process. Other soil biophysiochemical properties including $\mathrm{MBC}, \mathrm{MBN}$, soil moisture, and $\mathrm{NO}_{3}{ }^{-}$showed dynamic seasonal patterns and are likely impacted by seasonal precipitation and temperature patterns. 
Table 3.1. Average soil properties (SD) in BRFs in Baltimore, MD and Portland, OR in summer and winter 2016. Superscripts indicate results from one-way ANOVA with Tukey HSD post hoc analyses. For each parameter, values with different letters are significantly different from each other $(\mathrm{p}<0.05)$.

\begin{tabular}{|c|c|c|c|c|c|c|c|c|}
\hline $\begin{array}{l}\text { City and } \\
\text { Season }\end{array}$ & $\begin{array}{l}\text { MBC } \\
\text { (mg-C } \\
\text { /g-soil) }\end{array}$ & $\begin{array}{c}\text { MBN } \\
\text { (ug-N } \\
\text { /g-soil) }\end{array}$ & $\begin{array}{c}\% \text { SM } \\
\text { (\% dry } \\
\text { weight })\end{array}$ & $\begin{array}{c}\% \text { SOM } \\
\text { (\% dry } \\
\text { weight) }\end{array}$ & $\underset{\left(-\log \left[\mathrm{H}^{+}\right]\right)}{\mathrm{pH}}$ & $\begin{array}{c}\mathrm{NO}_{3}-\mathrm{N} \\
\text { (ug-N/ } \\
\text { g-soil) }\end{array}$ & $\begin{array}{c}\mathrm{NH}_{4}-\mathrm{N} \\
\text { (ug-N/ } \\
\text { g-soil) }\end{array}$ & $\begin{array}{c}\% \\
\text { Fines }\end{array}$ \\
\hline $\begin{array}{l}\text { Baltimore } \\
\text { Summer }\end{array}$ & $\begin{array}{c}1.68 \\
(0.46)^{b}\end{array}$ & $\begin{array}{l}23.10 \\
(7.62)^{\mathrm{c}}\end{array}$ & $\begin{array}{c}25.25 \\
(10.25)^{\mathrm{b}}\end{array}$ & $\begin{array}{c}5.54 \\
(1.67)^{\mathrm{b}}\end{array}$ & $\begin{array}{c}7.66 \\
(0.44)^{\mathrm{b}}\end{array}$ & $\begin{array}{c}2.17 \\
(3.67)^{\mathrm{c}}\end{array}$ & $\begin{array}{c}4.14 \\
(3.39)^{\mathrm{a}}\end{array}$ & $\begin{array}{c}24.37 \\
(5.78)^{b}\end{array}$ \\
\hline $\begin{array}{c}\text { Baltimore } \\
\text { Winter }\end{array}$ & $\begin{array}{c}0.98 \\
(0.41)^{\mathrm{c}}\end{array}$ & $\begin{array}{c}38.89 \\
(11.24)^{\mathrm{b}}\end{array}$ & $\begin{array}{c}25.25 \\
(8.28)^{b}\end{array}$ & $\begin{array}{c}5.57 \\
(1.76)^{\mathrm{b}}\end{array}$ & $\begin{array}{c}7.58 \\
(0.21)^{b}\end{array}$ & $\begin{array}{c}7.57 \\
(4.330)^{\mathrm{b}}\end{array}$ & $\begin{array}{c}0.37 \\
(0.45)^{\mathrm{b}}\end{array}$ & \\
\hline $\begin{array}{l}\text { Portland } \\
\text { Summer }\end{array}$ & $\begin{array}{c}2.01 \\
(1.91)^{\mathrm{ab}}\end{array}$ & $\begin{array}{c}13.31 \\
(9.81)^{\mathrm{d}}\end{array}$ & $\begin{array}{c}21.67 \\
(12.93)^{\mathrm{b}}\end{array}$ & $\begin{array}{c}10.70 \\
(3.68)^{\mathrm{a}}\end{array}$ & $\begin{array}{c}5.96 \\
(0.61)^{\mathrm{a}}\end{array}$ & $\begin{array}{c}10.50 \\
(8.08)^{\mathrm{b}}\end{array}$ & $\begin{array}{c}3.60 \\
(4.52)^{\mathrm{a}}\end{array}$ & $\begin{array}{c}47.21 \\
(17.64)^{\mathrm{a}}\end{array}$ \\
\hline $\begin{array}{l}\text { Portland } \\
\text { Winter }\end{array}$ & $\begin{array}{c}1.89 \\
(0.50)^{\mathrm{b}}\end{array}$ & $\begin{array}{c}101.81 \\
(47.50)^{\mathrm{a}}\end{array}$ & $\begin{array}{c}38.95 \\
(6.57)^{\mathrm{a}}\end{array}$ & $\begin{array}{c}10.14 \\
(2.88)^{\mathrm{a}}\end{array}$ & $\begin{array}{c}6.29 \\
(0.44)^{\mathrm{a}}\end{array}$ & $\begin{array}{c}31.93 \\
(31.61)^{\mathrm{a}}\end{array}$ & $\begin{array}{c}5.48 \\
(3.57)^{\mathrm{a}}\end{array}$ & \\
\hline
\end{tabular}

Table 3.2. Two-way ANOVA results assessing the effects of and interaction between city (Baltimore, MD and Portland, OR) and season (summer and winter 2016) on soil properties.

\begin{tabular}{|c|c|c|c|c|c|c|c|c|}
\hline & $\begin{array}{c}\mathrm{MBC} \\
\text { (mg-C/g- } \\
\text { soil) }\end{array}$ & $\begin{array}{c}\mathrm{MBN} \\
\text { (ug-N/g- } \\
\text { soil) }\end{array}$ & $\begin{array}{l}\% \text { SM } \\
\text { (\% dry } \\
\text { weight) }\end{array}$ & $\begin{array}{c}\% \text { SOM } \\
\text { (\% dry } \\
\text { weight) }\end{array}$ & $\begin{array}{c}\mathrm{pH} \\
(- \\
\log [\mathrm{H}+])\end{array}$ & $\begin{array}{c}\mathrm{NO}_{3}-\mathrm{N} \\
\text { (ug-N/g- } \\
\text { soil) }\end{array}$ & $\begin{array}{c}\mathrm{NH}_{4}-\mathrm{N} \\
\text { (ug-N/g- } \\
\text { soil) }\end{array}$ & $\%$ Fines \\
\hline City & 0.005 & 0.109 & 0.115 & $<0.0001$ & $<0.0001$ & $<0.0001$ & 0.0006 & $<0.0001$ \\
\hline City:Season & 0.002 & $<0.0001$ & 0.0008 & 0.77 & 0.085 & 0.93 & $<0.0001$ & - \\
\hline
\end{tabular}




\section{Potential denitrification}

DEA rates ranged from 0.05-1.28 ug-N/g-soil/hr in Baltimore and 0.11-1.59 ugN/g-soil/hr in Portland (Figure 3.4; Table 3.3). When pooled across seasons, Portland had significantly higher DEA rates than Baltimore $(\mathrm{p}<0.001)$. There was not a significant interaction between city and season for DEA rates (Table 3.4).
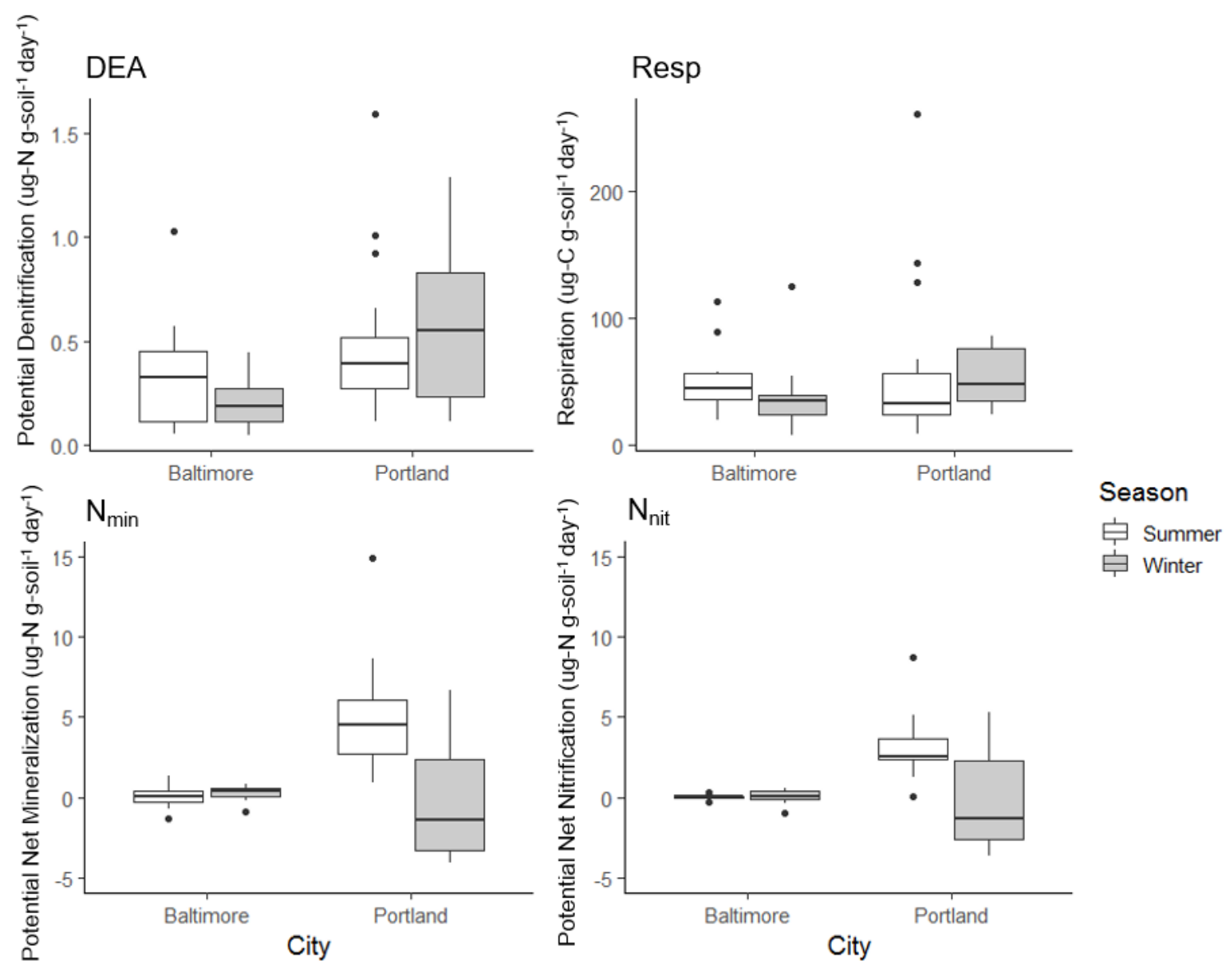

Figure 3.4. Average A) potential denitrification, B) respiration, C) potential net $\mathrm{N}$ mineralization, and D) potential net nitrification in Baltimore, MD and Portland, OR 
during summer and winter 2016. Categories were not significantly different for any variables.

Table 3.3. Average N-cycling parameters (SD) in BRFs in Baltimore, MD and Portland, OR in summer and winter 2016. Superscripts indicate results from one-way ANOVA with Tukey HSD post hoc analyses. For each parameter, values with different letters are significantly different from each other $(\mathrm{p}<0.05)$.

\begin{tabular}{cccccc}
\hline City & Season & $\begin{array}{c}\text { DEA } \\
\text { (ug-N/g-soil/hr) }\end{array}$ & $\begin{array}{c}\text { Potential Net N } \\
\text { Mineralization } \\
\text { (ug-N/g-soil/day) }\end{array}$ & $\begin{array}{c}\text { Potential Net } \\
\text { Nitrification } \\
\text { (ug-N/g-soil/day) }\end{array}$ & $\begin{array}{c}\text { Respiration } \\
\text { (ug-C/g-soil/day) }\end{array}$ \\
\hline Baltimore & Summer & $0.36(0.31)^{\mathrm{bc}}$ & $0.005(0.64)^{\mathrm{c}}$ & $-0.004(0.16)^{\mathrm{b}}$ & $48.95(24.16)^{\mathrm{a}}$ \\
& Winter & $0.26(0.25)^{\mathrm{c}}$ & $0.26(0.45)^{\mathrm{c}}$ & $0.024(0.40)^{\mathrm{b}}$ & $38.05(26.91)^{\mathrm{a}}$ \\
\multirow{2}{*}{ Portland } & Summer & $0.50(0.40)^{\mathrm{ab}}$ & $5.06(3.47)^{\mathrm{ab}}$ & $2.95(2.11)^{\mathrm{a}}$ & $61.16(67.42)^{\mathrm{a}}$ \\
& Winter & $0.59(0.39)^{\mathrm{ab}}$ & $-0.32(3.37)^{\mathrm{b}}$ & $-0.30(2.85)^{\mathrm{a}}$ & $52.51(22.15)^{\mathrm{a}}$ \\
\hline
\end{tabular}

Table 3.4. Two-way ANOVA results assessing the effects of and interaction between city (Baltimore, MD and Portland, OR) and season (summer and winter 2016) on N-cycling parameters.

\begin{tabular}{ccccc}
\hline ANOVA Factor & DEA & $\begin{array}{c}\text { Potential Net } \\
\text { Mineralization }\end{array}$ & $\begin{array}{c}\text { Potential Net } \\
\text { Nitrification }\end{array}$ & Respiration \\
\hline City & 0.0009 & $<0.0001$ & $<0.0001$ & 0.490 \\
City:Season & 0.164 & 0.158 & 0.332 & 0.042 \\
\hline
\end{tabular}

Spearman correlation coefficients were used as indicators of univariate relationships between DEA and soil moisture, $\mathrm{SOM}, \mathrm{MBC}, \mathrm{MBN}, \mathrm{NO}_{3}{ }^{-}, \mathrm{pH}$, and \% fines. Bi-directional stepwise multiple regression with variable selection by AIC determined best-fit models for DEA in each season in each city. Final multiple regression models were all significant $(\mathrm{p}<0.05)$ with explanatory power greater than $50 \%$ for each city- 
season and revealed different multivariate controls on DEA across cities and seasons

(Table 3.5).

Table 3.5. Multiple linear regression model results comparison. Asterisks highlighted by the gray bars indicate the initial variables tested for each $\mathrm{N}$ cycling process. Final models were generated using AIC forward and backward steps to select input variables. Positive and negative signs indicate the variables selected for each model and the sign of the model coefficient for each variable. Adjusted $\mathrm{R}^{2}$ and $\mathrm{p}$-values for each model are shown to the right. Full models shown in Table B.1 in Appendix B.

\begin{tabular}{|c|c|c|c|c|c|c|c|c|c|c|c|c|c|c|}
\hline \multirow[b]{2}{*}{ Process } & \multirow[b]{2}{*}{ City } & \multirow[b]{2}{*}{ Season } & \multicolumn{10}{|c|}{ Variables Tested } & \multirow[b]{2}{*}{$R^{2}$} & \multirow[b]{2}{*}{$p$} \\
\hline & & & $\begin{array}{c}\text { Soil } \\
\text { Moisture }\end{array}$ & SOM & $\mathrm{NO}_{3}-\mathrm{N}$ & $\mathrm{NH}_{4}-\mathrm{N}$ & MBC & MBN & $\mathrm{pH}$ & $\%$ fines & $\mathrm{N}_{\min }$ & $\begin{array}{c}\text { Microbial } \\
\text { C:N }\end{array}$ & & \\
\hline \multicolumn{3}{|l|}{ DEA } & * & $*$ & $*$ & & $*$ & $*$ & $*$ & $*$ & & & & \\
\hline & \multirow[t]{2}{*}{ Baltimore } & \multirow{2}{*}{$\begin{array}{l}\text { Summer } \\
\text { Winter }\end{array}$} & + & + & + & & & & & & & & 0.74 & 0.0005 \\
\hline & & & + & & & & & & & & & & 0.56 & 0.0008 \\
\hline & \multirow[t]{2}{*}{ Portland } & \multirow{2}{*}{$\begin{array}{c}\text { Summer } \\
\text { Winter }\end{array}$} & & & - & & - & + & + & & & & 0.76 & 0.0007 \\
\hline & & & - & + & & & + & & & & & & 0.63 & 0.0027 \\
\hline \multirow[t]{5}{*}{$\mathrm{N}_{\min }$} & & & $*$ & $*$ & & $*$ & & & & $*$ & & $*$ & & \\
\hline & \multirow[t]{2}{*}{ Baltimore } & Summer & - & & & & & & & & & & 0.1 & 0.13 \\
\hline & & Winter & & - & & & & & & & & & 0.14 & 0.09 \\
\hline & \multirow[t]{2}{*}{ Portland } & Summer & + & & & & & & & & & - & 0.69 & 0.0004 \\
\hline & & Winter & & - & & & & & & & & & 0.35 & 0.012 \\
\hline \multicolumn{3}{|l|}{$\mathrm{N}_{\text {nit }}$} & $*$ & $*$ & & $*$ & & $*$ & & $*$ & $*$ & & & \\
\hline & \multirow[t]{2}{*}{ Baltimore } & Summer & & & & & & & & + & & & 0.28 & 0.06 \\
\hline & & Winter & - & - & + & & & & & + & & & 0.9 & $<0.0001$ \\
\hline & \multirow[t]{2}{*}{ Portland } & Summer & - & + & + & & & + & & & + & & 0.76 & 0.002 \\
\hline & & Winter & & & - & & & & & & & & 0.99 & $<0.0001$ \\
\hline \multirow[t]{5}{*}{ Resp } & & & $*$ & $*$ & & & $*$ & & & $*$ & & & & \\
\hline & \multirow[t]{2}{*}{ Baltimore } & Summer & + & + & & & & & & + & & & 0.9 & $<0.0001$ \\
\hline & & Winter & + & & & & + & & & & & & 0.83 & $<0.0001$ \\
\hline & \multirow[t]{2}{*}{ Portland } & Summer & + & + & & & + & & & - & & & 0.95 & $<0.0001$ \\
\hline & & Winter & + & & & & + & & & - & & & 0.73 & 0.0005 \\
\hline
\end{tabular}

It was expected that soil moisture would be a primary driving variable on DEA, particularly during summer conditions in Portland. Contrary to this hypothesis and the 
fact that lower DEA rates and soil moisture were found in Portland during summer, soil moisture did not improve the fit of the model for Portland-summer and was rejected from the final model. Soil texture did not appear to have a significant impact on DEA and was not chosen for any model. MBN and $\mathrm{pH}$ were only selected in the Portland-summer model. Soil moisture, $\mathrm{SOM}$, and $\mathrm{NO}_{3}{ }^{-}$explained $73.6 \%$ of the variability in DEA in Baltimore-summer $(\mathrm{p}=0.00045)$. Soil moisture was the final model for Baltimore-winter and explained $56.4 \%$ of the variability in DEA ( $\mathrm{p}=0.00076)$. Portland-summer produced the most complex model with $\mathrm{MBN}, \mathrm{MBC}, \mathrm{pH}$, and $\mathrm{NO}_{3}{ }^{-}$explaining $76.2 \%$ of variability in DEA ( $\mathrm{p}=0.00074)$. MBC, soil moisture, and SOM explained $63.2 \%$ of variability in DEA in Portland-winter ( $\mathrm{p}=0.0027)$. The models had less explanatory power during winter in each city. Clear patterns emerged from multivariate regression models across cities or seasons, suggesting that the relationship of DEA to regulating factors is different across regional contexts and dynamic across seasonal conditions. This may be due to changing availability of resources or fluctuations in stressors that inhibit denitrification processes that were not captured in this study. Despite the variability in the explanatory relationships between soil properties and DEA across seasons, seasonal DEA rates did not differ significantly within either city.

Compared to other published values of DEA in the literature, DEA rates were within the range of measurements in GSI in Baltimore during a late summer investigation (1-1.49 mg-N/kg/h), however, these measurements were made in larger scale wet- and dry- detention basins rather than small-scale, curbside BRF (Bettez and Groffman 2012). To date, no previous studies have evaluated DEA in BRFs in Portland or the Northwest 
US. Together, the similarity in range and wide variability of rates of DEA between these distinct regions suggest that denitrification in urban stormwater basins is likely stimulated by a combination of inputs of heterogeneous organic matter and nutrients from urban runoff with additions of these materials from management activities (Zhu et al. 2004).

\section{Mineralization}

Potential net $\mathrm{N}$ mineralization rates ranged from -1.38 to $1.36 \mathrm{ug}-\mathrm{N} / \mathrm{g}$-soil/day in Baltimore and -4.09 to $14.91 \mathrm{ug}-\mathrm{N} / \mathrm{g}$-soil/day in Portland with the highest average rates occurring in the summer in Portland and in the winter in Baltimore, however $\mathrm{N}_{\min }$ rates were not significantly different across seasons in either city (Table 3.4). When pooled across seasons, Portland had significantly higher $\mathrm{N}_{\min }$ rates than Baltimore $(\mathrm{p}<0.0001)$. There was not a significant interaction between city and season on $\mathrm{N}_{\min }$ rates.

Negative $\mathrm{N}_{\min }$ rates represent a greater degree of immobilization (conversion of $\mathrm{N}$ into organic forms) than mineralization (conversion of $\mathrm{N}$ into inorganic forms) and were observed in sites across both cities. Rates of mineralization activity are regulated by temperature and soil moisture, increasing with temperature and highest at intermediate soil water contents, but the quantity and quality (availability of $\mathrm{C}$ relative to availability of $\mathrm{N}$ in the material) of organic matter are the primary factors that drive the balance of mineralization and immobilization. (Robertson and Groffman 2015). Mineralization rates were observed to increase with increasing ratios of microbial biomass $\mathrm{C}: \mathrm{N}$ across all sites, and immobilization was observed at the lowest microbial C:N ratios. Immobilization is expected to occur at higher soil C:N ratios, and the microbial C:N fraction may reflect the microbial response to $\mathrm{C}: \mathrm{N}$ ratios in the bulk soil. At higher soil 
C: $\mathrm{N}$ ratios when $\mathrm{N}$ is less available, microorganisms will immobilize and internalize $\mathrm{N}$, and this will likely be reflected in low microbial biomass $\mathrm{C}: \mathrm{N}$ ratios. $\mathrm{N}$ immobilization occurred primarily in summer in Baltimore and in winter in Portland. This seasonal difference in $\mathrm{N}$ immobilization patterns suggests a possible coupled influence of SM and temperature on the balance between mineralization and immobilization patterns.

Spearman correlation coefficients were used to indicate univariate relationships between $\mathrm{N}_{\min }$ and SM, SOM, microbial C:N, and \% fines. Variables for final multiple regression models were auto-selected through bi-directional stepwise multiple regression with variable selection by AIC to determine best-fit models explaining $\mathrm{N}_{\min }$ in each season in each city. The explanatory power of the selected models for $\mathrm{N}_{\min }$ in Baltimore was low, and final regression models were only significant for Portland-summer and Portland-winter (Table 3.5). It was expected that SM and microbial C:N ratios would be important controls on $\mathrm{N}_{\min }$ patterns across cities. $\mathrm{SM}$ appeared as the primary influence on $\mathrm{N}_{\min }$ during summer in both cities, but microbial C:N ratios were only selected for the Portland-summer model. SOM appeared as the primary influence on $\mathrm{N}_{\min }$ during winter in both cities.

Relative to previous measurements in Baltimore GSI with averages ranging from 0.05-0.41 ug-N/g-soil/day in dry-type facilities, $\mathrm{N}_{\min }$ rates observed in Baltimore BRFs in this study were low. $\mathrm{N}_{\min }$ rates in Portland BRFs were high relative to this range. These patterns suggest that the high SOM content of Portland BRFs may have higher quality organic sources, decreasing the soil C:N ratios that facilitate high conversion rates of $\mathrm{N}$ into inorganic forms. 


\section{Nitrification}

$\mathrm{N}_{\text {nit }}$ rates ranged from -0.96-0.57 ug-N/g-soil/hr in Baltimore and -3.69-8.76 ug$\mathrm{N} / \mathrm{g}$-soil/hr in Portland (Table 3.3). Similar to $\mathrm{N}_{\min }$ patterns, $\mathrm{N}_{\text {nit }}$ rates were lowest in summer and highest in winter in Baltimore, and rates were lowest in winter and highest in summer in Portland though not significantly different between seasons in either city. When pooled across seasons, Portland had significantly higher $\mathrm{N}_{\text {nit }}$ rates than Baltimore $(\mathrm{p}<0.001)$. There was not a significant interaction between city and season on $\mathrm{N}_{\text {nit }}$ rates.

Spearman correlation coefficients indicated univariate relationships between $\mathrm{N}_{\text {nit }}$ and $\mathrm{NH}_{4}{ }^{+}, \mathrm{N}_{\min }, \mathrm{SM}, \mathrm{SOM}, \mathrm{MBN}$, and \% fines. Best-fit models for $\mathrm{N}_{\text {nit }}$ for each season in each city were determined using auto-selection with bi-directional stepwise multiple regression using AIC variable selection. $\mathrm{NH}_{4}{ }^{+}$was expected to be an important variable across contexts because it is the substrate that is converted to $\mathrm{NO}_{2}{ }^{-}$and $\mathrm{NO}_{3}{ }^{-}$during nitrification. Moreover, it was expected that where decomposition and $\mathrm{N}_{\min }$ are high, $\mathrm{N}_{\text {nit }}$ would be high resulting from the in situ production of $\mathrm{NH}_{4}{ }^{+} . \mathrm{N}_{\min }$ appeared as the primary influencing variable in each city and season (Table 3.5). $\mathrm{NH}_{4}{ }^{+}$was also a key driver across sites and seasons, however it was not selected in Baltimore-summer. The models selected for Baltimore-winter, Portland-summer, and Portland-winter had very high explanatory power $(>75 \%, \mathrm{p}<0.005)$. Nitrification can be an important source of $\mathrm{NO}_{3}{ }^{-}$in ecosystems, and these results suggest that this process is closely coupled with $\mathrm{N}_{\text {min }}$ patterns in BRF soils in this study. Thus, although not directly regulated by SOM quality, $\mathrm{N}_{\text {nit }}$ may be indirectly influenced by soil $\mathrm{C}: \mathrm{N}$ ratios due to the tight coupling between $\mathrm{N}_{\text {nit }}$ and $\mathrm{N}_{\min }$ that was observed in these soils. These results suggest the potential 
influence of the composition of soil organic content on N-cycling processes in BRFs. BRF soils are typically intentionally amended with compost to increase the organic matter content and water holding capacity of the soils.

\section{Respiration}

Respiration patterns were similar to DEA patterns: respiration rates were lower in winter and higher in summer in Baltimore, and rates were higher in winter and lower in summer in Portland, though not significantly different between seasons or city $(\mathrm{p}>0.05)$. There was, however, a significant interaction between city and season on respiration rates $(\mathrm{p}=0.042)$. Like $\mathrm{N}_{\min }$ and $\mathrm{N}_{\text {nit }}$, respiration rates increase with temperature and are highest at intermediate soil water contents (Robertson and Groffman 2015).

Selected multiple regression models showed interactions between respiration, SM, and MBC across seasons except for Baltimore-summer (Table 3.5). SOM was important during summer in both cities, and soil texture (as \% fines) also emerged as an important variable. The explanatory power of the resulting models was strong across all city and season pairs $(>73 \%)$.

\section{BRF maintenance}

During the summer sampling interval, the condition and maintenance of the sites was observed to be highly variable within and among cities. In particular, many BRFs in Baltimore had a prevalence of anthropogenic litter within the sites and some sites were overgrown. In response to this observed difference between cities, litter was collected and measured during winter sampling events, and the general upkeep of sites was noted. The 
volume of litter ranged from none to approximately 150 gallons in Baltimore, and none was observed in any sites in Portland. In many Baltimore BRFs, the vegetation was overgrown, and detritus and leaf litter ranged from inches to feet in depth. Portland had the opposite trend showing signs of recent vegetation trimming and no present detritus or leaf litter. While these differences in site condition were stark across and within cities, they did not have a discernable effect on soil $\mathrm{N}$-cycling processes. Baltimore BRF soils demonstrated low variability in N-cycling parameters relative to Portland BRF soils which varied considerably across the city, though DEA and respiration rates fell within similar ranges across cities. The presence of detritus and leaf litter in Baltimore facilities was not reflected in the SOM content, as SOM was low in Baltimore relative to Portland, and inorganic $\mathrm{N}$ content was similarly low in Baltimore. $\mathrm{N}_{\min }$ and $\mathrm{N}_{\text {nit }}$ rates were low relative to rates in Portland, however it is unclear how these patterns may be connected to broader-scale management activities. To date, no studies have evaluated the influence of maintenance activities such as detritus, leaf, and trash removal or vegetation trimming on the ecosystem functions within BRF. Future research observing possible interactions between management practices and $\mathrm{N}$-cycling patterns in BRFs may provide valuable information concerning how to relate management practices to desired ecological outcomes in BRFs.

While strong and relatively consistent relationships were observed between soil parameters and $\mathrm{N}_{\min }, \mathrm{N}_{\mathrm{nit}}$, and respiration rates despite the heterogeneity in site and environmental conditions across cities, relationships between DEA and soil parameters were more variable across cities and seasons. Average seasonal rates did not differ 
significantly within either city, suggesting that these processes may be less variable across seasonal conditions than was hypothesized. Despite similar rates of $\mathrm{N}$-cycling across seasons, the variability in runoff inputs to BRFs resulting from changes in rainfall across seasons may impact the relative $\mathrm{N}$ removal and transformation capacity of soil communities through time. Although this study assessed the potential drivers and regulating factors of these $\mathrm{N}$-cycling processes, the variability observed may be due to changing availability of resources or fluctuations in stressors that were not captured in this study.

Prior studies have suggested that GSI and BRFs may be hotspots of denitrification in the urban landscape similar to riparian zones acting as hotspots in the natural landscape (Zhu et al. 2004; Bettez and Groffman 2012). Because of the management implications of $\mathrm{N}$ retention and removal within BRFs, there may be interest in optimizing conditions to facilitate "hotspot" conditions and promote $\mathrm{N}$ removal. Studies have considered the efficacies of different sources of carbon substrates in facilitating denitrification processes, finding that higher $\mathrm{C}: \mathrm{N}$ ratios accommodated higher rates of denitrification (Kim et al. 2003). The results from the present study suggest that the quality of carbon substrate used in BRF design may have an impact on additional processes in the $\mathrm{N}$-cycle that regulate the form of $\mathrm{N}$, such as $\mathrm{N}_{\min }$ and $\mathrm{N}_{\text {nit }}$, as indicated by the observed relationships with microbial C:N. Carbon amendments and compost composition may also facilitate greater water holding capacity in soils (Bridgham et al. 1998; McPhillips and Walter 2015). 


\subsection{Conclusions}

This study surveyed potential denitrification, potential net nitrification, and potential net $\mathrm{N}$ mineralization in $9 \mathrm{BRF}$ in Portland, OR during summer and winter conditions to evaluate the seasonal and regional variability in soil bio-physiochemical properties and $\mathrm{N}$-cycling and identify drivers of the observed patterns across spatial and temporal contexts. Soil bio-physiochemical properties and N cycling rates showed different patterns in Baltimore and Portland, suggesting that BRFs may not function the same across regions. No differences in $\mathrm{N}$ cycling rates were observed between seasons, however results indicated that relationships between $\mathrm{N}$ cycling rates and controlling soil properties are dynamic, and limiting variables may change due to seasonal and environmental conditions.

In addition to the processes considered in this study, there are many other ecosystem functions, services, and co-benefits that may be provided by BRFs, such as carbon sequestration, temperature regulation and cooling to offset urban heat island effects, pollinator and insect habitat provision, and aesthetic benefits to communities (De Groot 2006). Conversely, there may be a number of concurrent disservices in BRFs, such as the unintended aesthetic outcomes of low-maintenance routines as observed in this study. Damp and thickly-vegetated habitats may be amenable to mosquitoes, rats, and other pests. Though the research considerations of these ecosystems is expanding quickly, there are still important knowledge gaps that must be addressed before these systems can be fully understood and optimized to support stormwater mitigation and other ecosystem services that benefit the communities in which they are constructed. 
These results suggest that BRFs may not function the same across regions, and a single-region assessment may not represent the variability in $\mathrm{N}$ cycling in BRFs across the US. To gain a more complete understanding of the variability of $\mathrm{N}$ cycling and the factors that impact the capacity of BRF soils to remove $\mathrm{N}$ from stormwater runoff, future research should consider a broader assessment of soil processes across regional and climatological contexts. The following study in this dissertation evaluates soil properties and $\mathrm{N}$ cycling in multiple cities across the United States that utilize BRFs in their stormwater management programs. 


\section{Multi-City Comparison of Soil bio-physiochemical properties and Nitrogen Cycling in Stormwater Bioretention Facilities in the United States}

\subsection{Introduction}

Green stormwater infrastructure (GSI) is comprised of a broad suite of stormwater management methods including bioretention facilities (BRFs), which are highly managed ecosystems constructed in urban landscapes across the United States. These types of stormwater retention systems are intended to mimic the functions of riparian zones that are lost to urbanization, including the collection, filtration, and infiltration of stormwater (Portland Stormwater Management Manual 2016). BRFs include a range of designs from small-scale, source-control structures to larger, end-of-pipe measures (German et al. 2005), and their spatial extent is rapidly expanding in many regions of the United States to address stormwater issues intrinsically related to urban development (Barbosa et al. 2012). The design and implementation of these sites varies across space, and different strategies are employed to fit the needs and requirements of each locale, such as sizing basins to manage regional precipitation patterns and prioritizing native vegetation (McPhillips and Matsler 2017). Despite variations in the site design process across locations, the general attributes of these systems are similar across BRF types. For example, infiltration and conveyance BRFs include designs such as swales, planters, and basins which have a basic design of surface vegetation, a growing medium (prepared soil mixture), gravel, and an underdrain or overflow discharge mechanism if the underlying soil does not meet infiltration standards (Portland Stormwater Management Manual 2016). Consequently, the engineering of the soil profile creates a forced geology that did not evolve under conditions that produced the native soils, and the design of the 
ecosystem coerces an ecology that does not represent a long-term relationship between the site and the environment (Kaushal and Belt 2012).

While BRFs have been shown to provide similar functions to riparian zones including infiltration of runoff to groundwater, mitigation of peak discharge to receiving surface waters, and nutrient attenuation, BRF design and landscape context differ markedly from these natural analogues. Symptomatic of their manmade physical structure, these systems are isolated in the urban environment and generally disconnected from surrounding soils by concrete barriers (Portland Stormwater Management Manual 2016), they have altered hydrology due to engineered soil profiles, and they receive supplies of urban pollutants from adjacent impervious surfaces (Kaushal and Belt 2012; McPhillips and Walter 2015).

Significant attention is being directed at evaluating BRF technology across disciplines, including assessments of hydrologic performance, social perceptions (Matthews et al. 2015), and ecosystem functions and services (Pataki et al. 2011). While not a primary design focus, nutrient cycling in BRFs is of interest as nitrogen $(\mathrm{N})$ is a ubiquitous water quality concern in many urban areas (Collins et al. 2010). Human activities have mobilized $\mathrm{N}$ in urban watersheds (Vitousek et al. 1997; Kaye et al. 2006) resulting from practices such as transportation, land use change, food and energy consumption, and residential lawn management (Law et al. 2004; Bettez and Groffman 2013; Rao et al. 2014), making watershed $\mathrm{N}$ retention a key concern for protecting urban surface waters from $\mathrm{N}$ pollution (Carpenter et al. 1998; Bernhardt et al. 2008). Riparian zones are well-documented N sinks (McClain et al. 2003; Vidon et al. 2010), and the 
design of BRFs may facilitate conditions that promote $\mathrm{N}$ removal via denitrification, including organic-rich soils and intermittent wetting-drying patterns (Groffman et al. 1988). A growing body of literature has addressed soil bio-physiochemical properties and $\mathrm{N}$ cycling dynamics within BRFs within regions (Zhu et al. 2004; Bettez and Groffman 2012; McPhillips and Walter 2015; Morse et al. 2017; Waller et al. 2018), however, little attention has been given to how these systems compare across regions or how they compare to the natural riparian zones they are designed to mimic. $\mathrm{N}$ cycling encompasses dynamic processes driven by environmental variables that fluctuate based on environmental conditions such as precipitation and temperature regimes (Groffman et al. 1988), and therefore, single-region measurements of $\mathrm{N}$ cycling parameters are not representative of continental trends in BRF soil biogeochemistry. Furthermore, while studies have compared single functions of BRFs to reference riparian areas (Bettez and Groffman 2012), these single metrics do not adequately capture whether and how BRF ecosystems and riparian ecosystems are distinctly different from one another.

The similarity of BRF design across regions with different climates and land-use histories reflects ideas laid out in the hypothesis of ecological homogenization (Groffman 2014) in the urban landscape which posits that urban land use change may be homogenizing ecosystems in the United States, producing landscapes that are more similar to one another than to the natural ecosystems they replace. This homogenization has the potential to have continental-scale effects on water, carbon, and nutrient dynamics (Groffman et al. 2014). The ecological homogenization hypothesis has largely focused on the role of residential lawns in homogenizing the landscape of urban America (Groffman 
et al. 2017; Wheeler et al. 2017; Locke et al. 2018), with less attention considering the spatial heterogeneity in urban GSI (Blaszczak et al.2018). However, the ubiquity and extent of BRFs as an urban feature and their impact on important ecosystem services in the urban landscape makes them an ideal lens through which to examine homogenizing practices in urban ecological management.

The objectives of this study were to describe patterns in $\mathrm{N}$ cycling in BRFs across the United States and to determine how BRF soils compare across regions and to the natural riparian areas they are designed to mimic. This study compares the prevailing BRFs implemented in different climatic regions of the conterminous United States, including Baltimore, MD, Charlotte, NC, New York City, NY, Portland, OR, Phoenix, AZ, and Syracuse, NY during the summer growing season. It was predicted that cities in climates with frequent and intermittent summer rainfall would demonstrate greater rates of $\mathrm{N}$ cycling in BRFs than cities with dry summer climates, and that BRFs will be more similar to one another than to riparian areas in their regions.

\subsection{Methods}

\section{Study Sites}

The goal of this study was to characterize soil $\mathrm{N}$ cycling in the prevailing BRF in each city and determine whether BRF soils demonstrate a unique ecological signature, distinct from that of analogous riparian areas. We selected six cities across the United States that utilize BRFs as a part of their stormwater management practices: Baltimore, 
MD (BLT), Charlotte, NC (CLT), New York City, NY (NYC), Portland, OR (PDX), Phoenix, AZ (PHX), and Syracuse, NY (SYR) (Table 4.1; Figure 4.1). 


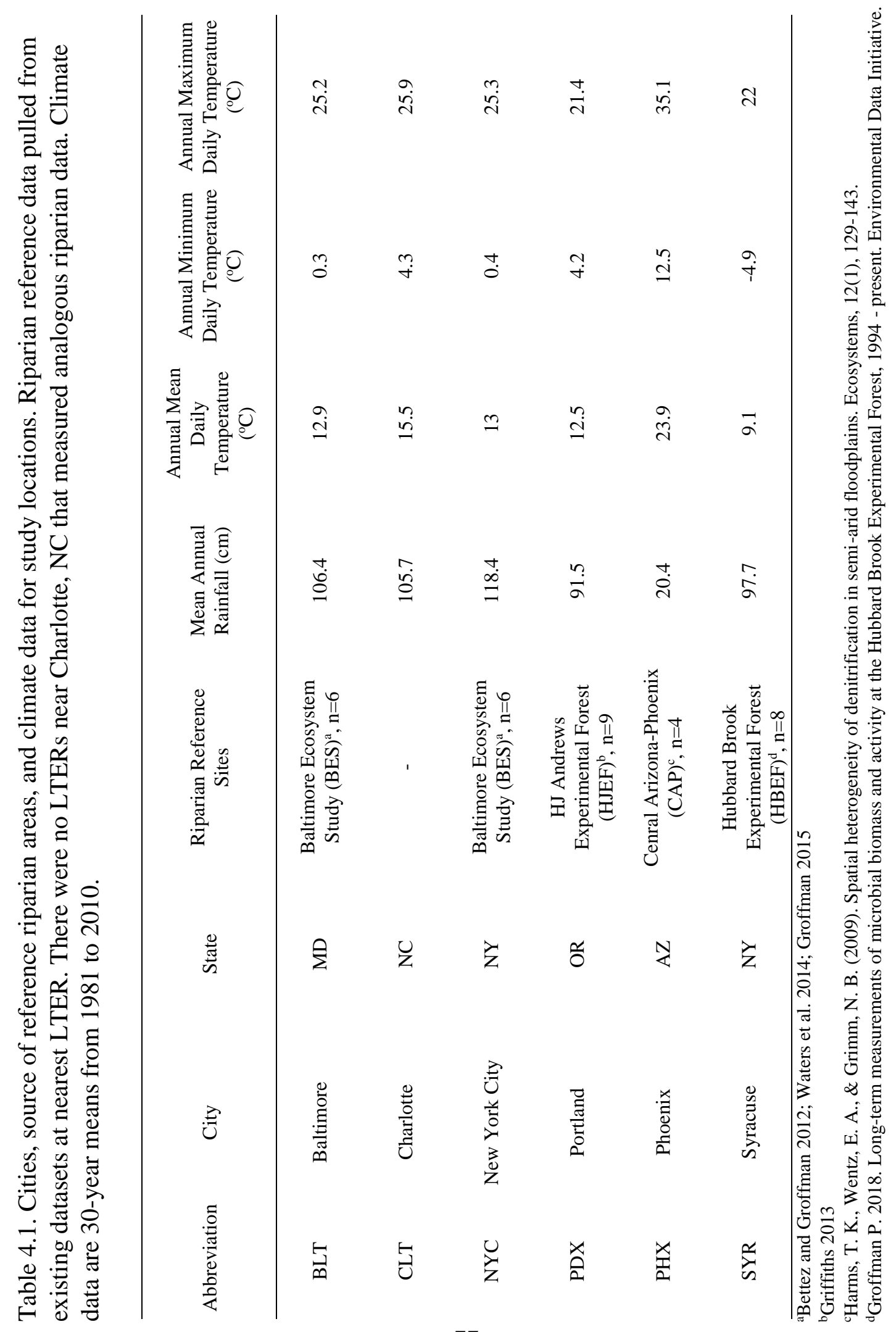




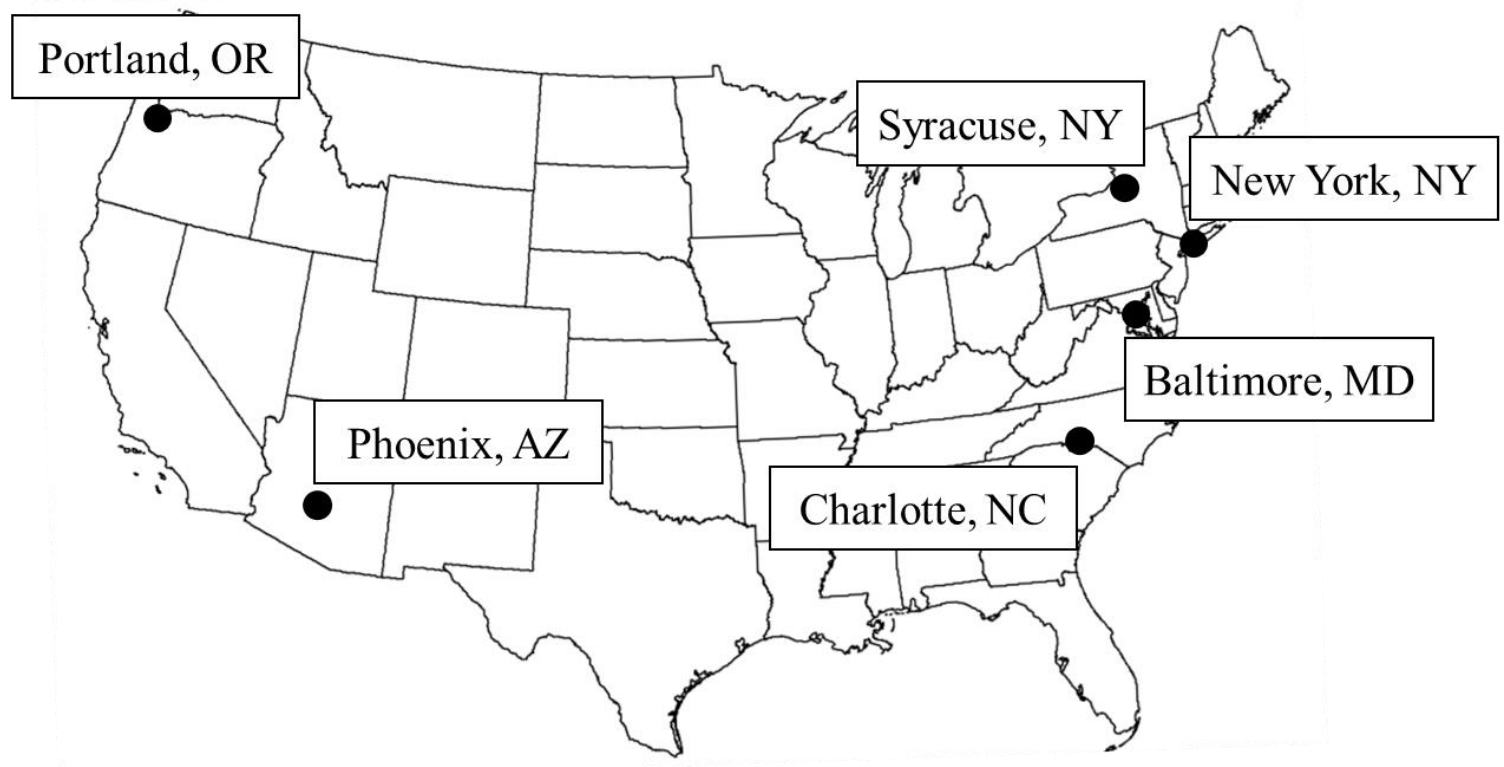

Figure 4.1. Locations of study cities: Baltimore, MD, Charlotte, NC, New York City, NY, Phoenix, AZ, Portland, OR, and Syracuse, NY.

We sampled six BRF sites in each city during July-September 2017 to capture dynamics of the growing season and distinct differences between summer climates across regions. This time frame captured the dry period of Portland's Mediterranean climate, Phoenix's monsoon season, Charlotte's tropical storm seasons, and the intermittent thunderstorms in the northeast (Figure 4.2). Design specifications across municipalities in different regions varied as a result of the need to regulate different precipitation patterns (volume and intensity) and water quality parameters, such that the dominant BRFs in PHX were sized to capture a few large storms while PDX sites were sized for high frequency, low intensity events. Thus we could not fully control for site design, leading to variability in BFR contributing areas, soils, and vegetation across the regions in our study. However, we limited sites to specific selection criteria to ensure that we were 
comparing similar ecosystems. Selection criteria included: intermittently dry sites (no pond- or wetland-type BRF selected), designed and constructed BRF (no managed natural ecosystems selected), small-scale $\left(<300 \mathrm{~m}^{2}\right)$, and BRFs that were adjacent to impervious areas.

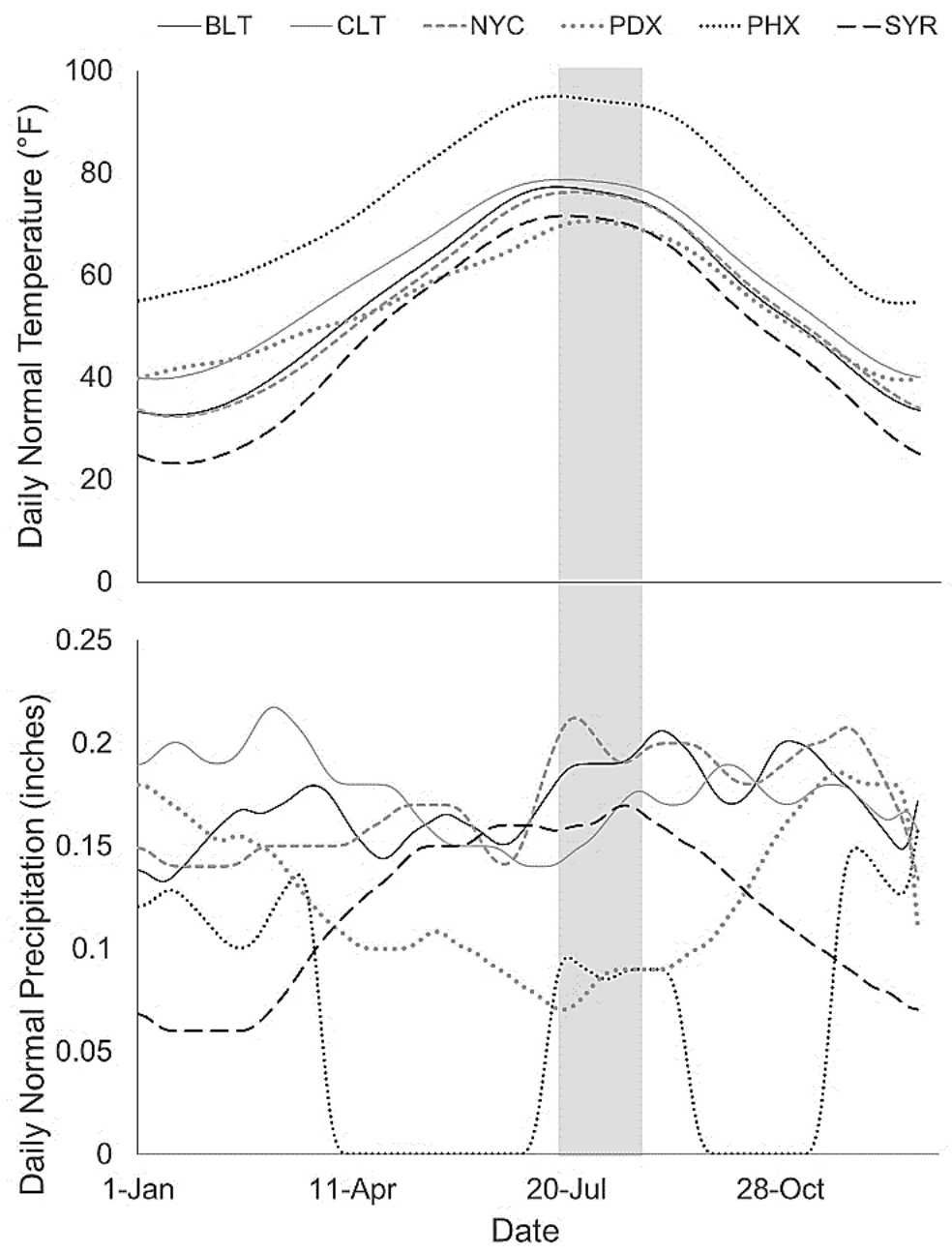

Figure 4.2. 10-year average daily temperature $\left({ }^{\circ} \mathrm{F}\right)$ and precipitation (in) for each city. Sampling period is indicated by gray bar (NCDC).

To compare BRF measurements to riparian areas, existing data from Long Term Ecological Research (LTER) sites was used for reference riparian areas. The LTER 
Network provides comprehensive, open access datasets from extended temporal and spatial scales that cover a diverse set of ecosystems. LTER sites closest to study locations were selected (Table 4.1). To ensure relative comparability between BRF and LTER measurements, LTER data was selected using the following criteria: sites must be in riparian or near-stream locations, riparian type must be herbaceous or forested (grassed riparian areas not selected) and non-manipulated, soil samples were collected no deeper than 6 inches in depth, samples were collected during summer sampling periods (JuneSeptember), and datasets must offer substantial overlap in terms of variables measured. Data points from different studies were permitted, however no site repetition was permitted. This resulted in data from Baltimore Ecosystem Study (BES), HJ Andrews Experimental Forest (HJEF), Central Arizona-Phoenix (CAP), and Hubbard Brook Experimental Forest (HBEF). There were no sites near Charlotte, NC that fit these criteria, thus Charlotte BRFs are not compared to riparian reference data. Additionally, there are no LTER sites closer to NYC than BES; therefore BES is used as reference data for both BLT and NYC.

\section{Field Methods}

At each BRF facility, a brief survey was completed to describe the present vegetation. Within each BRF facility, 4 soil cores were collected for soil characteristics and biogeochemical analyses. Soil cores were sampled to a depth of 6 inches using PVC

core tubes ( 2 inches in diameter). The 4 cores for soil bio-physiochemical properties and biogeochemical analysis were combined to form a single composite sample to characterize the spatial heterogeneity within each BRF facility. All samples were kept on 
ice in coolers and shipped overnight to Portland, OR, for analysis. Upon arrival, samples were immediately transferred to a refrigerator where they were stored at $4^{\circ} \mathrm{C}$ until processing.

\section{Laboratory Methods}

Soils were homogenized and subsampled and analyzed for soil biophysiochemical properties [soil moisture, soil organic matter (SOM), microbial biomass $\mathrm{C}$ and $\mathrm{N}$ (MBC and $\mathrm{MBC}$, respectively), inorganic $\mathrm{N}\left(\mathrm{NH}_{4}{ }^{+}\right.$and $\left.\left.\mathrm{NO}_{3}{ }^{-}\right)\right], \mathrm{N}$ cycling parameters [potential denitrification (DEA) potential net nitrification $\left(\mathrm{N}_{\text {nit }}\right)$, potential net mineralization $\left(\mathrm{N}_{\min }\right)$ ], and potential respiration.

Denitrification enzyme activity (DEA) was analyzed to determine soil potential denitrification rates. We used the chloramphenicol-amended acetylene-block method to measure potential denitrification rates (Tiedje et al. 1989). Triplicate soil slurries were created with $10 \mathrm{~g}$ soil and $10 \mathrm{~mL}$ DI water amended with additional $\mathrm{NO}_{3}^{-}$(as $\mathrm{KNO}_{3}$ ) and labile carbon (as dextrose) in $125 \mathrm{~mL}$ glass flasks capped with septa. We added chloramphenicol, an antibiotic that inhibits the production of new enzymes, allowing for denitrification rates measured in bottle assays to be more representative of denitrification activity at the time of sampling (Smith and Tiedje 1979). The flasks were purged with dinitrogen to remove oxygen and force anaerobiosis. We injected pure acetylene gas into the sealed, anoxic microcosms through septa caps using a syringe. Acetylene inhibits the conversion of $\mathrm{N}_{2} \mathrm{O}$ to $\mathrm{N}_{2}$ by blocking the activity of nitrous oxide reductase, allowing the measurement of $\mathrm{N}_{2} \mathrm{O}$ accumulation to estimate denitrification rates. 
Slurries were incubated at room temperature $\left(22^{\circ} \mathrm{C}\right)$ for 3 hours, and three $5-\mathrm{mL}$ gas samples were removed from the bottle headspaces at 45 -minute intervals throughout the incubation to measure $\mathrm{N}_{2} \mathrm{O}$ production over time. Flasks were continually mixed on a shaker table set at $125 \mathrm{rpm}$ between measurements to equilibrate $\mathrm{N}_{2} \mathrm{O}$ between the gas and aqueous phases. Gas samples were analyzed immediately by gas chromatography by manually injecting the $5 \mathrm{~mL}$ sample directly into a Shimadzu GC-2014 equipped with a 2 m Porapak Q column and a ${ }^{63} \mathrm{Ni}$ electron capture detector. Concentrations were corrected for $\mathrm{N}_{2} \mathrm{O}$ solubility in the aqueous phase using the temperature-dependent Bunsen coefficient based on ambient laboratory temperature (Knowles 1979). The linear rate of $\mathrm{N}_{2} \mathrm{O}$ production was used to determine the rate of denitrification within each microcosm. Only time periods representing linear production of $\mathrm{N}_{2} \mathrm{O}$ were used for calculations due to potential interference of bottle effects (Groffman and Tiedje 1989). DEA rates were scaled to soil dry-mass $\left(\mathrm{mg}-\mathrm{N} \mathrm{g}\right.$-soil $\left.{ }^{-1} \mathrm{~h}^{-1}\right)$ to determine the flux of $\mathrm{N}$ per unit mass of soil, allowing comparisons across soils of contrasting physical properties.

We determined soil moisture by drying subsamples at $105^{\circ} \mathrm{C}$ for 24 hours, and SOM by loss on ignition at $550^{\circ} \mathrm{C}$ for 4 hours. Microbial biomass $\mathrm{C}$ and $\mathrm{N}$ were measured using the chloroform fumigation incubation method (Jenkinson and Powlson 1976). Samples were fumigated with chloroform to kill and lyse microbial cells (releasing cellular $\mathrm{C}$ and $\mathrm{N}$ ), fumigated soils were inoculated with fresh $0.2 \mathrm{~g}$ soil, and all pairs of fumigated and unfumigated control samples were incubated at $25^{\circ} \mathrm{C}$ for 10 days. During the incubation, microorganisms lysed by chloroform were mineralized to $\mathrm{CO}_{2}$ and $\mathrm{NH}_{4}{ }^{+}$. Prior to and following incubation, extractable $\mathrm{NH}_{4}{ }^{+}$and $\mathrm{NO}_{3}{ }^{-}$were measured in 
fumigated and control soil by incubating soil with $2.0 \mathrm{M} \mathrm{KCl}$ solution on a shaker table at $125 \mathrm{rpm}$ for one hour to release bound ions into solution. The supernatant was filtered through $2.5 \mu \mathrm{m}$ Whatman filters using gravimetric filtration. Filtered samples were analyzed on a SmartChem Analyzer (Unity Scientific, NJ), using the salicylate method for $\mathrm{NH}_{4}{ }^{+}$and the cadmium reduction method for $\mathrm{NO}_{3}{ }^{-}$. The amounts of $\mathrm{CO}_{2}$ and $2 \mathrm{M} \mathrm{KCl}-$ extractable inorganic $\mathrm{N}$ produced in the fumigated soils during the incubation are proportional to $\mathrm{C}$ and $\mathrm{N}$ contents of soil microbial biomass. The amount of $\mathrm{CO}_{2}$ produced in the unfumigated control samples was used to estimate microbial respiration. Inorganic $\mathrm{N}\left(\mathrm{NH}_{4}{ }^{+}\right.$and $\left.\mathrm{NO}_{3}{ }^{-}\right)$in pre- and post-incubation control soils were used to calculate potential net $\mathrm{N}$ mineralization (production of inorganic $\mathrm{N}$ ) and potential net nitrification (transformation of $\mathrm{NH}_{4}{ }^{+}$to $\mathrm{NO}_{3}{ }^{-}$via net change in $\mathrm{NO}_{3}{ }^{-}$). Soil $\mathrm{pH}$ was determined by equilibrating $15 \mathrm{~g}$ of soil with $30 \mathrm{~mL}$ DI water at room temperature for 30 minutes. Following equilibration, $\mathrm{pH}$ readings were taken from duplicate soil samples from each site using a Thermo Scientific Orion Star A111 pH benchtop meter (Thermo Fisher Scientific, Waltham, MA).

\section{Statistical Methods}

The Shapiro-Wilk test was used to verify the normality of data. No parameters followed a normal distribution, so Box-Cox transformations were used to induce normality across all variables. To describe BRF $\mathrm{N}$ cycling patterns in each city, one-way analysis of variance (ANOVA) with Tukey honestly significant difference (HSD) pairwise comparison was performed on transformed variables to evaluate differences among soil bio-physiochemical properties and $\mathrm{N}$ cycling measurements across cities. 
Simple linear regressions were performed on transformed data to test relationships between $\mathrm{N}$ cycling parameters and hypothesized causal variable. Since certain statistical analyses are incompatible with negative values, flux measurements $\left(\mathrm{N}_{\min }\right.$ and $\left.\mathrm{N}_{\mathrm{nit}}\right)$ that have positive and negative values were scaled using unity-based normalization.

To understand the variation among BRF soil condition and ecology, nonparametric multivariate techniques were used to describe the similarities or differences among cities and how BRFs compare to natural riparian areas in each region. Non-metric multidimensional scaling (NMDS) was used to visualize and describe the inter-city and BRF-riparian variance in soil attributes. NMDS is a multivariate unconstrained ordination technique that presents the dissimilarity between communities (soil ecology profiles in this study) of individual sites within an ordination space. Unlike parametric multivariate analyses, such as principal component analysis, NMDS assumes no particular relationships between variables which reduces the need to transform data that could lead to distortions in the relationships between communities (Clarke 1993). As input variables to the NMDS, the soil bio-physiochemical properties and $\mathrm{N}$ cycling parameters matrices were combined into a set of parameters referred to in this study as the soil ecology fingerprint. Bray-Curtis dissimilarity was used, and rank dissimilarities were fitted into an ordination with dimensionality determined through a series of permutation tests that were used to isolate the ordination with the least stress (McCune and Grace 2002). Analysis of similarity (ANOSIM) was performed on the Bray-Curtis dissimilarity rank distance matrices with study site (City for BRF matrix, City/LTER location for BRF-riparian comparison) as a categorical predictor to determine the degree 
of similarity between cities and sites. Similar to ANOVA, ANOSIM is a hypothesis test that is used to evaluate a dissimilarity matrix rather than raw data. The ANOSIM statistic compares the mean of the ranked dissimilarities between groups to the mean of ranks dissimilarities between groups. R values near 1.0 suggest dissimilarity between groups, and $\mathrm{R}$ values near 0 indicates an even distribution of high and low ranks within and between groups, suggesting a higher degree of similarity between groups (Clarke 1993). The dimension-reduction capabilities of NMDS and the hypothesis testing in ANOSIM are complementary approaches in evaluating nonparametric data. All statistical analyses were performed in R version 3.5.2 (R Development Core Team 2008).

\subsection{Results and Discussion}

\section{Habitat and soil conditions}

Vegetation type was similar in BRFs across all cities except for PHX, which showed characteristically xeric vegetation. The dominant vegetation included rush, sedge, tall grasses, shrubs, some ornamental flowers, and trees (oak, birch, elm, dogwood, alder) in all cities but PHX. The dominant xeric vegetation present in PHX sites included agave, cacti, grasses, aloe, shrubs, and trees (mesquite, palo verde). Soil bio-physiochemical properties were highly variable among and within cities (Table 4.2). Soil moisture ranged from 3.3-69.4\%, SOM ranged from 1.1-20.1\%, $\mathrm{NO}_{3}{ }^{-}$ranged from $0.29-168.11 \mathrm{ug}-\mathrm{N} / \mathrm{g}-$ soil, and $\mathrm{NH}_{4}{ }^{+}$ranged from $0.74-53.80 \mathrm{ug}-\mathrm{N} / \mathrm{g}$-soil. Overall, the highest values for most parameters were found in $\mathrm{NYC}$, except for MBC (highest in PDX) and $\mathrm{NH}_{4}{ }^{+}$(highest in BLT and CLT). Average $\mathrm{NO}_{3}{ }^{-}$concentrations were 3.5-12 times higher and $\mathrm{NH}_{4}{ }^{+}$was lowest in NYC relative to the other cities. Across all cities, soil moisture was 
significantly positively correlated with $\operatorname{SOM}\left(\mathrm{r}^{2}=0.31, \mathrm{p}<0.0005\right)$, possibly resulting from decreased mineralization and subsequent accumulation of SOM under wetter conditions or SOM increasing the water-holding capacity in soils (Bridgham et al. 1998; McPhillips and Walter 2015).

\section{$N$ cycling parameters}

Mean DEA rates ranged widely across cities, from 0.007 to $5.05 \mathrm{ug}-\mathrm{N} / \mathrm{g}$-soil/hr (Table 4.3; Figure 4.3). DEA was significantly higher in NYC than other cities $(\mathrm{p}<0.05)$ with no differences between other cities. Excluding NYC, the range in DEA rates was 0.007 to $1.10 \mathrm{ug}-\mathrm{N} / \mathrm{g}$-soil/hr among the other cities.

Average DEA rates in all cities besides NYC were comparable to measurements of DEA rates in dry stormwater retention and detention systems across regions. Observed DEA rates in these sites have been $0.74 \mathrm{ug}-\mathrm{N} / \mathrm{g}$-soil/hr in grassed dry detention basins in Arizona (Zhu et al. 2004); 0.18-1.14 ug-N/g-soil/hr across a range of dry stormwater control types (dry detention ponds, infiltration basin, extended dry detention) in Maryland (Bettez and Groffman 2012); 0.23 ug-N/g-soil/hr in dry basins (McPhillips and Walter 2015); and below 0.30 ug-N/g-soil/hr in grassed and landscaped BRFs along the mid-Atlantic region (Waller et al. 2018). The high rates observed in NYC are comparable to rates observed in permanently wet stormwater retention systems (McPhillips and Walter 2015). Waller et al. (2018) found significantly higher rates in 
BRF sites that were overgrown and unmaintained, suggesting this could be a factor influencing NYC's high rates; however, this hypothesis does not extend to overgrown sites in BLT in which DEA rates were lower compared to the other cities.

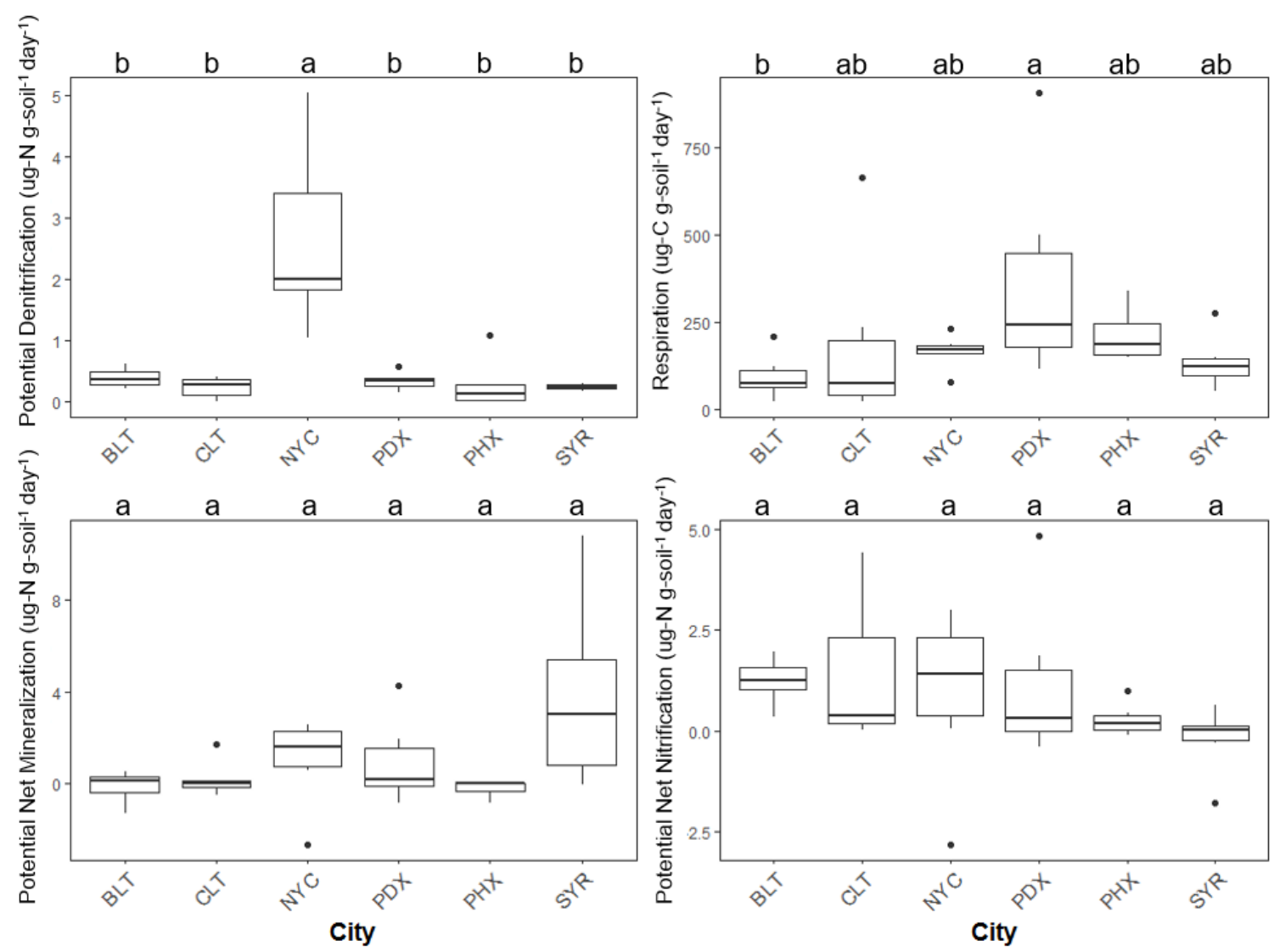

Figure 4.3. Average A) potential denitrification, B) respiration C) potential net Nmineralization, and D) potential net nitrification in each city during summer 2017. Letters indicate differences among sites as determined by one-way ANOVA with Tukey HSD post hoc analyses. 


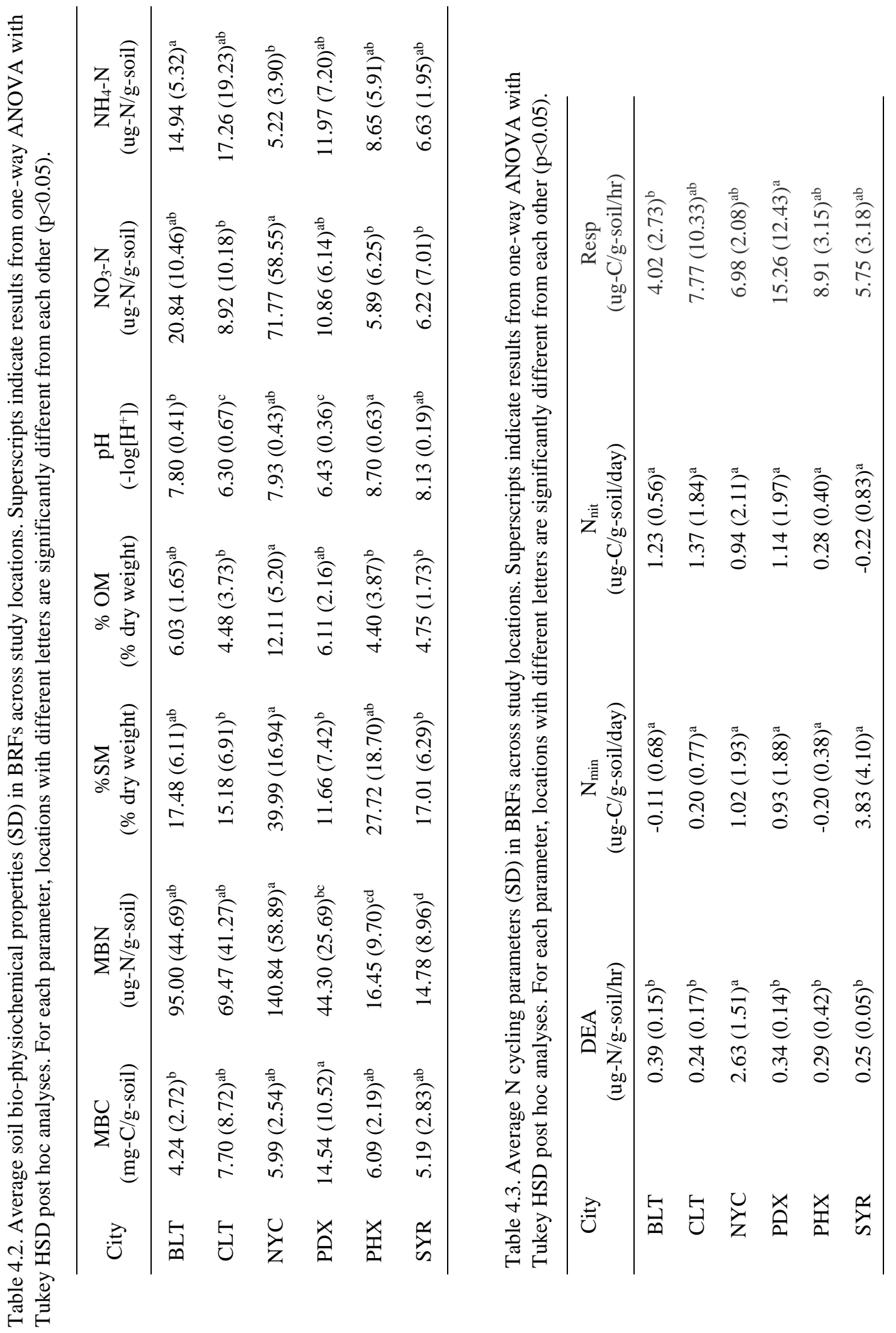


DEA increased with higher soil moisture $\left(\mathrm{r}^{2}=0.32, \mathrm{p}<0.0005\right), \mathrm{SOM}\left(\mathrm{r}^{2}=0.63\right.$, $\mathrm{p}<0.0001), \mathrm{NO}_{3}^{-}\left(\mathrm{r}^{2}=0.22, \mathrm{p}<0.005\right)$, and $\mathrm{MBN}\left(\mathrm{r}^{2}=0.38, \mathrm{p}<0.0001\right)$ consistent with trends observed in other studies examining soils in green stormwater systems (Bettez and Groffman 2012; McPhillips and Walter 2015). Denitrification rates have been shown to have a hysteretic response to soil moisture under wetting and drying cycles, with denitrification dramatically decreasing when soils dry from saturation to field capacity and increasing rapidly upon rewetting (Groffman and Tiedje 1988). Additionally, pulses of $\mathrm{C}$ and $\mathrm{N}$ mineralization have been observed following these changes in soil moisture (Birch 1964; Groffman and Tiedje 1988). Samples were not collected at the same interval following a rain event, however the positive relationship between SOM and soil moisture suggests that drying rates may be affected by the organic content of soils (Hudson 1994). It follows that the high SOM present in NYC may slow the rate of drying between precipitation events, thus maintaining high rates of denitrification during intermittent dry periods.

Potential denitrification is an integrative measure of the maximum capacity of the microbial community in the soil to remove nitrate. The assay integrates long-term variability in the controlling factors in the denitrification process by removing limitations to the reaction, thus making it a useful tool to compare ecosystems across contexts (Bettez and Groffman 2012). The existing microbial community reflects the recent history of environmental conditions that has shaped the current community composition, and changes in DEA over time can indicate changes in microbial community function in response to changes in the environment (McGill 2010). Higher DEA rates in NYC 
relative to other cities corresponds to higher soil moisture, $\mathrm{SOM}$, and $\mathrm{NO}_{3}{ }^{-}$in $\mathrm{NYC}$ BRFs.

$\mathrm{N}_{\min }$ ranged from -2.64 to $10.79 \mathrm{ug}-\mathrm{N} / \mathrm{g}$-soil/day with no significant differences across sites (Figure 4.3). The high end point represents one SYR site with a rate 1-4 orders of magnitude higher than all other observations. Negative $\mathrm{N}_{\min }$ rates represent a greater degree of immobilization (conversion of $\mathrm{N}$ into organic forms) than of mineralization (conversion of $\mathrm{N}$ into inorganic forms) and were observed in at least one site in each city. Low mineralization values were associated with low MBC:MBN ratios (the $\mathrm{C}: \mathrm{N}$ content of the microbial fraction). The largest negative values of $\mathrm{N}_{\min }$ representing the greatest degree of $\mathrm{N}$ immobilization were observed with the lowest MBC:MBN ratios, though these relationships were not statistically significant. Despite the relationship between SOM and soil moisture and the potential causal mechanism of $\mathrm{N}$-mineralization in this relationship, $\mathrm{N}_{\min }$ did not demonstrate discernable patterns or relationships with other variables, and no significant patterns emerged from $\mathrm{N}_{\min }$ among cities.

$\mathrm{N}_{\text {nit }}$ ranged from -2.82 to $4.84 \mathrm{ug}-\mathrm{N} / \mathrm{g}$-soil/day with no significant differences across sites (Figure 4.3). $\mathrm{N}_{\text {nit }}$ rates were significantly positively correlated with $\mathrm{NH}_{4}-\mathrm{N}$ concentrations $\left(\mathrm{r}^{2}=0.47, \mathrm{p}<0.0001\right)$, the substrate in the oxidation of $\mathrm{NH}_{4}{ }^{+}$to $\mathrm{NO}_{3}{ }^{-}$. Nitrification can provide an important supply of $\mathrm{NO}_{3}{ }^{-}$in $\mathrm{NO}_{3}{ }^{-}$-limited systems (Reddy and Patrick 1984), however these results suggest that $\mathrm{N}_{\text {nit }}$ does not supply a major source of $\mathrm{NO}_{3}{ }^{-}$to $\mathrm{BRF}$ soils. Nitrification has also been shown to have a hysteretic response to soil wetting-drying cycles (Stark and Firestone 1995), however, $\mathrm{N}_{\text {nit }}$ was not different 
across cities and there was no relationship to soil moisture, suggesting a more complex relationship between nitrification processes and soil bio-physiochemical properties.

Respiration rates ranged from 1.03 to $37.0 \mathrm{ug}-\mathrm{C} / \mathrm{g}$-soil/hr with the highest rates occurring in PDX, the lowest rates occurring in BLT $(\mathrm{p}<0.05)$, and no differences among other sites (Figure 4.3). Measurements of respiration rates in BRFs are limited, but Bettez and Groffman (2012) observed higher respiration rates in dry-type stormwater systems in Maryland. Though respiration is not a direct factor in the N-cycle, respiration rates can indirectly inform processes affecting $\mathrm{N}$ transformations. Respiration moderates the available $\mathrm{C}$ and $\mathrm{O}_{2}$ content of the soils, and respiration patterns may be useful in understanding soil metabolic activity in nonsaturated conditions. Respiration patterns differed from those of DEA, with the driest site, PDX, demonstrating the highest rates. Respiration rates have shown to be less sensitive than denitrification processes to soil drying phases, and they have a direct impact on the $\mathrm{O}_{2}$ content of soils (Groffman and Tiedje 1988). Higher respiration rates have the potential to deplete soil $\mathrm{O}_{2}$ concentrations in soil microsites, promoting anaerobic conditions that facilitate denitrification (Zhu et al. 2004). However, during extended dry periods, particularly in regions that receive little summer rainfall such as Portland, high rates of respiration are unlikely to induce anoxia.

The hydrologic pulse dynamics of intermittent sustained flooding of BRF soils may have variable impacts on soil $\mathrm{N}$ and respiration processes, regulated by the organic content of the soils and related water-holding capacity. Pulsed denitrification fluxes may be high following precipitation events and subsequent soil rewetting in BRF soils as a combined result of 1) elevated respiration rates that deplete soil $\mathrm{O}_{2} ; 2$ ) high $\mathrm{NO}_{3}{ }^{-}$ 
concentrations from $\mathrm{N}$ mineralization and nitrification during dry conditions, $\mathrm{N}$ mineralization during the rewetting event, or $\mathrm{NO}_{3}{ }^{-}$supplied in runoff (Peterjohn and Schlesinger 1991; Zaddy et al. 1996; Belnap et al. 2004; Zhu et al. 2004). The high denitrification fluxes associated with rewetting events cannot be sustained in moisturelimited conditions without a mechanism for increasing the capacity for moisture retention. The results in this study suggest that highly organic soils may have to potential to sustain high denitrification rates during intermittent dry periods.

\section{Comparative analysis of BRFs and riparian areas}

Though data were not available for all variables across the LTER riparian sites, high variability in soil bio-physiochemical properties among and within LTER riparian sites were observed (Table 4.4). Soil moisture ranged from 8.7 to $74.0 \%$, SOM ranged from 1.7 to $87.5 \%, \mathrm{NO}_{3}{ }^{-}$ranged from 0.16 to $23.7 \mathrm{ug}-\mathrm{N} / \mathrm{g}$-soil, and $\mathrm{NH}_{4}{ }^{+}$ranged from 0 to $24.0 \mathrm{ug}-\mathrm{N} / \mathrm{g}$-soil. Similarly, N cycling and respiration rates showed high variability across locations. DEA rates in the LTER riparian sites ranged from 0 to $3.31 \mathrm{ug}-\mathrm{N} / \mathrm{g}$ soil/hr (Table 4.5). $\mathrm{N}_{\min }$ and $\mathrm{N}_{\text {nit }}$ ranged from -0.8 to 19.1 and 0 to $12.3 \mathrm{ug}-\mathrm{N} / \mathrm{g}$-soil/day, respectively. Potential respiration ranged from 1.7 to $245.0 \mathrm{ug}-\mathrm{C} / \mathrm{g}$-soil/day. 


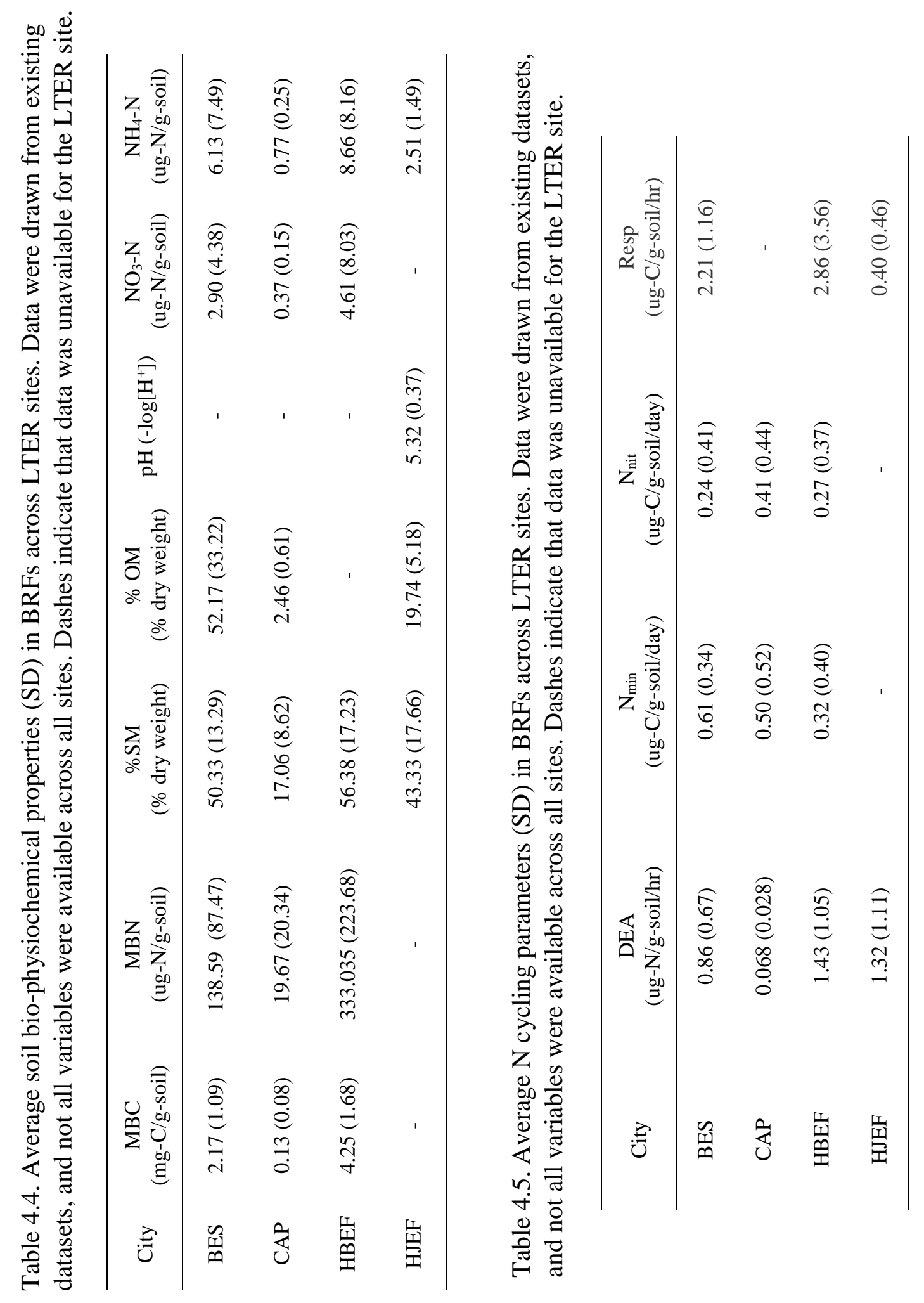


The NMDS ordination of BRF soil ecology fingerprint across cities produced a two dimensional ordination with low stress $(\mathrm{S}=0.007)$ (Figure 4.4). The soil ecology fingerprint was not discriminated across either axis by city, and there was significant overlap across all cities (ANOSIM: $\mathrm{R}=0.015, \mathrm{p}=0.329$ ). This indicates that the soil ecology profile did not significantly differ across the study sites, and BRFs did not show stratification across geographical regions. Despite NYC displaying a distinct pattern of elevated DEA, SOM, and soil moisture, the remainder of the measured variables were not distinctly different in NYC, and the overall soil ecology profile was not significantly different among other cities.

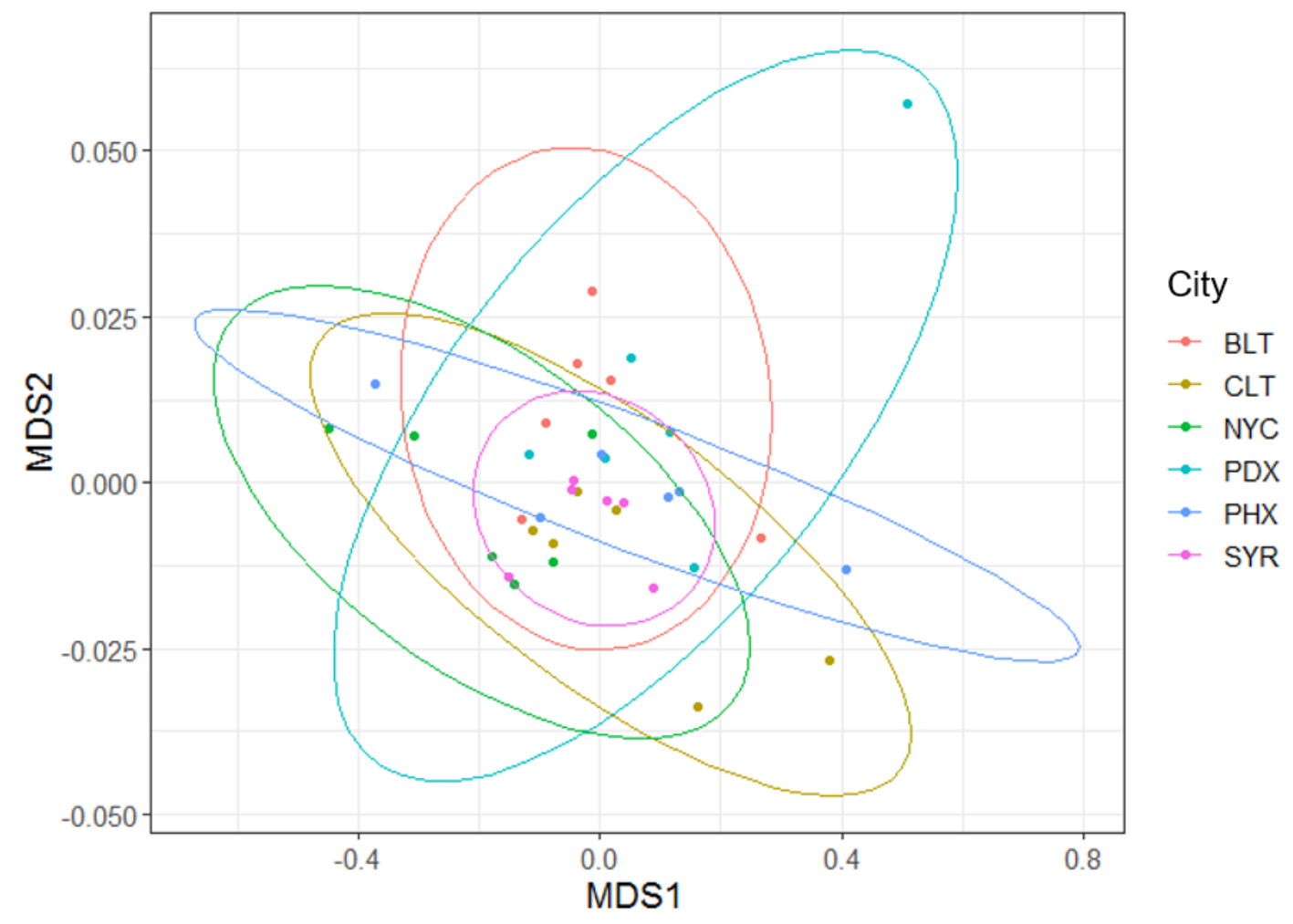

Figure 4.4. Non-metric multidimensional scaling (NMDS) ordination of BRF in all cities using soil bio-physiochemical properties and $\mathrm{N}$ cycling parameters as the measures analyzed and mapped (stress=0.005). Ellipses represent the $95 \%$ confidence interval around the centroid of each city. 
The NMDS ordination of paired BRF and riparian areas in LTER sites yielded mixed results. All BRFs showed significant differences from riparian areas except for SYR and HBEF (Figure 4.5; Table 4.6). Although PHX and CAP riparian areas were identified as significantly different, the stress was very low in the NMDS ordination, indicating that the low number of data points may not be sufficient to full describe the patterns across the two sites.
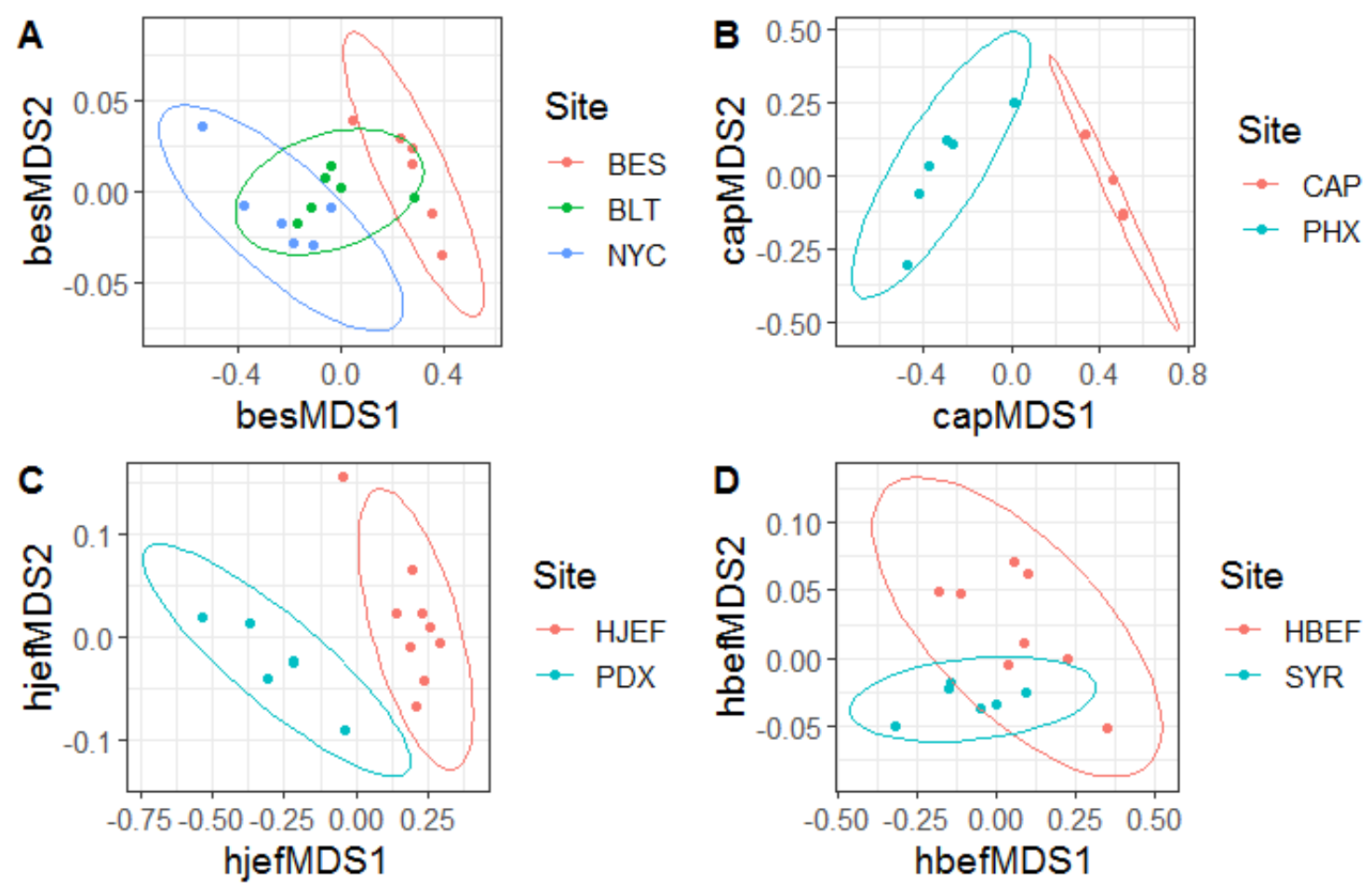

Figure 4.5. Non-metric multidimensional scaling (NMDS) ordination paired BRF and riparian areas: A) BLT-BES and NYC-BES; B) PHX-CAP; C) PDX-HJEF; and D) SYRHBEF using soil bio-physiochemical properties and $\mathrm{N}$ cycling parameters as the measures analyzed and mapped (stress $=0.005$ ). Ellipses represent the $95 \%$ confidence interval around the centroid of each site. The greater the degree of ellipses overlap, the more similar are the sites, and the more distant the ellipses, the more different are the sites. LTER sites are shown in red, and BRF sites are shown in blue and green. 
Table 4.6. Analysis of similarity (ANOSIM) results for paired BRF-riparian area comparisons. Asterisks indicate pairs that were significantly different.

\begin{tabular}{ccccc}
\hline $\begin{array}{c}\text { BRF } \\
\text { Location }\end{array}$ & $\begin{array}{c}\text { Paired Riparian Area } \\
\text { Location }\end{array}$ & Stress & $\mathrm{R}$ & $p$ \\
\hline BLT & BES & 0.001 & 0.49 & $0.017^{*}$ \\
NYC & BES & 0.001 & 0.83 & $0.004^{*}$ \\
PDX & HJEF & 0.005 & 0.89 & $0.002^{*}$ \\
PHX & CAP & $<0.0001$ & 0.95 & $0.006^{*}$ \\
SYR & HBEF & 0.019 & 0.13 & 0.13 \\
\hline
\end{tabular}

These results suggest that BRFs may have a distinct signature relative to their natural riparian analogues as BRF soil ecology profiles were significantly different from their paired riparian reference sites for all cities except for SYR. The general design and implementation of BRFs renders them inherently different than nearby natural riparian zones: they are isolated and generally disconnected from surrounding soils and water tables by concrete barriers (Portland Stormwater Management Manual 2016), they have an altered hydrology due to engineered soil profiles, they experience intensified hydrologic pulse dynamics as they drain runoff from impervious catchments (Zhu et al. 2004), and they receive supplies of urban pollutants from adjacent impervious surfaces.

However, as has been seen in this study and previous chapters, soil ecological functions are dynamic through time, and the temporal separation between BRF and LTER riparian measurements may be artificially segregating sites in these analyses. Moreover, the power in this study is low and may not be fully representative of nationwide patterns; however, the patterns observed here merit further investigation in 
comparative studies of BRF and riparian zones across regions to further explore the hypothesis that BRF is a mechanism of ecological homogenization in the United States.

\subsection{Conclusions}

The objective of this study was to characterize soil $\mathrm{N}$ cycling in the prevailing BRF in each city and determine whether BRF soils demonstrate a unique ecological signature, distinct from that of analogous riparian areas. The results of this study suggest that BRF soils in each city are broadly functioning similarly in terms of $\mathrm{N}$ cycling rates. NYC demonstrated a distinct pattern of high rates of potential denitrification that were likely due to coupled SOM and soil moisture properties. However, there was high overlap in potential denitrification rates among other cities, and other $\mathrm{N}$ cycling parameters did not show differences across cities.

BRFs across cities showed significant overlap of soil ecological variables in a reduced-dimension ordination space (NMDS) but were distinctly different when compared to natural riparian areas in each region. These results show some of the first evidence of ecological homogenization processes in BRFs, and future research should consider these patterns more in depth by performing concurrent studies in BRFs and natural floodplains or riparian areas, expanding investigations to consider other types of GSI and the natural models for these systems. An understanding of broad homogenization processes in GSI can lead to more accurate predictions of GSI nutrient and pollutant removal processes and can inform regional and national scale biogeochemical processes as urban centers across the United States continue to expand. As urban centers continue to expand and become denser, many will face similar 
challenges in managing and mitigating the effects of stormwater. An understanding of the regional behavior in BRFs and other types of GSI can inform whether strategies can be generalized across space to manage similar or diverging management needs. 


\section{Conclusions}

To date, research investigating $\mathrm{N}$ cycling in BRFs and other types of GSI has shown that these ecologically-based stormwater management systems may be denitrification hotspots in the landscape with a higher potential for denitrification than natural riparian areas (Zhu et al. 2004; Bettez and Groffman 2012), however, there is a distinction in N removal capacity between design types: wet-type designs that are permanently inundated, such as ponds and wetlands, have been shown to have a higher capacity for $\mathrm{N}$ removal via denitrification relative to dry-type designs such as the BRFs studied in this dissertation (Bettez and Groffman 2012; McPhillips and Walter 2015; Morse et al. 2017). In addition to the influence of the hydrologic properties of these systems (wet vs dry), studies have identified the importance of SOM in regulating $\mathrm{N}$ cycling processes mechanistically through mediating soil water holding capacity (and thus soil redox conditions) (Rawls et al. 2003; McPhillips and Walter 2015) and functionally through the provision of carbon sources for the $\mathrm{N}$ transformation reactions (Bettez and Groffman 2012; Waller et al. 2018; Deeb et al. 2018). Other design properties including vegetation type and soil depth have been shown to influence the extent to which BRFs can removal $\mathrm{N}$ via denitrification (Waller et al. 2018). These studies have largely focused on the influence of specific design differences in BRFs; however, these studies do not account for the potential sources of variability that occur through space and time that may impact $\mathrm{N}$ cycling processes. Broad-scale environmental conditions, such as climate and weather patterns, that regulate processes in the $\mathrm{N}$ cycle (soil moisture, organic matter, microbial biomass, and soil nutrient content) are likely to change across regions and through time 
(Groffman et al. 1988). Therefore, there is not yet a complete picture of $\mathrm{N}$ cycling dynamics in BRFs as the relationships described in the research to-date do not consider the possible variability in processes across climatic and seasonal conditions.

\subsection{Key findings}

This dissertation expands upon the important foundational research that has identified patterns of $\mathrm{N}$ cycling processes in BRF in the United States. This research presented in this dissertation investigated how $\mathrm{N}$ cycling processes in BRFs vary through time and space by considering the influence of different seasonal conditions and regional settings on soil bio-physiochemical properties and $\mathrm{N}$ cycling processes. Four important spatiotemporal themes emerged:

- Seasonal variability was not a primary influence in $\mathrm{N}$ cycling process rates, but $\mathrm{N}$ removal efficiencies may change with higher and lower depths of seasonal precipitation,

- Soil saturated hydraulic conductivity category (low vs high $\mathrm{K}_{\text {sat }}$ ) influenced $\mathrm{N}$ cycling processes,

- Maintenance (or lack thereof) did not impact $\mathrm{N}$ cycling processes or soil biophysiochemical properties, and

- BRF soils showed more similarity to other BRFs across regions than to natural riparian areas within each region. 


\subsection{Seasonal variability}

Seasonal variability was not a primary influence in $\mathrm{N}$ cycling process rates in Baltimore, MD or Portland, OR. However, the relationships between $\mathrm{N}$ cycling variables and soil bio-physiochemical properties changed across seasonal conditions. Different variables emerged as important regulating factors in summer and winter conditions, suggesting that there could be potential limitations to $\mathrm{N}$ cycling processes across different seasonal conditions. In this study, however, potential $\mathrm{N}$ cycle rates were investigated in which limitations are removed during analyses, and these results are an indication of the capacity of the system to perform these processes rather than the in situ process rates. Due to the contrasting seasonal precipitation patterns in Portland, OR, BRF soils demonstrated distinctly different $\mathrm{N}$ removal efficiencies in summer and winter. Results showed that soils had the potential for complete $\mathrm{N}$ removal during dry, summer conditions. During wet, winter conditions, however, the delivery of $\mathrm{N}$ in runoff may exceed the capacity of the soils to remove $\mathrm{N}$ via denitrification. Together, these results suggest that although the capacity of BRF soils to transform and remove $\mathrm{N}$ may be similar across seasonal conditions, the amount of rainfall may overwhelm this capacity, resulting in incomplete removal during extended rainfall (Sextone et al. 1985). Because the results of this study are a snapshot of conditions at the time of sampling, they may not capture the hysteretic nature of these processes (Groffman and Tiedje 1988; Stark and Firestone 1995). To get a clearer understanding of the efficacy of BRFs to remove $\mathrm{N}$ via denitrification processes, future research should consider actual $\mathrm{N}$ removal rates under field conditions during seasonal precipitation events. 


\subsection{Variability in soil properties}

$\mathrm{N}$ cycling processes were influenced by hydrologic properties of the surface soils. $\mathrm{N}$ cycling processes in soils with contrasting $\mathrm{K}_{\text {sat }}$ measurements (low and high) showed different seasonal sensitivities, with low $\mathrm{K}_{\text {sat }}$ soils showing no difference in rates across seasons, and high $\mathrm{K}_{\text {sat }}$ soils showing suppressed rates in summer (dry) and higher rates in winter (wet). The effect of $\mathrm{K}_{\text {sat }}$ on $\mathrm{N}$ cycling is likely indirect with $\mathrm{K}_{\text {sat }}$ moderating the oxygen dynamics of the soils. Diffusion processes are slower through a saturated soil relative to an unsaturated soil (Runkles 1956), and lower $\mathrm{K}_{\text {sat }}$ values represent BRF soils that are likely to drain runoff through the soil slower than higher values of $\mathrm{K}_{\text {sat, }}$ limiting oxygen diffusivity to soil microsites (Shackelford et al. 1991). This process may be significant for fostering greater $\mathrm{N}$ removal via denitrification (Groffman et al. 1988). In addition, positive relationships were observed between soil moisture content and SOM, suggesting that SOM may moderate soil moisture content and/or accumulate under wetter conditions due to decreased mineralization and decomposition (Bridgham et al. 1998; McPhillips and Walter 2015). Future research should further investigate the influence of $\mathrm{K}_{\text {sat }}$ on soil microbial processes that are sensitive to redox conditions to better understand how BRF site design can be maximized for pollutant removal and attenuation processes.

\subsection{Variability in management}

Though not an initial variable of interest in the design of these studies, management (or lack of management) emerged as an apparent physical difference across cities. However, when soil variables were observed through this lens, maintenance level was not found to have a specific or discernable impact on $\mathrm{N}$ cycling or soil bio- 
physiochemical properties. Some BRF sites in Baltimore, MD showed a lack of maintenance and upkeep, but those sites did not demonstrate differing rates of $\mathrm{N}$ cycling variables. However, nutrient cycling is but one ecosystem service that may be derived from BRFs. Other ecosystem services may be impacted by the frequency and degree of maintenance activities in these systems, such as aesthetic benefits or infiltration rates (MEA 2005; De Groot 2006). Unmaintained facilities had a considerable amount of litter, both organic detritus and anthropogenic trash, at the soil level and in the vegetation canopy. It is hypothesized that impermeable materials at the soil surface level may provide a barrier to runoff infiltration, thereby affecting the functionality of mitigating the volume of stormwater runoff. Additionally, urban areas that are not managed are considered "unpleasant and ugly," such as parks with dense vegetation and weeds (Lyytimäki et al. 2008). Littered, overgrown sites appeared to be derelict, and the location of the unkempt BRFs coincided with adjacent vacant lots or properties, and as a result, the aesthetic quality of BRFs is dramatically decreased in these conditions. Future research should evaluate the direct impact of organic detritus and anthropogenic litter on the infiltration capabilities of soils to better understand how specific maintenance strategies affect the functionality of GSI.

\subsection{Regional variability}

$\mathrm{N}$ cycling processes across distinct regions of the US did not show differences among cities with the exception of NYC, where potential denitrification rates were shown to be particularly high in this study and in other studies (Deeb et al. 2018). When all soil bio-physiochemical and $\mathrm{N}$ cycling variables were aggregated to create a profile of soil 
bio-physiochemical properties and $\mathrm{N}$ cycling parameters, BRFs across regions overlapped completely and did not show separation from one another. When compared to natural riparian soils within each region, BRF soils showed distinct and significant signatures. These results are among the first to suggest evidence of possible homogenizing effects of GSI systems across urban areas in the US (Groffman et al. 2014; Heffernan et al. 2014; Polsky et al. 2014; McPhillips and Walter 2015). Because BRFs and other GSI types are designed to satisfy NPDES stormwater management requirements (National Research Council 2009), cities are broadly implementing similar GSI designs, including similar vegetation, stormwater retention times, and nutrient inputs that may converge the ecologies and homogenize these types of systems across regions (McPhillips and Walter 2015). Because GSI is becoming an increasingly present feature in the urban landscape, ecological homogenization within these systems may have continental-scale effects on urban water and nutrient cycles (Groffman et al. 2014).

Evidence of ecological homogenization of BRF ecosystems was observed, as was a distinction between BRFs and natural riparian zones at the time of study. Because this dissertation is a snapshot of soil conditions at discrete points in time and $\mathrm{N}$ cycling processes under specific laboratory conditions, past conditions and future consequences are unknown. Thus, conclusions regarding whether BRFs demonstrate patterns of ecological convergence or divergence with analogous natural systems such as riparian zones cannot be made here. However, this study suggests that engineered stormwater systems may exhibit different ecological patterns and functions from theoretical natural analogues. To understand how ecosystem functions and services develop in BRFs 
through time, future research should consider how the unique properties that distinguish BRFs from natural analogues (engineered/constructed, isolated in the environment, experience more frequent and intense flooding events, receive supplies of organic and inorganic pollutants in urban runoff, designed and implemented in similar ways across regions) impact long-term ecosystem processes (Groffman et al. 2003; Palmer et al. 2014). This research can inform management and policy by increasing the understanding of the stability of urban ecosystem structure and functioning of engineered ecosystems under future conditions, and the impact of design and management decisions on the resilience of BRFs. 


\section{References}

Amati, M. and Taylor, L., 2010. From green belts to green infrastructure. Planning Practice \& Research, 25(2), pp.143-155.

Assessment, M.E., 2005. Ecosystems and human well-being: wetlands and water. World Resources Institute.

Bell, C.D., McMillan, S.K., Clinton, S.M. and Jefferson, A.J., 2016. Hydrologic response to stormwater control measures in urban watersheds. Journal of Hydrology, 541, pp.1488-1500.

Bernhardt, E.S., Band, L.E., Walsh, C.J. and Berke, P.E., 2008. Understanding, managing, and minimizing urban impacts on surface water nitrogen loading. Annals of the New York Academy of Sciences, 1134(1), pp.61-96.

Bettez, N.D. and Groffman, P.M., 2012. Denitrification potential in stormwater control structures and natural riparian zones in an urban landscape. Environmental science \& technology, 46(20), pp.10909-10917.

Bettez, N.D. and Groffman, P.M., 2013. Nitrogen deposition in and near an urban ecosystem. Environmental science \& technology, 47(11), pp.6047-6051.

Booth, D.B. and Henshaw, P.C., 2001. Rates of channel erosion in small urban streams. Water Science and application, 2, pp.17-38. 
Carter, T. and Fowler, L., 2008. Establishing green roof infrastructure through environmental policy instruments. Environmental management, 42(1), pp.151164.

Chen, X., Peltier, E., Sturm, B.S. and Young, C.B., 2013. Nitrogen removal and nitrifying and denitrifying bacteria quantification in a stormwater bioretention system. Water Research, 47(4), pp.1691-1700.

Chester K. Wentworth in a 1922 article in The Journal of Geology: "A Scale of Grade and Class Terms for Clastic Sediments".

Chocat, B., Krebs, P., Marsalek, J., Rauch, W. and Schilling, W., 2001. Urban drainage redefined: from stormwater removal to integrated management. Water Science and Technology, 43(5), pp.61-68.

CIRIA, 2000. Sustainable urban drainage systems - design manual for Scotland and Northern Ireland. Dundee, Scotland: CIRIA Report No. C521.

City of Portland National Pollutant Discharge Elimination System Municipal Separate Storm Sewer System (MS4) Discharge Permit. 2016. Retrieved from https://www.portlandoregon.gov/bes/article/507327 on 11 April 2019.

Cizek, A.R. and Hunt, W.F., 2013. Defining predevelopment hydrology to mimic predevelopment water quality in stormwater control measures (SCMs). Ecological engineering, 57, pp.40-45. 
Clément, J.C., Pinay, G. and Marmonier, P., 2002. Seasonal dynamics of denitrification along topohydrosequences in three different riparian wetlands. Journal of Environmental Quality, 31(3), pp.1025-1037.

Cole, C.A. and Shafer, D., 2002. Section 404 wetland mitigation and permit success criteria in Pennsylvania, USA, 1986-1999. Environmental Management, 30(4), pp.508-515.

Costanza, R., d'Arge, R., De Groot, R., Farber, S., Grasso, M., Hannon, B., Limburg, K., Naeem, S., O'neill, R.V., Paruelo, J. and Raskin, R.G., 1997. The value of the world's ecosystem services and natural capital. nature, 387(6630), p.253.

Davis, A.P., Shokouhian, M., Sharma, H. and Minami, C., 2001. Laboratory study of biological retention for urban stormwater management. Water Environment Research, 73(1), pp.5-14.

Davis, A.P., Traver, R.G., Hunt, W.F., Lee, R., Brown, R.A. and Olszewski, J.M., 2011. Hydrologic performance of bioretention storm-water control measures. Journal of Hydrologic Engineering, 17(5), pp.604-614.

De Groot, R., 2006. Function-analysis and valuation as a tool to assess land use conflicts in planning for sustainable, multi-functional landscapes. Landscape and urban planning, 75(3-4), pp.175-186.

De Groot, R.S., Wilson, M.A. and Boumans, R.M., 2002. A typology for the classification, description and valuation of ecosystem functions, goods and services. Ecological economics, 41(3), pp.393-408. 
Department of Environmental Resources, 1999. Low-impact development: an integrated design approach. Maryland, USA: Department of Environmental Resources, Prince George's County.

Dietz, M.E. and Clausen, J.C., 2008. Stormwater runoff and export changes with development in a traditional and low impact subdivision. Journal of Environmental Management, 87(4), pp.560-566.

Dietz, M.E., 2007. Low impact development practices: A review of current research and recommendations for future directions. Water, air, and soil pollution, 186(1-4), pp.351-363.

Drury, C.F., Voroney, R.P. and Beauchamp, E.G., 1991. Availability of NH4+ ${ }^{+} \mathrm{N}$ to microorganisms and the soil internal N cycle. Soil Biology and Biochemistry, 23(2), pp.165-169.

Fletcher, T., Zinger, Y., Deletic, A. and Bratières, K., 2007. Treatment efficiency of biofilters; results of a large-scale column study. Rainwater and Urban Design 2007 , p.266.

Fletcher, T.D., Shuster, W., Hunt, W.F., Ashley, R., Butler, D., Arthur, S., Trowsdale, S., Barraud, S., Semadeni-Davies, A., Bertrand-Krajewski, J.L. and Mikkelsen, P.S., 2015. SUDS, LID, BMPs, WSUD and more-The evolution and application of terminology surrounding urban drainage. Urban Water Journal, 12(7), pp.525542. 
Galloway, J.N., Schlesinger, W.H., Levy, H., Michaels, A. and Schnoor, J.L., 1995. Nitrogen fixation: Anthropogenic enhancement-environmental response. Global biogeochemical cycles, 9(2), pp.235-252.

Grimm, N.B., Faeth, S.H., Golubiewski, N.E., Redman, C.L., Wu, J., Bai, X. and Briggs, J.M., 2008. Global change and the ecology of cities. science, 319(5864), pp.756760.

Grimm, N.B., Sheibley, R.W., Crenshaw, C.L., Dahm, C.N., Roach, W.J. and Zeglin, L.H., 2005. $\mathrm{N}$ retention and transformation in urban streams. Journal of the North American Benthological Society, 24(3), pp.626-642.

Groffman, P.M., Bain, D.J., Band, L.E., Belt, K.T., Brush, G.S., Grove, J.M., Pouyat, R.V., Yesilonis, I.C. and Zipperer, W.C., 2003. Down by the riverside: urban riparian ecology. Frontiers in Ecology and the Environment, 1(6), pp.315-321.

Groffman, P.M., Tiedje, J.M., Robertson, G.P. and Christensen, S., 1988. Denitrification at different temporal and geographical scales: proximal and distal controls. Advances in nitrogen cycling in agricultural ecosystems, pp.174-192.

Hamilton, S.K., Tank, J.L., Raikow, D.F., Wollheim, W.M., Peterson, B.J. and Webster, J.R., 2001. Nitrogen uptake and transformation in a midwestern US stream: a stable isotope enrichment study. Biogeochemistry, 54(3), pp.297-340.

Hamilton, S.K., Tank, J.L., Raikow, D.F., Wollheim, W.M., Peterson, B.J. and Webster, J.R., 2001. Nitrogen uptake and transformation in a midwestern US stream: a stable isotope enrichment study. Biogeochemistry, 54(3), pp.297-340. 
Harms, T.K. and Grimm, N.B., 2008. Hot spots and hot moments of carbon and nitrogen dynamics in a semiarid riparian zone. Journal of Geophysical Research: Biogeosciences, 113(G1).

Hatt, B.E., Fletcher, T.D. and Deletic, A., 2009. Hydrologic and pollutant removal performance of stormwater biofiltration systems at the field scale. Journal of Hydrology, 365(3-4), pp.310-321.

Henderson, C., Greenway, M. and Phillips, I., 2007. Removal of dissolved nitrogen, phosphorus and carbon from stormwater by biofiltration mesocosms. Water Science and Technology, 55(4), pp.183-191.

Hill, A. R. Nitrate removal in stream riparian zones. J. Environ. Qual. 1996, 25 (4), $743-755$.

Hollis, G.E., 1975. The effect of urbanization on floods of different recurrence interval. Water Resources Research, 11(3), pp.431-435.

Howarth, R.W., Billen, G., Swaney, D., Townsend, A., Jaworski, N., Lajtha, K., Downing, J.A., Elmgren, R., Caraco, N., Jordan, T. and Berendse, F., 1996. Regional nitrogen budgets and riverine $\mathrm{N} \& \mathrm{P}$ fluxes for the drainages to the North Atlantic Ocean: Natural and human influences. In Nitrogen cycling in the North Atlantic Ocean and its watersheds (pp. 75-139). Springer, Dordrecht.

Hunt, W.F., Davis, A.P. and Traver, R.G., 2012. Meeting hydrologic and water quality goals through targeted bioretention design. Journal of Environmental Engineering, 138(6), pp.698-707. 
Hunt, W.F., Jarrett, A.R., Smith, J.T. and Sharkey, L.J., 2006. Evaluating bioretention hydrology and nutrient removal at three field sites in North Carolina. Journal of Irrigation and Drainage Engineering, 132(6), pp.600-608.

Jetten, M.S., 2008. The microbial nitrogen cycle. Environmental microbiology, 10(11), pp.2903-2909.

Kambites, C. and Owen, S., 2006. Renewed prospects for green infrastructure planning in the UK. Planning, Practice \& Research, 21(4), pp.483-496.

Kaushal, S.S. and Belt, K.T., 2012. The urban watershed continuum: evolving spatial and temporal dimensions. Urban Ecosystems, 15(2), pp.409-435.

Kaye, J.P., Groffman, P.M., Grimm, N.B., Baker, L.A. and Pouyat, R.V., 2006. A distinct urban biogeochemistry?. Trends in Ecology \& Evolution, 21(4), pp.192-199.

Khalil, M.A.K. and Rasmussen, R.A., 1992. The global sources of nitrous oxide. Journal of geophysical research: atmospheres, 97(D13), pp.14651-14660.

Kim, H., Seagren, E.A. and Davis, A.P., 2003. Engineered bioretention for removal of nitrate from stormwater runoff. Water Environment Research, 75(4), pp.355-367.

Knowles, R., 1982. Denitrification. Microbiological reviews, 46(1), p.43.

Leopold, L.B., 1968. Hydrology for urban land planning: A guidebook on the hydrologic effects of urban land use (Vol. 554). US Department of the Interior, Geological Survey. 
Lucas, W.C. and Greenway, M., 2011. Hydraulic response and nitrogen retention in bioretention mesocosms with regulated outlets: Part I-Hydraulic Response. Water Environment Research, 83(8), pp.692-702.

Lyytimäki, J., Petersen, L.K., Normander, B. and Bezák, P., 2008. Nature as a nuisance? Ecosystem services and disservices to urban lifestyle. Environmental Sciences, 5(3), pp.161-172.

Mayer, P. M.; Reynolds, S. K.; McCutchen, M. D.; Canfield, T.J. Meta-analysis of nitrogen removal in riparian buffers. J. Environ. Qual. 2007, 36 (4), 1172-1180.

McDonnell, M.J. and Pickett, S.T., 1990. Ecosystem structure and function along urbanrural gradients: an unexploited opportunity for ecology. Ecology, 71(4), pp.12321237.

McGill, B.M., Sutton-Grier, A.E. and Wright, J.P., 2010. Plant trait diversity buffers variability in denitrification potential over changes in season and soil conditions. PLoS One, 5(7), p.e11618.

McPhillips, L. and Walter, M.T., 2015. Hydrologic conditions drive denitrification and greenhouse gas emissions in stormwater detention basins. Ecological Engineering, 85, pp.67-75.

McPhillips, L.E. and Matsler, A.M., 2018. Temporal evolution of green stormwater infrastructure strategies in three US cities. Frontiers in Built Environment, 4, p.26. 
Millennium Ecosystem Assessment, 2005. Ecosystems and human well-being (Vol. 5). Washington, DC: Island press.

Moore, T.L. and Hunt, W.F., 2012. Ecosystem service provision by stormwater wetlands and ponds-A means for evaluation. Water research, 46(20), pp.6811-6823.

Morse, N.R., McPhillips, L.E., Shapleigh, J.P. and Walter, M.T., 2017. The role of denitrification in stormwater detention basin treatment of nitrogen. Environmental science \& technology, 51(14), pp.7928-7935.

National Research Council, 2009. Urban stormwater management in the United States. National Academies Press.

Ni, W.Z. and Zhu, Z.L., 2004. Evidence of N 2 O emission and gaseous nitrogen losses through nitrification-denitrification induced by rice plants (Oryza sativa L.). Biology and fertility of soils, 40(3), pp.211-214.

Norton, R.A., Harrison, J.A., Keller, C.K. and Moffett, K.B., 2017. Effects of storm size and frequency on nitrogen retention, denitrification, and $\mathrm{N}_{2} \mathrm{O}$ production in bioretention swale mesocosms. Biogeochemistry, 134(3), pp.353-370.

O'Connor, B.L., Hondzo, M., Dobraca, D., LaPara, T.M., Finlay, J.C. and Brezonik, P.L., 2006. Quantity-activity relationship of denitrifying bacteria and environmental scaling in streams of a forested watershed. Journal of Geophysical Research: Biogeosciences, 111(G4). 
Palmer, M.A., Filoso, S. and Fanelli, R.M., 2014. From ecosystems to ecosystem services: Stream restoration as ecological engineering. Ecological Engineering, 65, pp.62-70.

Pataki, D.E., Carreiro, M.M., Cherrier, J., Grulke, N.E., Jennings, V., Pincetl, S., Pouyat, R.V., Whitlow, T.H. and Zipperer, W.C., 2011. Coupling biogeochemical cycles in urban environments: ecosystem services, green solutions, and misconceptions. Frontiers in Ecology and the Environment, 9(1), pp.27-36.

Payne, E.G., Fletcher, T.D., Russell, D.G., Grace, M.R., Cavagnaro, T.R., Evrard, V., Deletic, A., Hatt, B.E. and Cook, P.L., 2014. Temporary storage or permanent removal? The division of nitrogen between biotic assimilation and denitrification in stormwater biofiltration systems. PloS one, 9(3), p.e90890.

Pinay, G., Roques, L. and Fabre, A., 1993. Spatial and temporal patterns of denitrification in a riparian forest. Journal of Applied Ecology, pp.581-591.

Pitt, R., Maestre, A. and Morquecho, R., 2004, February. The national stormwater quality database (NSQD, version 1.1). In 1st Annual Stormwater Management Research Symposium Proceedings (pp. 13-51).

Polsky, C., Grove, J.M., Knudson, C., Groffman, P.M., Bettez, N., Cavender-Bares, J., Hall, S.J., Heffernan, J.B., Hobbie, S.E., Larson, K.L. and Morse, J.L., 2014. Assessing the homogenization of urban land management with an application to US residential lawn care. Proceedings of the National Academy of Sciences, 111(12), pp.4432-4437. 
Portland Stormwater Management Manual 2016.

https://www.portlandoregon.gov/bes/71127.

Rabalais, N.N., Turner, R.E. and Wiseman Jr, W.J., 2002. Gulf of Mexico hypoxia, aka “The dead zone". Annual Review of ecology and Systematics, 33(1), pp.235-263.

Rawls, W.J., Brakensiek, D.L. and Saxtonn, K.E., 1982. Estimation of soil water properties. Transactions of the ASAE, 25(5), pp.1316-1320.Rawls, W.J., Pachepsky, Y.A., Ritchie, J.C., Sobecki, T.M. and Bloodworth, H., 2003. Effect of soil organic carbon on soil water retention. Geoderma, 116(1-2), pp.61-76.

Reddy, K.R. and D'angelo, E.M., 1997. Biogeochemical indicators to evaluate pollutant removal efficiency in constructed wetlands. Water Science and Technology, 35(5), pp.1-10.

Robertson, G.P. and Groffman, P.M., 2007. Nitrogen transformations. In Soil microbiology, ecology and biochemistry (pp. 341-364). Academic Press.

Robertson, G.P. and Groffman, P.M., 2015. Chapter 14-Nitrogen Transformations. Soil Microbiology Ecology and Biochemistry; Elsevier Inc.: Amsterdam, The Netherlands, pp.421-446.

Seto, K.C., Fragkias, M., Güneralp, B. and Reilly, M.K., 2011. A meta-analysis of global urban land expansion. PloS one, 6(8), p.e23777. 
Sexstone, A.J., Parkin, T.B. and Tiedje, J.M., 1985. Temporal Response of Soil Denitrification Rates to Rainfall and Irrigation 1. Soil Science Society of America Journal, 49(1), pp.99-103.

Stanley, D.W., 1996. Pollutant removal by a stormwater dry detention pond. Water Environment Research, 68(6), pp.1076-1083.

Tao, W., Bays, J., Meyer, D., Smardon, R. and Levy, Z., 2014. Constructed wetlands for treatment of combined sewer overflow in the US: A review of design challenges and application status. Water, 6(11), pp.3362-3385.

Tzoulas, K., Korpela, K., Venn, S., Yli-Pelkonen, V., Kaźmierczak, A., Niemela, J. and James, P., 2007. Promoting ecosystem and human health in urban areas using Green Infrastructure: A literature review. Landscape and urban planning, 81(3), pp.167-178.

Vidon, P., Allan, C., Burns, D., Duval, T.P., Gurwick, N., Inamdar, S., Lowrance, R., Okay, J., Scott, D. and Sebestyen, S., 2010. Hot spots and hot moments in riparian zones: potential for improved water quality management1. JAWRA Journal of the American Water Resources Association, 46(2), pp.278-298.

Vitousek, P.M., 1994. Beyond global warming: ecology and global change. Ecology, 75(7), pp.1861-1876.

Vitousek, P.M., Aber, J.D., Howarth, R.W., Likens, G.E., Matson, P.A., Schindler, D.W., Schlesinger, W.H. and Tilman, D.G., 1997. Human alteration of the global 
nitrogen cycle: sources and consequences. Ecological applications, 7(3), pp.737750.

Waller, L.J., Evanylo, G.K., Krometis, L.A.H., Strickland, M.S., Wynn-Thompson, T. and Badgley, B.D., 2018. Engineered and Environmental Controls of Microbial Denitrification in Established Bioretention Cells. Environmental science \& technology, 52(9), pp.5358-5366.

Walsh, C.J., Fletcher, T.D. and Ladson, A.R., 2005. Stream restoration in urban catchments through redesigning stormwater systems: looking to the catchment to save the stream. Journal of the North American Benthological Society, 24(3), pp.690-705.

Wong, T.H., 2006. Water sensitive urban design-the journey thus far. Australasian Journal of Water Resources, 10(3), pp.213-222.

Wu, J.J., 2008. Making the case for landscape ecology an effective approach to urban sustainability. Landscape journal, 27(1), pp.41-50. 


\section{Appendix A: BRF Study Sites}

Table A1. BRF sites studied in Portland, OR in 2015 (Chapter 2).

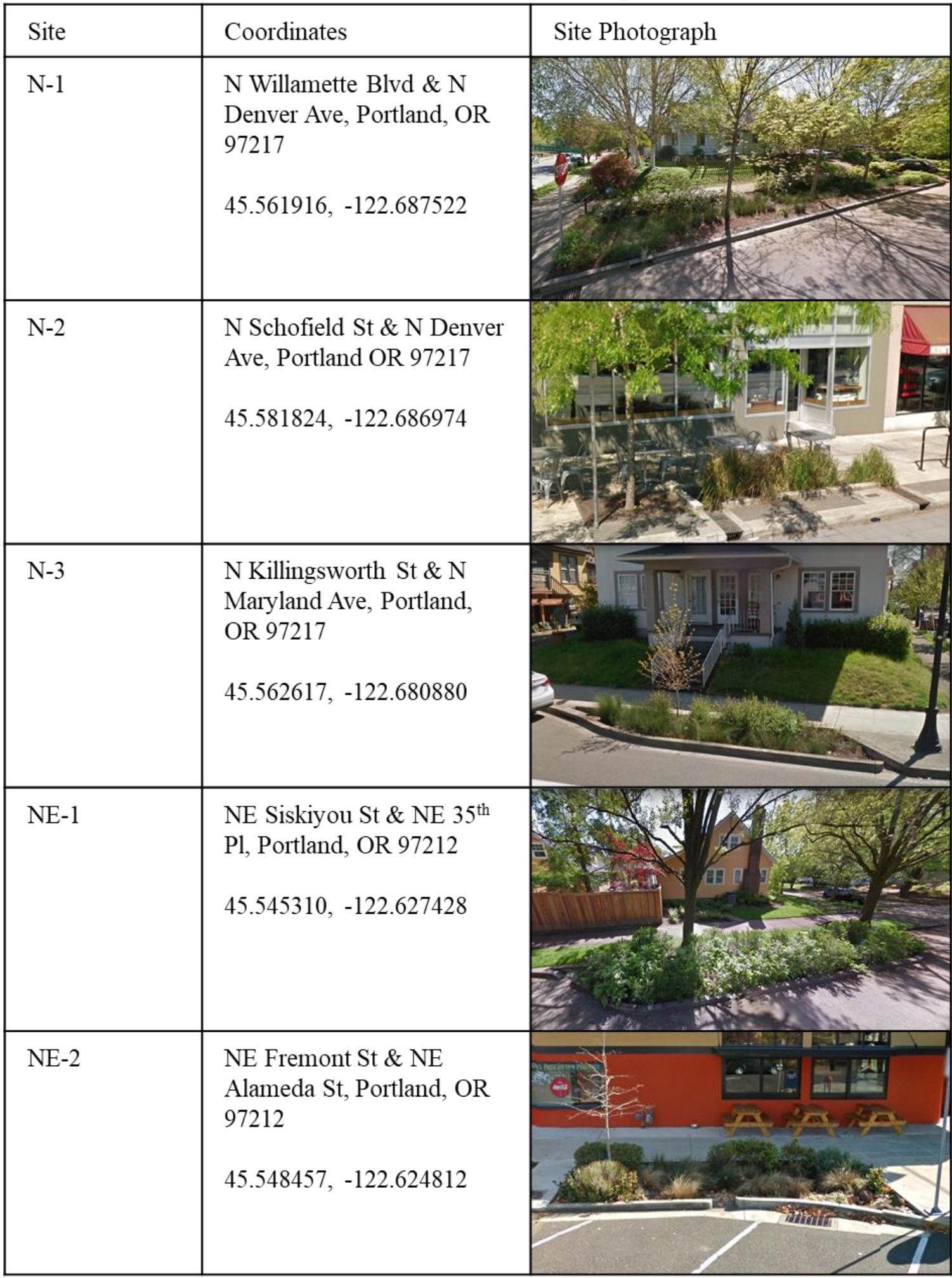


Table A2. BRF sites studied in Portland, OR in 2015 (Chapter 2).

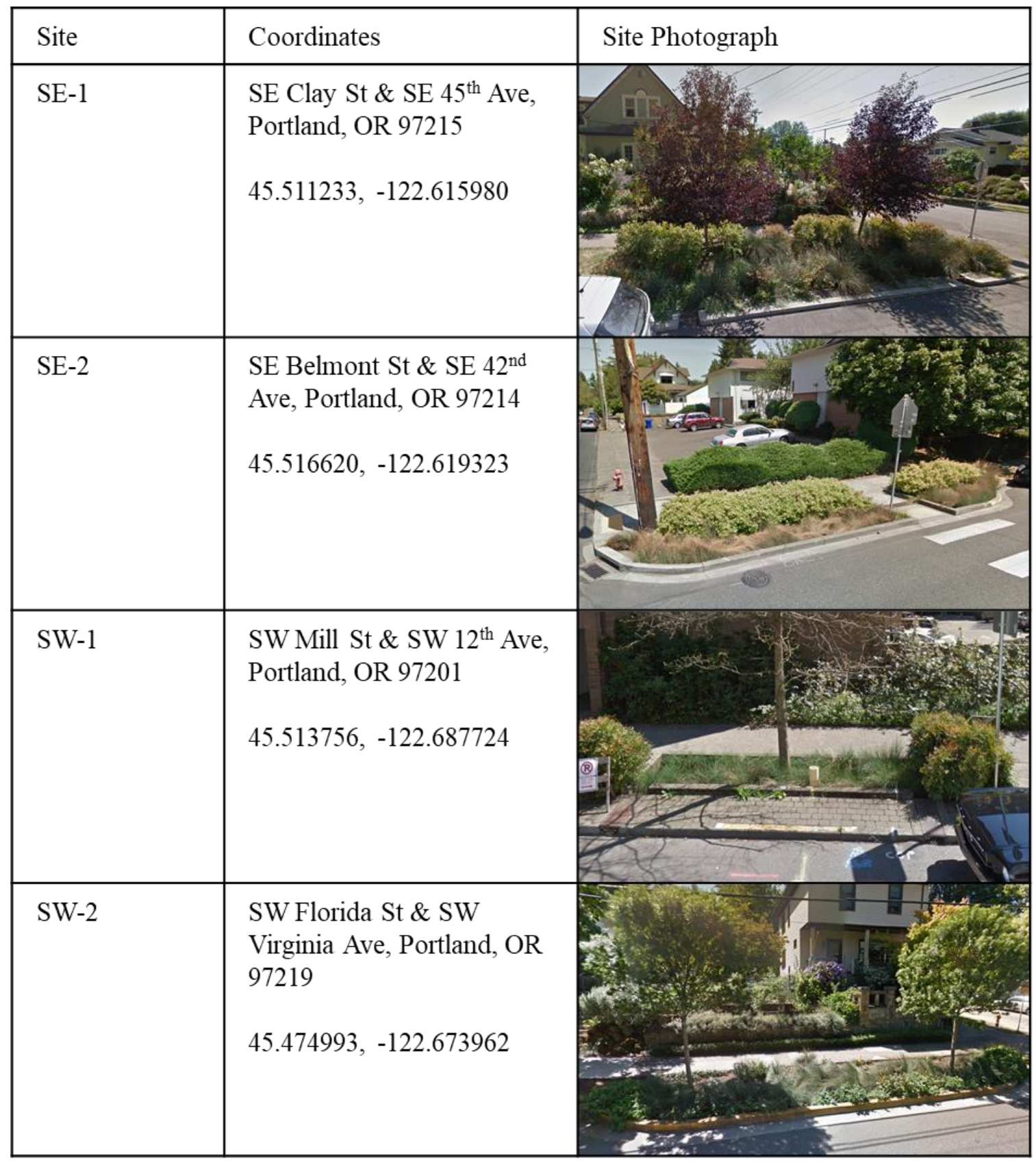


Table A3. BRF sites studied in Portland, OR in 2015 (Chapter 3).

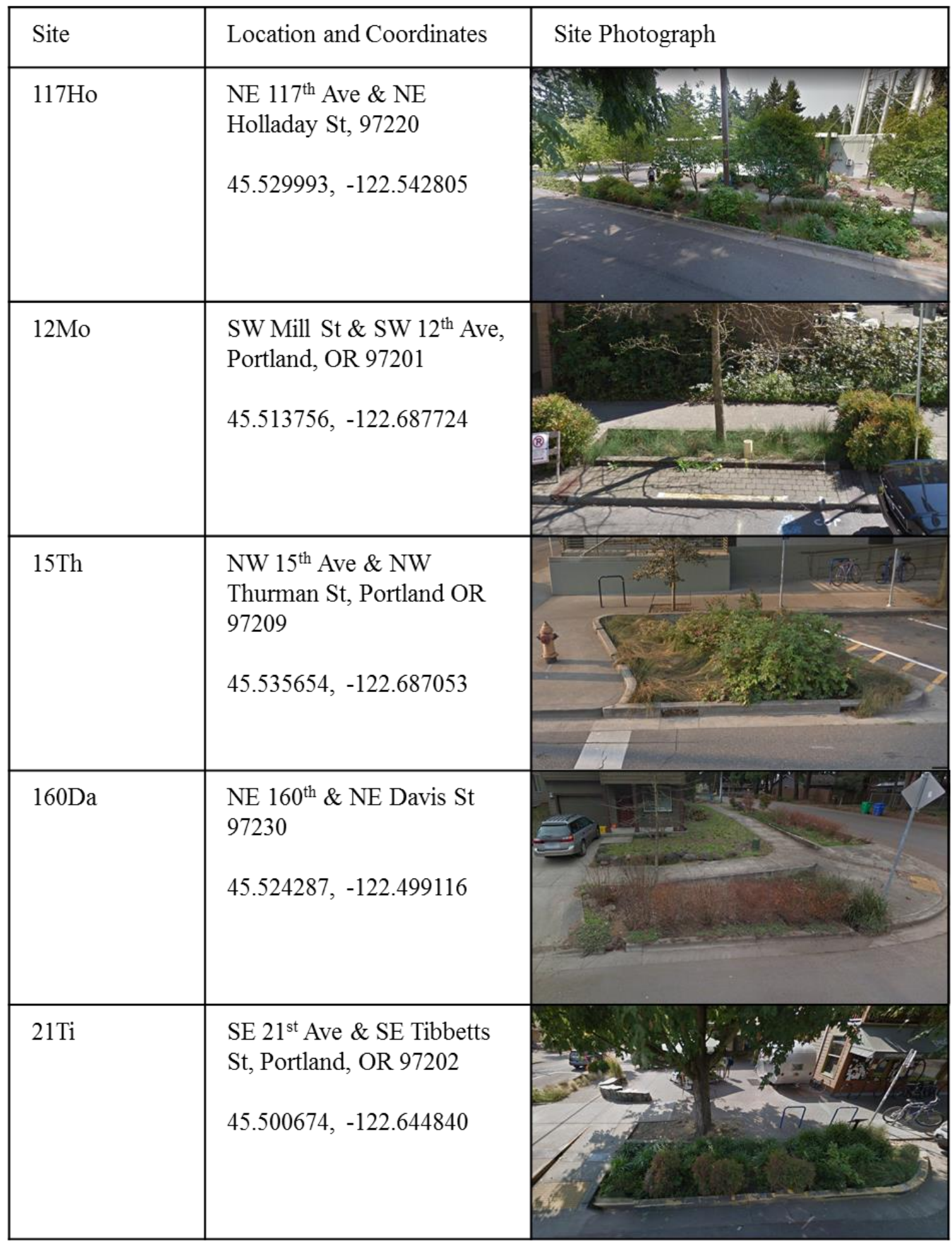


Table A4. BRF sites studied in Portland, OR in 2016 (Chapter 3).

\begin{tabular}{|c|c|c|}
\hline Site & Location and Coordinates & Site Photograph \\
\hline $35 \mathrm{Si}$ & $\begin{array}{l}\text { NE Siskiyou St \& NE } 35^{\text {th }} \\
\text { Pl, Portland, OR } 97212 \\
45.545310,-122.627428\end{array}$ & \\
\hline $35 \mathrm{Ye}$ & $\begin{array}{l}\text { NW Yeon Ave \& NW } 35^{\text {th }} \\
\text { Ave, Portland, OR } 97210 \\
45.548327,-122.719009\end{array}$ & \\
\hline $42 \mathrm{Be}$ & $\begin{array}{l}\text { SE Belmont St \& SE } 42^{\text {nd }} \\
\text { Ave, Portland, OR } 97214 \\
45.516620,-122.619323\end{array}$ & \\
\hline $45 \mathrm{Cl}$ & $\begin{array}{l}\text { SE Clay St \& SE } 45^{\text {th }} \text { Ave, } \\
\text { Portland, OR } 97215 \\
45.511233,-122.615980\end{array}$ & \\
\hline $7 \mathrm{Co}$ & $\begin{array}{l}\text { NE Couch St and NE } 7^{\text {th }} \\
\text { Ave, Portland, OR } 97232 \\
45.523593,-122.658488\end{array}$ & \\
\hline
\end{tabular}


Table A5. BRF sites studied in Portland, OR in 2016 (Chapter 3).

\begin{tabular}{|c|c|c|}
\hline Site & Location and Coordinates & Site Photograph \\
\hline $\mathrm{AlPr}$ & $\begin{array}{l}\text { N Albina Ave \& N Prescott } \\
\text { St, Portland, OR } 97217 \\
45.555495,-122.675077\end{array}$ & \\
\hline DeWi & $\begin{array}{l}\text { N Willamette Blvd \& N } \\
\text { Denver Ave, Portland, OR } \\
97217 \\
45.561916,-122.687522\end{array}$ & \\
\hline FrAl & $\begin{array}{l}\text { NE Fremont St \& NE } \\
\text { Alameda St, Portland, OR } \\
97212 \\
45.548457,-122.624812\end{array}$ & \\
\hline KiMa & $\begin{array}{l}\text { N Killingsworth St \& N } \\
\text { Maryland Ave, Portland, } \\
\text { OR } 97217 \\
45.562617,-122.680880\end{array}$ & \\
\hline WiSu & $\begin{array}{l}\text { N Williams Ave \& N } \\
\text { Sumner St, Portland, OR } \\
97217 \\
45.560463,-122.666721\end{array}$ & \\
\hline
\end{tabular}


Table A6. BRF sites studied in Baltimore, MD in 2016 (Chapter 3).

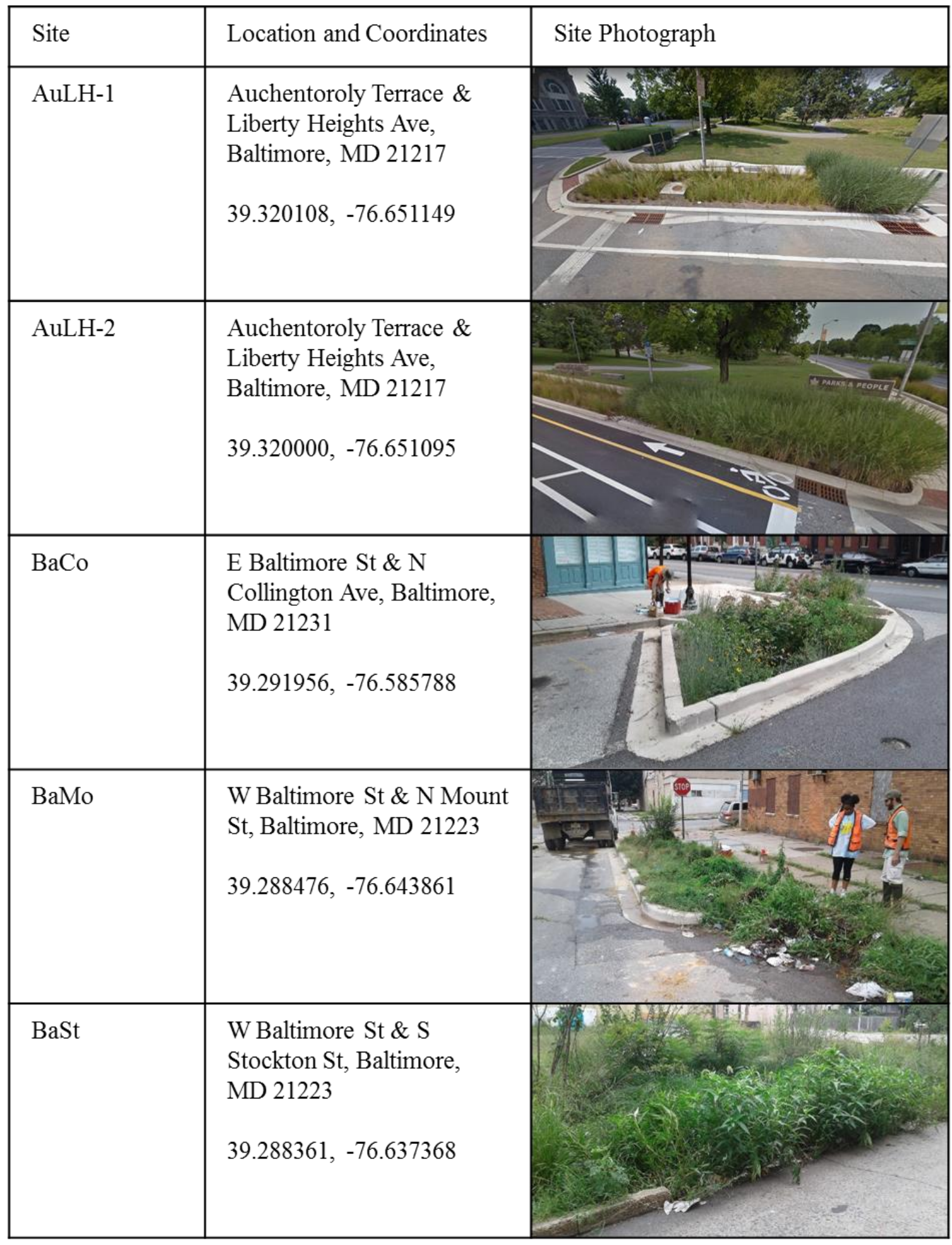


Table A7. BRF sites studied in Baltimore, MD in 2016 (Chapter 3).

\begin{tabular}{|l|l|l|}
\hline Site & Location and Coordinates & Site Photograph \\
\hline BrLa & $\begin{array}{l}\text { Bruce St \& Laurens St, } \\
\text { Baltimore, MD 21217 } \\
39.303300,-76.645398\end{array}$ \\
\hline FaCa & $\begin{array}{l}\text { E Fairmount Ave \& N } \\
\text { Castle St, Baltimore, MD } \\
21231\end{array}$ \\
$39.292947,-76.587946$ & \\
\hline FaCh & $\begin{array}{l}\text { E Fairmount Ave and S } \\
\text { Chester St, Baltimore, MD } \\
21231 \\
39.292938,-76.587565\end{array}$ \\
\hline FaMo-1 & $\begin{array}{l}\text { St, Baltimore, MD 21223 } \\
39.289738,-76.643924\end{array}$ \\
\hline $\begin{array}{l}\text { W FaFu } \\
\text { Ave, Baltimore, MD 21223 } \\
39.289483,-76.645513\end{array}$ \\
\hline
\end{tabular}


Table A8. BRF sites studied in Baltimore, MD in 2016 (Chapter 3).

\begin{tabular}{|l|l|l|}
\hline Site & Location and Coordinates & Site Photograph \\
\hline FaMo-2 & $\begin{array}{l}\text { W Fayette St \& N Mount } \\
\text { St, Baltimore, MD 21223 } \\
39.289617,-76.644175\end{array}$ \\
\hline FaPo-1 & $\begin{array}{l}\text { E Fayette St \& N Potomac } \\
\text { St, Baltimore, MD 21224 } \\
39.294855,-76.574890\end{array}$ \\
\hline FaPo-2 & $\begin{array}{l}\text { E Fayette St \& N Potomac } \\
\text { St, Baltimore, MD 21224 } \\
39.294616,-76.574884\end{array}$ \\
\hline ReSw & $\begin{array}{l}\text { Reisterstown Rd \& } \\
\text { Auchentoroloy Terrace, } \\
\text { Baltimore, MD 21217 } \\
39.321595,-76.654551\end{array}$ \\
\hline MoLe & $\begin{array}{l}\text { N Mount St \& W } \\
\text { Lexington St, Baltimore, } \\
39.290896,-76.643988\end{array}$ & \\
\hline 5
\end{tabular}


Table A9. BRF sites studied in Baltimore, MD in 2017 (Chapter 4).

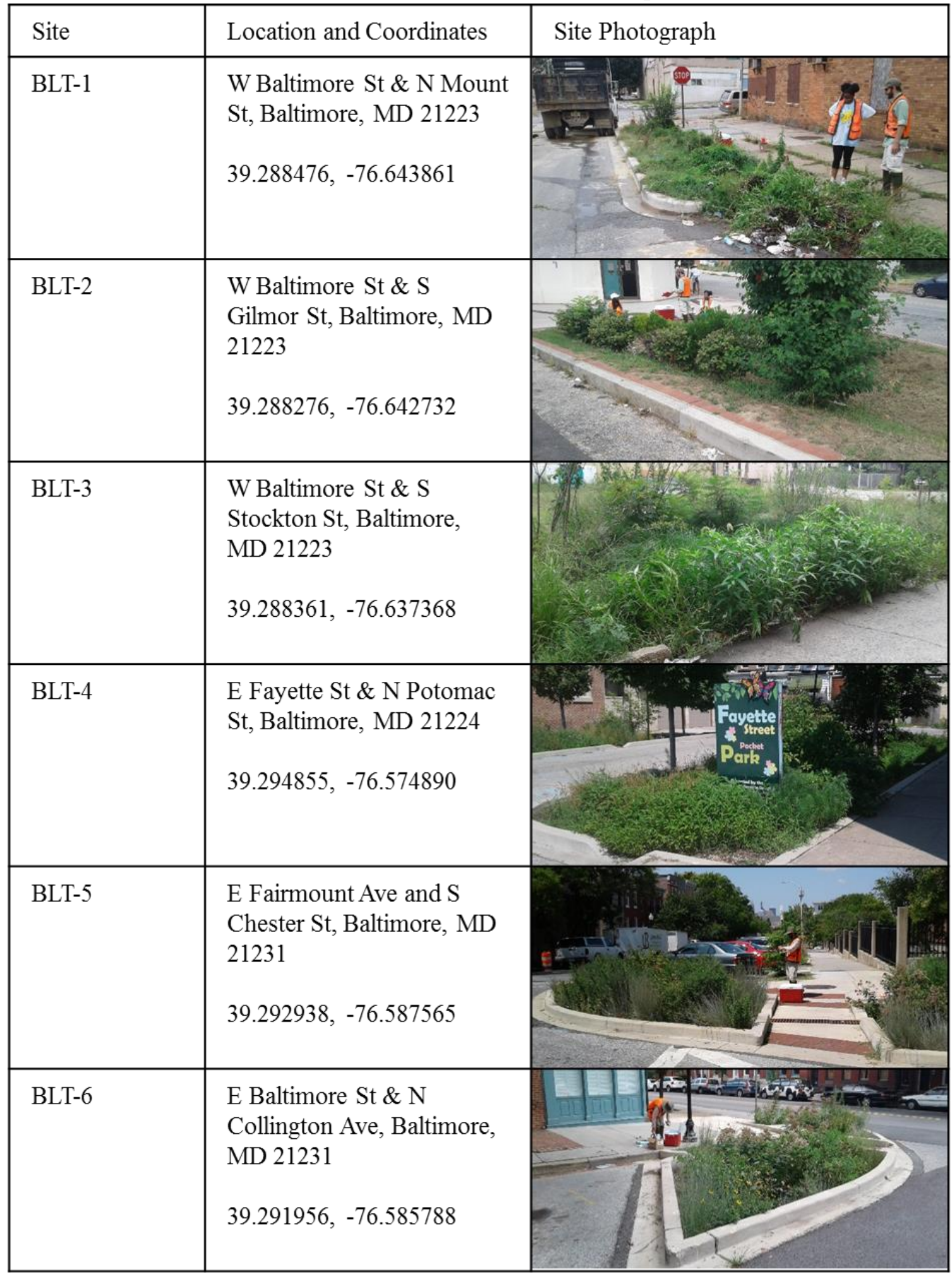


Table A10. BRF sites studied in Charlotte, NC in 2017 (Chapter 4).

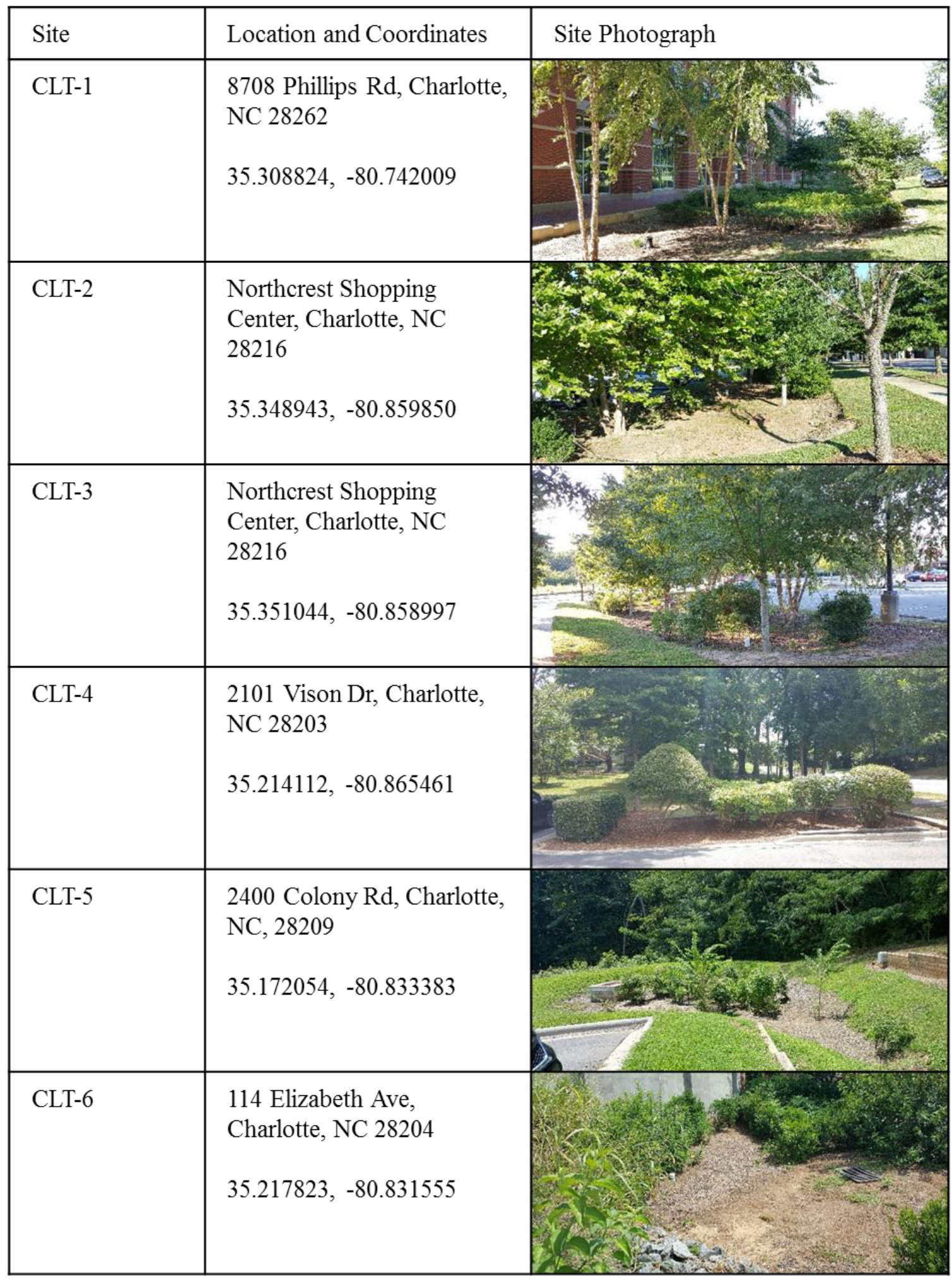


Table A11. BRF sites studied in New York, NY in 2017 (Chapter 4). Photos were taken from Google Street View, and views of NYC-4, NYC-5, and NYC-6 were obstructed by vehicles (size and vegetation are visible).

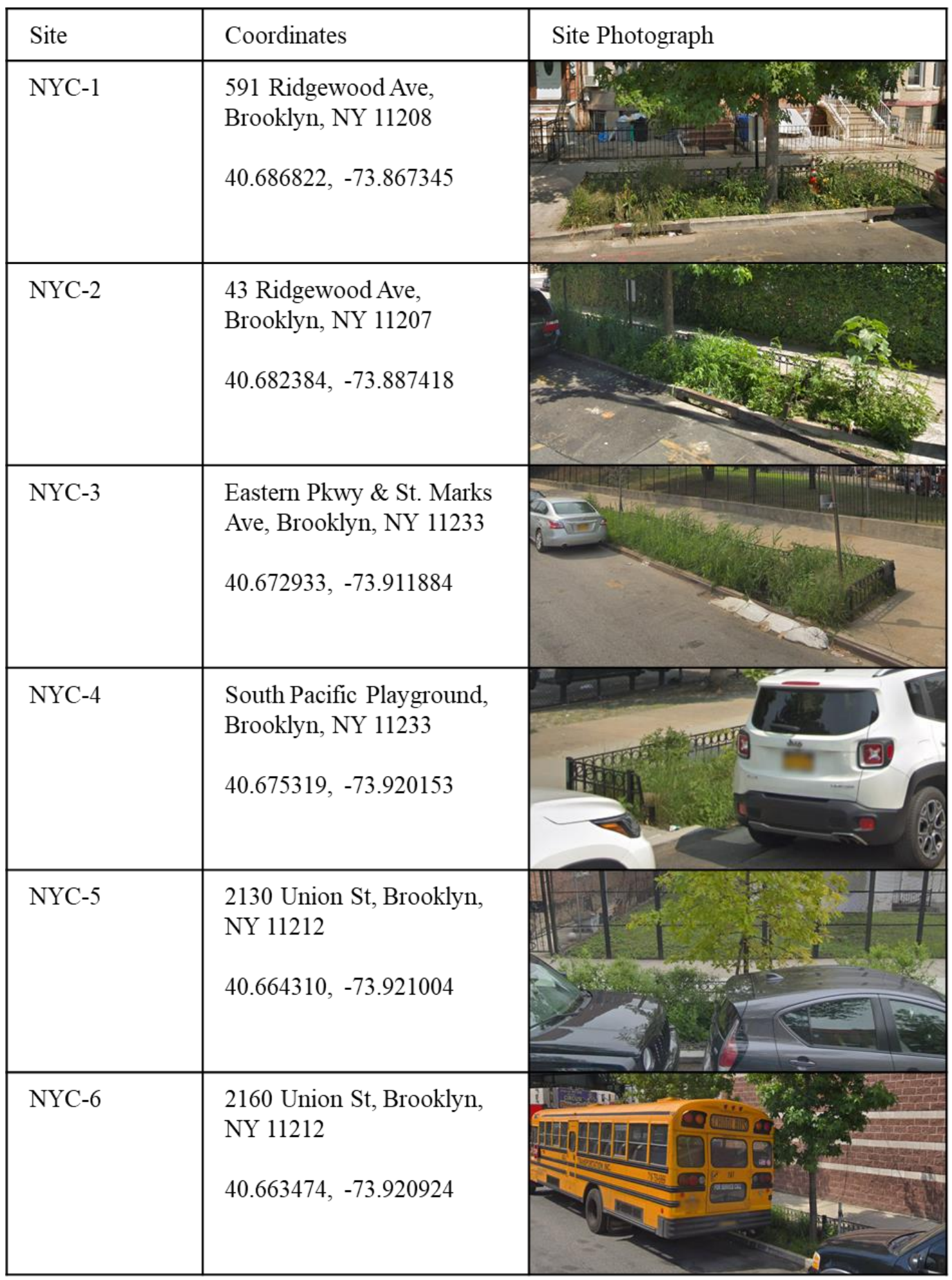


Table A12. BRF sites studied in Portland, OR in 2017 (Chapter 4).

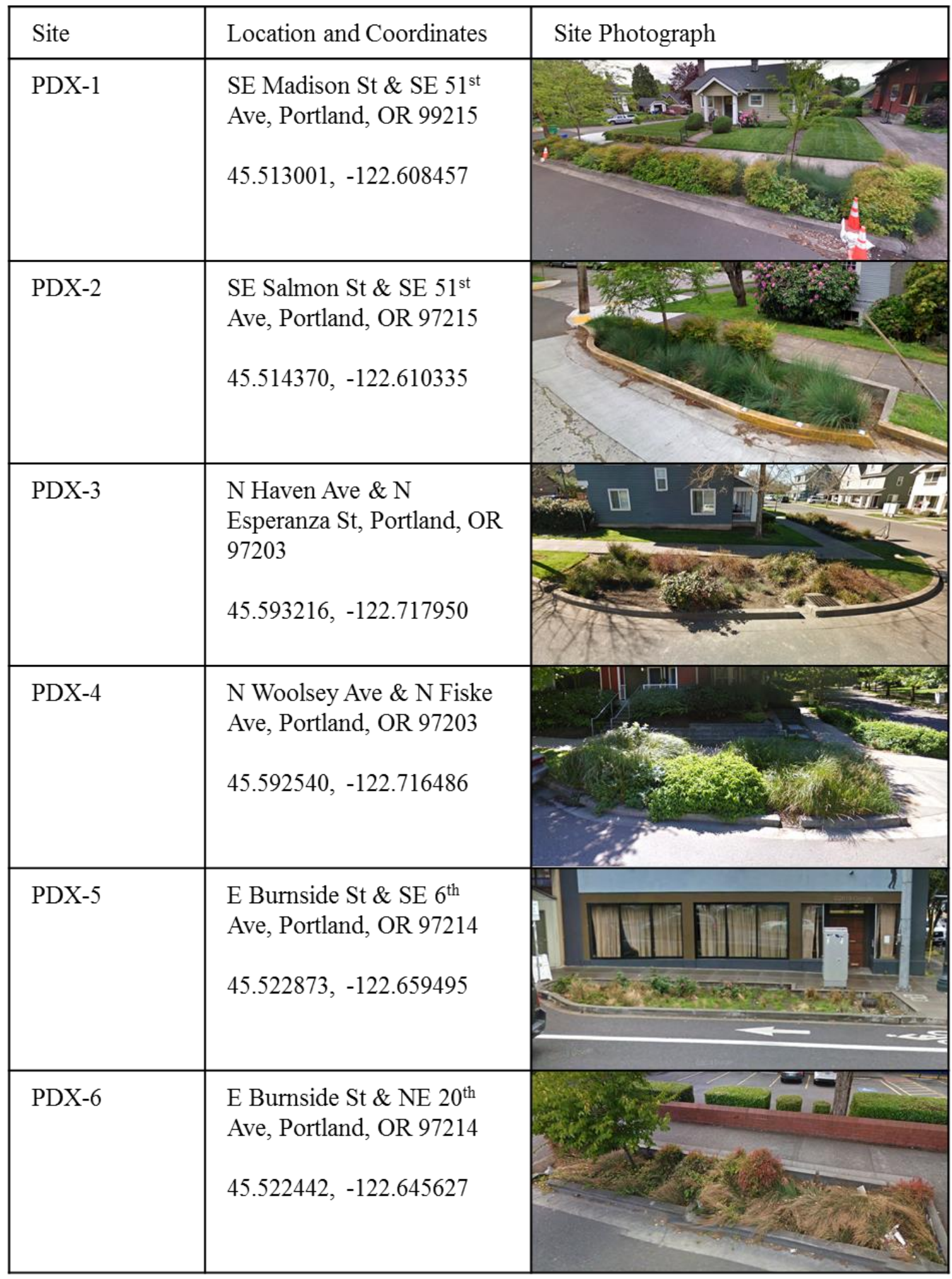


Table A13. BRF sites studied in Phoenix, AZ in 2017 (Chapter 4).

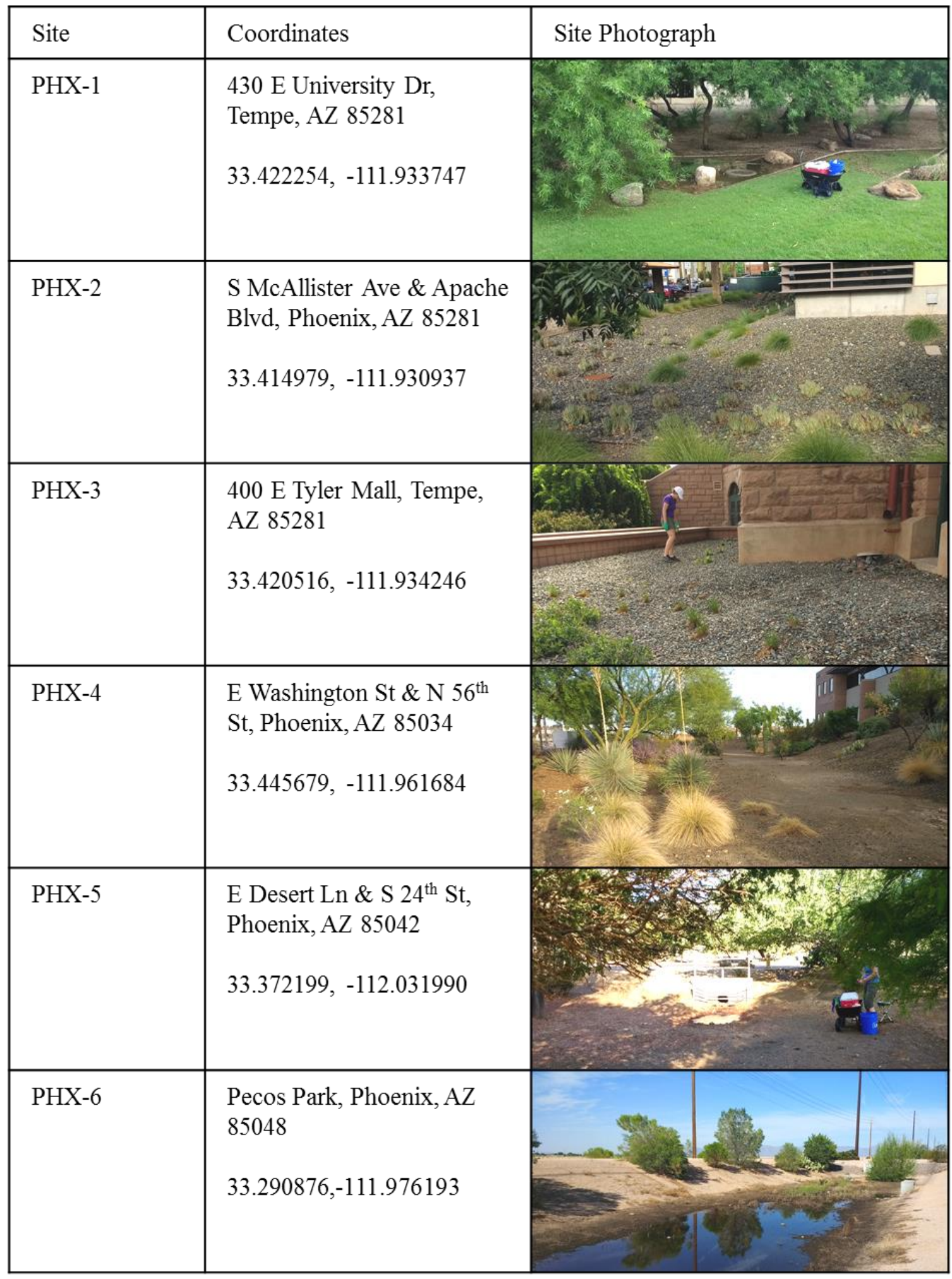




\section{Appendix B: Additional Tables}

Table B.1. Multiple linear regression model comparisons.

\begin{tabular}{|c|c|c|c|c|c|c|c|c|c|}
\hline Process & $\begin{array}{c}\text { Variables } \\
\text { Tested }\end{array}$ & City & Season & $\begin{array}{c}\text { Generalized } \\
\text { Selected } \\
\text { Model } \\
\end{array}$ & $\mathrm{R}^{2} \mathrm{adj}$ & $p$ & AIC & $\begin{array}{l}\text { Rejected } \\
\text { Variables }\end{array}$ & Significance \\
\hline \multirow[t]{4}{*}{ DEA } & \multirow{4}{*}{$\begin{array}{c}\mathrm{SM}, \\
\mathrm{SOM} \\
\mathrm{MBC}, \\
\mathrm{MBN}, \\
\mathrm{NO}_{3}-\mathrm{N}, \\
\mathrm{pH}, \\
\% \text { fines }\end{array}$} & \multirow[t]{2}{*}{ Baltimore } & Summer & $\begin{array}{c}\mathrm{SOM}+\mathrm{SM} \\
+ \\
\mathrm{NO}_{3}-\mathrm{N}\end{array}$ & 0.74 & 0.00045 & 52.01 & $\begin{array}{c}\mathrm{MBC}, \mathrm{MBN}, \\
\mathrm{pH}, \% \text { fines }\end{array}$ & $* * *$ \\
\hline & & & Winter & $\mathrm{SM}$ & 0.56 & 0.00076 & 52.57 & $\begin{array}{l}\mathrm{SOM}, \mathrm{MBC} \\
\mathrm{MBN}, \mathrm{NO}_{3-} \\
\mathrm{N}, \mathrm{pH}, \% \\
\text { fines }\end{array}$ & $* * *$ \\
\hline & & \multirow[t]{2}{*}{ Portland } & Summer & $\begin{array}{c}\mathrm{MBN}+\mathrm{pH} \\
+\mathrm{MBC}+ \\
\mathrm{NO}_{3}-\mathrm{N}\end{array}$ & 0.76 & 0.00074 & 45.05 & $\begin{array}{l}\text { SM, SOM, \% } \\
\text { fines }\end{array}$ & $* * *$ \\
\hline & & & Winter & $\begin{array}{c}\mathrm{MBC}+\mathrm{SM} \\
+\mathrm{SOM}\end{array}$ & 0.63 & 0.0027 & -40 & $\begin{array}{c}\mathrm{MBN}, \mathrm{NO}_{3}^{-} \\
\mathrm{N}, \mathrm{pH}, \% \\
\text { fines }\end{array}$ & $* *$ \\
\hline \multirow[t]{4}{*}{ Min } & \multirow{4}{*}{$\begin{array}{c}\text { SM, } \\
\text { SOM, } \\
\text { Microbial } \\
\text { C:N, } \\
\text { \% fines }\end{array}$} & \multirow[t]{2}{*}{ Baltimore } & Summer & SM & 0.10 & 0.129 & 13.39 & $\begin{array}{c}\text { SOM, } \\
\text { Microbial }\end{array}$ & \\
\hline & & & Winter & SOM & 0.14 & 0.0910 & 24.73 & $\begin{array}{c}\mathrm{C}: \mathrm{N}, \% \text { fines } \\
\text { SM, } \\
\text { Microbial } \\
\mathrm{C}: \mathrm{N}, \% \text { fines }\end{array}$ & \\
\hline & & \multirow[t]{2}{*}{ Portland } & Summer & $\begin{array}{c}\mathrm{SM}+ \\
\text { Microbial } \\
\mathrm{C}: \mathrm{N}\end{array}$ & 0.69 & 0.0004 & 22.58 & SOM, \% fines & $* * *$ \\
\hline & & & Winter & SOM & 0.35 & 0.012 & 31.81 & $\begin{array}{c}\text { SM, } \\
\text { Microbial } \\
\mathrm{C}: \mathrm{N}, \% \text { fines }\end{array}$ & $*$ \\
\hline \multirow[t]{4}{*}{ Nit } & \multirow{4}{*}{$\begin{array}{c}\text { SM, } \\
\text { SOM, } \\
\text { MBN, } \\
\mathrm{N}_{\min }, \\
\mathrm{NH}_{4}-\mathrm{N}, \\
\% \text { fines }\end{array}$} & \multirow[t]{2}{*}{ Baltimore } & Summer & $\begin{array}{l}\mathrm{N}_{\min }+\% \\
\text { fines }\end{array}$ & 0.28 & 0.057 & 56.36 & $\begin{array}{c}\mathrm{SM}, \mathrm{SOM}, \\
\mathrm{MBN}, \mathrm{NH}_{4}-\mathrm{N}\end{array}$ & \\
\hline & & & Winter & $\begin{array}{c}\mathrm{N}_{\min }+\mathrm{SOM} \\
+\mathrm{NH}_{4}-\mathrm{N}+ \\
\mathrm{SM}+ \\
\% \text { fines }\end{array}$ & 0.90 & $<0.0001$ & $\begin{array}{c}- \\
57.93\end{array}$ & $\mathrm{MBN}$ & $* * *$ \\
\hline & & \multirow[t]{2}{*}{ Portland } & Summer & $\begin{array}{c}\mathrm{MBN}+\mathrm{N}_{\min } \\
+\mathrm{NH}_{4}-\mathrm{N}+ \\
\mathrm{SM}+\mathrm{SOM}\end{array}$ & 0.76 & 0.0019 & 5.37 & $\%$ fines & $* *$ \\
\hline & & & Winter & $\begin{array}{c}\mathrm{N}_{\min }+\mathrm{NH}_{4-} \\
\mathrm{N}\end{array}$ & 0.99 & $<0.0001$ & 32.45 & $\begin{array}{c}\text { SM, MBN, } \\
\text { SOM, \% fines }\end{array}$ & $* * *$ \\
\hline \multirow[t]{4}{*}{ Resp } & \multirow{4}{*}{$\begin{array}{c}\text { SM, } \\
\text { SOM, } \\
\text { MBC, } \\
\% \text { fines }\end{array}$} & \multirow[t]{2}{*}{ Baltimore } & Summer & $\begin{array}{c}\text { SOM }+\mathrm{SM} \\
+ \\
\% \text { fines }\end{array}$ & 0.90 & $<0.0001$ & 65.87 & $\mathrm{MBC}$ & $* * *$ \\
\hline & & & Winter & $\mathrm{SM}+\mathrm{MBC}$ & 0.83 & $<0.0001$ & 75.1 & SOM, $\%$ fines & $* * *$ \\
\hline & & \multirow[t]{2}{*}{ Portland } & Summer & $\begin{array}{c}\mathrm{MBC}+\mathrm{SM} \\
+\mathrm{SOM}+\% \\
\text { fines }\end{array}$ & 0.95 & $<0.0001$ & 85.44 & - & $* * *$ \\
\hline & & & Winter & $\begin{array}{c}\mathrm{MBC}+\mathrm{SM} \\
+\% \text { fines }\end{array}$ & 0.73 & 0.0005 & 76.48 & SOM & $* * *$ \\
\hline
\end{tabular}

